\title{
Chronological narrative of the 1969-71 Mauna Ulu eruption of Kilauea Volcano, Hawaii
}

GEOLOGICALSURVEY PROFESSIONALPAPER 1056
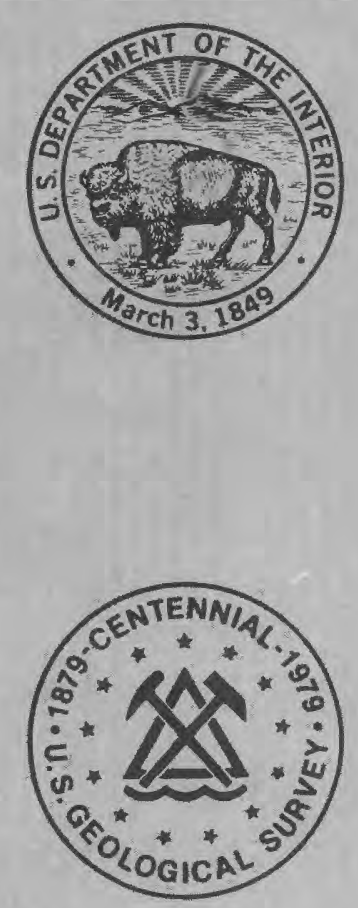
CHRONOLOGICAL NARRATIVE OF THE 1969-71 MAUNA ULU ERUPTION OF KILAUEA VOLCANO, HAWAII 


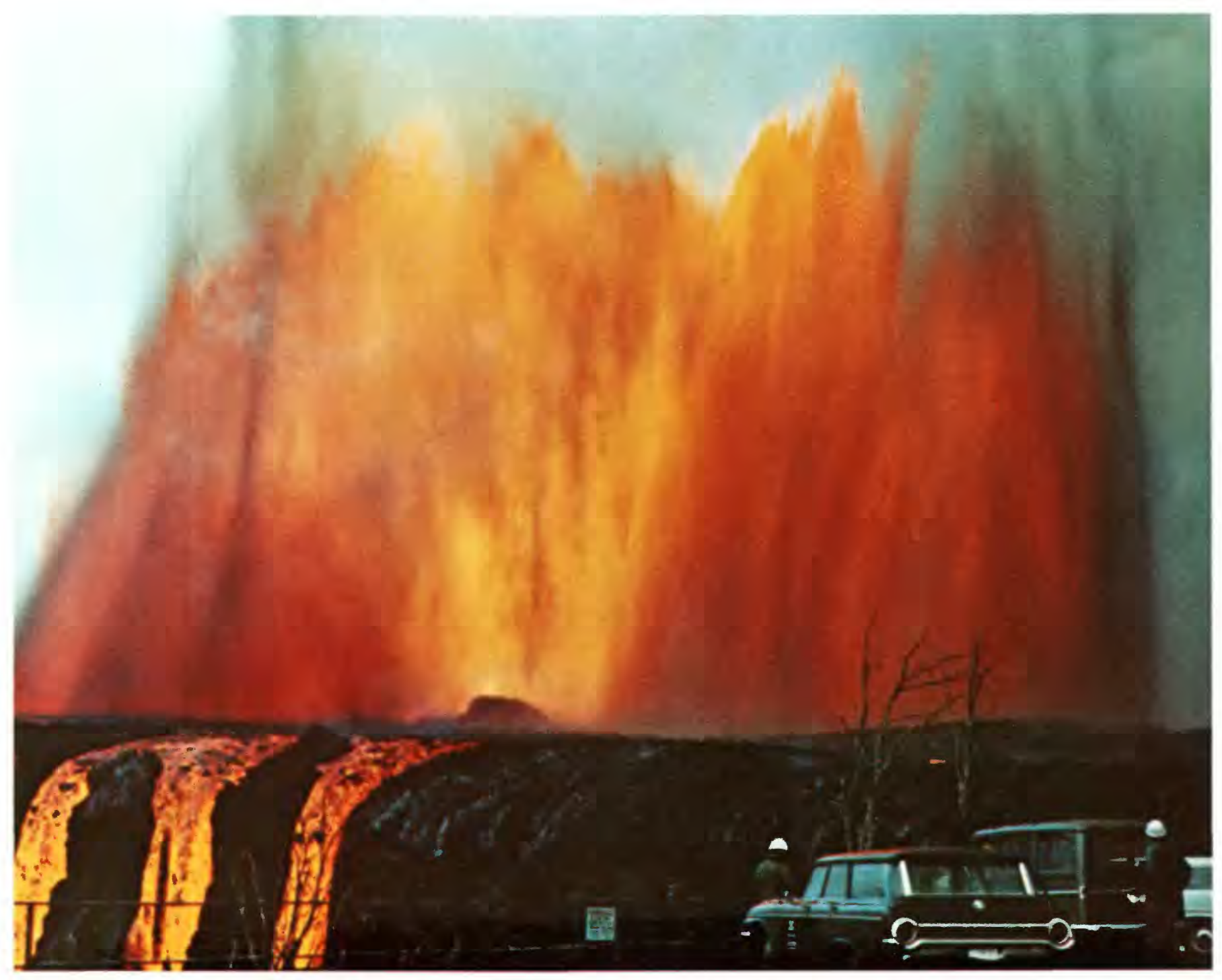

Lava fountain $300 \mathrm{~m}$ high plays from Mauna Ulu vent area on east rift zone of Kilauea Volcano, 1510 December 30, 1969. Lava flows fed by fountain cascade into Aloi Crater, $600 \mathrm{~m}$ from vent. Flow into Aloi was more vigorous before a dam near vent area diverted most of lava southward. Hot lava fountaining upward is yellow; cooler lava falling back to ground is orange and dark gray. Foun-

tain is widest of eruption and, as color pattern shows, appears to fan outward from vent. This was the last major fountain of the 1969-71 Mauna Ulu eruption. Scientists of the Hawaiian Volcano Observatory remain close to vehicles in case wind should shift and send fallout westward into observation area. 


\section{Chronological narrative of the 1969-71 Mauna Ulu eruption of Kilauea Volcano, Hawaii}

By DONALD A. SWANSON, WENDELL A. DUFFIELD, DALLAS B. JACKSON, and DONALD W. PETERSON

GE O L O G I A L S UR VEY PROFES I O N A L P A P E R 1056

Description of the longest, most voluminous, and most varied flank eruption in Kilauea's recorded history

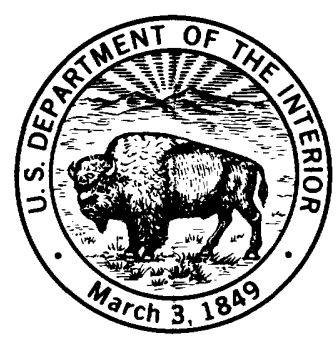


UNITED STATES DEPARTMENT OF THE INTERIOR

CECIL D. ANDRUS, Secretary

\section{GEOLOGICAL SURVEY}

H. William Menard, Director

Library of Congress catalog-card No. 78-600154

For sale by the Superintendent of Documents, U.S. Government Printing Office Washington, D.C. 20402

Stock Number 024-001-03136-1 


\section{CONTENTS}

\begin{tabular}{|c|c|}
\hline Pag & \\
\hline 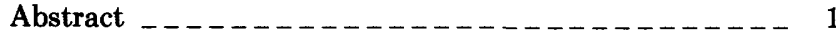 & First stage of eruption-Continued \\
\hline atroduction & October 14-19, 1969 \\
\hline cknowledgments & October 20, 1969 \\
\hline vents before the eruption & October 21-December 28,1969 \\
\hline ummary of eruption & December 29-30, 1969 \\
\hline irst stage of eruption & Second stage of eruption \\
\hline May 24-26, 1969 & December 31, 1969-April 8, 1970 \\
\hline May 27-June 11, $1969 \ldots \ldots$ & April 9-May 14, $1970 \ldots$ \\
\hline 1969 & May 15-July 5, $1970 \ldots \ldots$ \\
\hline dy $6,1969 \ldots \ldots$ & Third stage of eruption \\
\hline$-14,1969 \ldots \ldots \ldots \ldots \ldots \ldots-16$ & $1970-------------------$ \\
\hline $1969 \ldots \ldots \ldots \ldots \ldots \ldots \ldots \ldots$ & ber $27,1970 \ldots \ldots-\ldots \ldots$ \\
\hline y 20-August $2,1969 \ldots \ldots \ldots \ldots$ & -November $18,1970 \quad \ldots \ldots \ldots$ \\
\hline August $3-4,1969 \ldots \ldots \ldots$ & -December $24,1970 \ldots \ldots$ \\
\hline August $5-6,1969$ & $25,1970-$ January $27,1971 \ldots \ldots$ \\
\hline August $7-21,1969 \ldots \ldots \ldots$ & 28-February 20, $1971 \ldots \ldots \ldots$ \\
\hline gust 22,1969 & February 21-June 14, 1971 \\
\hline 23-September 5, 1969 & Fourth stage of eruption \\
\hline aber $6-7,1969$ & 15-October $15,1971 \ldots \ldots$ \\
\hline er 8 -October 9,1969 & the eruption \\
\hline October $10-13,1969 \ldots \ldots$ & 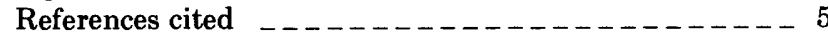 \\
\hline
\end{tabular}

\section{ILLUSTRATIONS}

[Plates in pocket]

FrontisPiECE. Lava fountains $300 \mathrm{~m}$ above Mauna Ulu vent area, December $30,1969$.

PLATE 1. Map of upper and middle east rift zone of Kilauea Volcano, showing vent fissures for eruptions between 1961 and 1971.

2. Summary of tilt, daily number of earthquakes, and important volcanic events during 1969-71 Mauna Ulu eruption.

3. Map showing sequential development of field of lava flows produced during 1969-71 Mauna Ulu eruption.

4. Maps showing changes in configuration and location of vents at Mauna Ulu, July 1970 to June 1971.

FIGURE 1. Index map of Kilauea Volcano

2. Graph showing tilt at Uwekahuna vault and horizontal strain across Kilauea Caldera, February 1969-October 1971 _.

3. Map showing location of five geodimeter lines across Kilauea Caldera

4. Map showing area covered by lava flows of 1969-71 Mauna Ulu eruption

5-9. Graphs showing:

5. Maximum fountain height compared with average eruption rate during first stage of 1969-71 Mauna Ulu eruption

6. Rate of growth in height of Mauna Ulu, May 1969-June 1970

7. Decline of level of lava lake in Mauna Ulu's summit crater, May-October 1971

8. Increase with time in cumulative volume of lava produced by the 1969-71 Mauna Ulu eruption

9-39. Photographs showing:

9. Lava flow covering Ainahou Road, May 1969

10. Lava fountains from eastern and western areas, May 28,1969

11. Craggy spatter rampart, June 14, 1969

12. Basin surrounding western vent area, June 14,1969

13. Two fountains more than $200 \mathrm{~m}$ high, June 26, 1969

14. Lava cascading over Holei Pali, June 26, 1969

15. Flows erupted on June 25-26, 1969 covering Chain of Craters Road

16. Man collecting lava from flow emptying from spatter cone, August 5,1969

17. Fifteen-m-high fountain feeding flow draining back underground, August 15, 1969

18. Partly filled Alae Crater and lava drapery on west rim, August 24, 1969

19. Partly drained lava lake in eastern vent basin, August 24,1969 . 
FIGURE 20. Tephra ridge extending south-southwest from vent area, August 30, 1969

21. Bark stripped off tree by falling pumice, August 30,1969

22. Newly formed western and eastern compartments in the western vent, August 24, 1969

23. Lava flow in graben east of Alae Crater, September 8, 1969

24. Aerial view of Mauna Ulu vent area, September 24, 1969

25. Irregular profile of tephra mound on September 8, 1969

26. Piece of reticulite caught in tree downwind from vent area

27. Eastern compartment of vent area, September 28, 1969

28. Dome fountain, October 11, 1969

29. Slump scars in welded spatter on flank of Puu Huluhulu, November 1969

30. Final minutes of fountaining at vent area, October 20,1969

31. Crusted pool of lava in eastern compartment, November $9,19 \overline{6} \overline{9}$

32. Sequence of drainback and refilling of eastern compartment, November 13, 1969

33. Drainback at vent area, December 29, 1969

34. Lava falls into Aloi Crater, December 30, 1969

35. Tilted slabs of welded spatter blanketed by pumice and spatter erupted mainly on December 30,1969

36. Puddle of lava nearing display case at Aloi Crater, April 9, $1970 \ldots$

37. Lava flow spilling from Aloi Crater and covering Chain of Craters Road, April 9, $1970 \ldots \ldots$

38. Aerial view of Mauna Ulu vent area, May 9, 1970

39. Driblet spires in Aloi Crater formed on May 21, 1970

40. Photograph of Mauna Ulu shield from top of Puu Huluhulu, June 20, $1970 \ldots$

41. Tracings from photographs showing profiles of Mauna Ulu as seen from Pauahi Crater, May 22, 1970 to midJune 1971

42-51. Photographs showing:

42. Man sampling lava through skylight in lava tube, September 1970

43. Burning asphalt as lava flow crosses Chain of Craters Road, August 15,1970

44. Skylight in lava tube $100 \mathrm{~m}$ southeast of Alae Crater, November 5, $1970 \ldots$

45. Aerial view of subsidence bowl at Alae Crater and surrounding area, March 28, 1971

46. Aerial view of trench and summit crater of Mauna Ulu, May 25, 1971

47. Characteristics of trench on east flank of Mauna Ulu, June 28, 1971

48. Blunt east end of trench and field of lava flows farther east, June 28,1971

49. Man measuring depth to surface of lava lake with rangefinder, July 1971

50. Flat-topped ridge dividing Mauna Ulu lava lake into two pools, July 17,1971

51. East end of summit crater and dike, September 7, 1971

\section{TABLES}

TABLE 1. Papers dealing with aspects of the 1969-71 Mauna Ulu eruption

2. Motion pictures dealing wholly or largely with the 1969-71 Mauna Ulu eruption

3. Data for eruptions along east rift zone of Kilauea Volcano, 1961-71

4. Cumulative extensional strain for distances in summit strain monitor during two periods of inflation, Kilauea Volcano-

5. Summary of episodes of high or sustained fountaining during the 1969-71 Mauna Ulu eruption

6. Calculation of volume of 1969-71 Mauna Ulu lava 


\title{
CHRONOLOGICAL NARRATIVE OF THE 1969-71 MAUNA ULU ERUPTION OF KILAUEA VOLCANO, HAWAII
}

\author{
By Donald A. Swanson, Wendell A. Duffield, \\ Dallas B. Jackson, and Donald W. Peterson
}

\section{ABSTRACT}

The 1969-71 Mauna Ulu eruption on the upper east rift zone of Kilauea Volcano lasted from May 24, 1969 to October 15, 1971; it was the longest and most voluminous flank eruption at Kilauea during historic time. About $185 \times 10^{6} \mathrm{~m}^{3}$ of basaltic lava was erupted; the lava covered an area of approximately $50 \mathrm{~km}^{2}$ and built a parasitic shield $80 \mathrm{~m}$ high. The eruption can be divided into four stages, each of which was dominated by a particular pattern of behavior.

The first stage, May 24 to December 30, 1969, was characterized by episodes of high or sustained fountaining, each lasting from a few hours to about 3 days and interspersed with longer periods of weak activity. Most fountaining during this stage occurred in one general vent area located $600 \mathrm{~m}$ south-southeast of Puu Huluhulu, midway between two large pit craters (since filled), Aloi and Alae Craters. Fountains reached or exceeded $300 \mathrm{~m}$ in height during six of the episodes, once towering to a maximum of $540 \mathrm{~m}$. The fountains supplied lava to fast-moving voluminous flows that travelled as far as the coastline, $12 \mathrm{~km}$ from the vent. The flows ultimately filled Alae Crater and partly filled Aloi Crater. The periods of weak activity between episodes of strong fountaining lasted from a few days to several weeks, during which time lava splashed and circulated in the vent, sometimes forming low fountains, sometimes quietly upwelling and overflowing the vent. Cyclic rise and fall of the lava column characterized the periods of weak activity. This phenomenon, termed gas-piston activity, is apparently caused by the expansion and subsequent vigorous loss of gas from the column as the gas neared the surface.

The second stage, December 31,1969 to July 5, 1970, was marked by weak activity at the vent similar to that which characterized the periods between major fountains of the first stage. Lava from a new fissure that opened across Aloi Crater in April completed filling the crater. During this stage, particularly in late May and June, overflows of short duration from the main vent area built a shield, eventually $80 \mathrm{~m}$ high; it was at this time that Mauna Ulu ("growing mountain" in Hawaiian) received its name. Much of the activity during this stage was characterized by gas-piston cycles.

The third stage, July 6, 1970 to June 14, 1971, was marked by cessation of overflows from the main vent area and the opening of several vents along a new fissure on the east flank of the Mauna Ulu shield. Activity at the new vents was often dominated by gaspiston behavior, and overflows were common. The walls of the fissure at the summit of Mauna Ulu after progressively collapsing formed an ovoid crater within which an active lava lake circulated. Underground conduits from this lake probably supplied lava to the vents on the east flank of Mauna Ulu. Tubes carried lava from these vents into the crusted lava lake occupying Alae Crater, and an outlet tube transported lava from the lake and distributed it downslope. Much surface and tube-fed pahoehoe entered the ocean in September 1970 and March-May 1971. Beginning in October 1970, small craters formed around the individual vents on the east flank of Mauna Ulu. These craters enlarged by collapse and merged to form a continuous trench along the fissure by the spring of 1971. The trench ultimately intersected the east end of the summit crater. In late May, the vents on the east flank gradually stopped feeding lava to the reservoir in Alae Crater and the reservoir in turn, stopped supplying lava to the flows and tubes to the south.

The fourth stage, June 15 to October 15,1971 , was characterized by the slow decline and eventual cessation of eruptive activity. The surface of the lava lake in the summit crater progressively withdrew to lower levels, and circulation of lava grew increasingly sluggish. The end of the eruption was marked by the disappearance of visible lava beneath rubble on the floor of the crater.

The four stages of the eruption accompanied other important changes at Kilauea Volcano. Each stage was accompanied by harmonic tremor and a characteristic pattern of ground deformation in the summit area of Kilauea, $10 \mathrm{~km}$ west of Mauna Ulu. The first three stages (the fourth was not sampled) were typified by lava with chemistry that differed from one stage to the next. These patterns demonstrate a systematic relation between the eruptive behavior of Mauna Ulu and the more fundamental process of magma supply to the entire volcano.

Observations of the 1969-71 Mauna Ulu eruption provided a wealth of information regarding the development of parasitic shield volcanoes, the nature of the gas-piston process, the formation of lava tubes and their importance in carrying lava long distances, and a host of other processes not generally available for study during shorter eruptions. Consequently, the eruption must be considered one of the most important of all historic Kilauea eruptions.

\section{INTRODUCTION}

The longest-lived and most voluminous rift eruption in the recorded history of Kilauea Volcano began at 0445 May 24, 1969. For 21/2 years thereafter, observers were treated to a magnificent volcanic display that was unprecedented in its variety. At times, the heat from towering fountains of lava forced observers to cower behind barricades hundreds of meters away. At other times, the activity was so benign that one could peer directly into the vent, a seething cauldron 
of bubbling, red-hot lava. The varied nature of activity afforded members of the Hawaiian Volcano Observatory unparalleled opportunities to observe firsthand the complex growth and evolution of a parasitic shield volcano, Mauna Ulu.

The eruption is termed the 1969-71 Mauna Ulu eruption to distinguish it from other Kilauea eruptions in 1971 (August and September) and from later eruptions of Mauna Ulu in 1972-74 (Peterson and others, 1976).

Many papers have already been written dealing with specific aspects of the eruption (table 1), but they provide no broad overview of it. In this paper, we present a detailed chronological narrative of the entire eruption, summarizing as neccessary the pertinent observations of the previous papers. Several motion pictures consisting wholly or largely of scenes from the eruption (table 2 ) provide additional visual documentation.

TABLE 1.-Papers dealing with aspects of the 1969-71 Mauna Ulu eruption

\begin{tabular}{|c|c|}
\hline Topic & Refe \\
\hline General summary _- & $\begin{array}{l}\text { Swanson, Jackson, Duffield } \\
\text { and Peterson (1971); Peter- } \\
\text { son, Christiansen, Duffield, } \\
\text { Holcomb, and Tilling (1976). }\end{array}$ \\
\hline Lava chemistry & 5). Swanson, and Duffield \\
\hline Lava tubes _ - & $\begin{array}{l}\text { Peterson and Swanson (1974); } \\
\text { Cruiks hank and Wood } \\
\text { (1972); Greeley }(1971,1972) \text {. }\end{array}$ \\
\hline Pahoehoe flows & $\begin{array}{l}\text { Swanson (1973); Schmincke } \\
\text { (1971). }\end{array}$ \\
\hline Alae Crater, filling & $\begin{array}{l}\text { on, Duffield, Jackson, } \\
\text { Peterson (1972). }\end{array}$ \\
\hline rtial dra & (1972) \\
\hline lu lava lake & Duf \\
\hline May 1970 intrusive event & wan- \\
\hline Magma supply rate $\ldots \ldots \ldots$ & Swe \\
\hline Volcanomagnetic effect & ld, and Sta- \\
\hline $\begin{array}{l}\text { Detection of lava in tubes using } \\
\text { geophysical methods }\end{array}$ & $\begin{array}{l}\text { on, Jackson, and Frisch- } \\
\text { t (1971). }\end{array}$ \\
\hline Lava delta $\ldots \ldots$ & $\begin{array}{l}\text { Moore, Phillips, Grigg, Peter- } \\
\text { son and Swanson (1973); Pe- } \\
\text { terson (1976). }\end{array}$ \\
\hline g - - & Crist \\
\hline $\begin{array}{l}\text { Volatile loss during eruption } \\
\text { and lava flow }\end{array}$ & Swanson and Fabbi (1973). \\
\hline Pele's hair _ $\ldots \ldots$ & $\begin{array}{l}\text { Duffield, Heiken, and Gibson } \\
\text { (1974). }\end{array}$ \\
\hline Pele's tears & $w(197$ \\
\hline Volcanic flames & ton (1973). \\
\hline Gas chemistry _- & $\begin{array}{l}\text { Naughton, Lee, Keeling, Fin- } \\
\text { laysen and Dority (1973). }\end{array}$ \\
\hline ne sublimates & $\begin{array}{l}\text { Naughton, Lewis, Hammond } \\
\text { and Nishimoto (1974); } \\
\text { Naughton, Greenberg, and } \\
\text { Goguel (1976). }\end{array}$ \\
\hline Volcanic landforms & $\begin{array}{l}\text { Holcomb, Peterson, and Tilling } \\
\text { (1974). }\end{array}$ \\
\hline
\end{tabular}

TABLE 2.-Motion pictures dealing wholly or largely with the 1969-71 Mauna Ulu eruption.

\begin{tabular}{|c|c|c|}
\hline Name & Producer & Subject \\
\hline $\begin{array}{l}\text { Heartbeat of } \\
\text { a volcano }\end{array}$ & $\begin{array}{l}\text { Encyclopedia Britannica } \\
\text { Educational Corporation, } \\
\text { Chicago. }\end{array}$ & $\begin{array}{l}\text { General eruptive activity } \\
\text { and how volcanologists } \\
\text { monitor it. }\end{array}$ \\
\hline Fire Mountain _- & do. & $\begin{array}{l}\text { Eruption scenes artfully } \\
\text { coordinated with music } \\
\text { (no narration). }\end{array}$ \\
\hline $\begin{array}{l}\text { Fire under } \\
\text { the sea }\end{array}$ & $\begin{array}{l}\text { Lee Tepley, } \\
\text { Moonlight Productions } \\
2650 \text { California St., }\end{array}$ & $\begin{array}{l}\text { Lava movement under } \\
\text { water; } \\
\text { pillow formation. }\end{array}$ \\
\hline $\begin{array}{l}\text { Mauna Ulu plate } \\
\text { tectonics }\end{array}$ & $\begin{array}{l}\text { W. A. Duffield (U.S. } \\
\text { Geological Survey) } \\
\text { Menlo Park, CA., } 94025 .\end{array}$ & $\begin{array}{l}\text { Movement of crust of } \\
\text { lava lake. }\end{array}$ \\
\hline
\end{tabular}

The eruption took place along part of the upper east rift zone of Kilauea (fig. 1), where much volcanic activity had occurred during the preceding eight years (table 3 ; pl. 1). The line of eruptive fissures between Aloi and Alae Craters, where most of the 1969-71 activity occurred, crosses at a small angle the trace of the December 1965 fissure system; principal vents of Mauna Ulu are less than $100 \mathrm{~m}$ south of the December 1962 fissure (pl. 1; Moore and Krivoy, 1964; Fiske and Koyanagi, 1968). Fumarolic activity, which had characterized this general area since the early 1960's, increased after the December 1965 eruption and formed thick deposits of sulfurous sublimates along ground

TABLE 3.-Data for eruptions along east rift zone of Kilauea Volcano, 1961-1971

[See plate 1 for precise locations]

\begin{tabular}{|c|c|c|c|c|}
\hline Date & Locality & $\begin{array}{l}\text { Volume } \\
\text { of lava } \\
\left(10^{6} \mathrm{~m}^{3}\right)\end{array}$ & $\begin{array}{c}\text { Area } \\
\text { covered } \\
\text { by lava } \\
\left(\mathrm{km}^{2}\right)\end{array}$ & Reference \\
\hline 1961 & & & & \\
\hline Sept. $22-25$ & $\begin{array}{l}\text { Near Napau Crater } \\
\text { and } 22 \mathrm{~km} \text { eastward }\end{array}$ & 1.39 & 0.76 & $\begin{array}{l}\text { Richter, Ault, Eaton, } \\
\text { and Moore(1964). }\end{array}$ \\
\hline $\begin{array}{l}1962 \\
\text { Dec. 7-9 }\end{array}$ & $\begin{array}{l}\text { Aloi Crater to Kane } \\
\text { Nui o Hamo }\end{array}$ & .12 & .08 & $\begin{array}{l}\text { Moore and Krivoy } \\
\text { (1964). }\end{array}$ \\
\hline $\begin{array}{l}1963 \\
\text { Aug. 21-23 }\end{array}$ & $\begin{array}{l}\text { In and near Alae } \\
\text { Crater }\end{array}$ & .63 & .07 & $\begin{array}{l}\text { Peck, Wright, and } \\
\text { Moore(1966). }\end{array}$ \\
\hline $\begin{array}{l}1963 \\
\text { Oct. 5-6 }\end{array}$ & $\begin{array}{l}\text { Between Napau Crater } \\
\text { and Kalalua Cone }\end{array}$ & 6.8 & 3.3 & $\begin{array}{l}\text { Moore and Koyanagi } \\
\text { (1969). }\end{array}$ \\
\hline $\begin{array}{l}1965 \\
\text { Mar. 5-15 }\end{array}$ & $\begin{array}{l}\text { Makaopuhi Crater to } \\
\text { Kalalua Cone }\end{array}$ & 15.2 & 7.05 & $\begin{array}{l}\text { Wright, Kinoshita, and } \\
\text { Peck(1968). }\end{array}$ \\
\hline $\begin{array}{l}1965 \\
\text { Dec. } 24-25\end{array}$ & $\begin{array}{l}\text { Aloi Crater to Kane } \\
\text { Nui o Hamo }\end{array}$ & .59 & .63 & $\begin{array}{l}\text { Fiske and Koyanagi } \\
\text { (1968). }\end{array}$ \\
\hline $\begin{array}{l}1968 \\
\text { Aug. } 22-26\end{array}$ & $\begin{array}{l}\text { Hiiaka Crater and } \\
20 \mathrm{~km} \text { eastward }\end{array}$ & .014 & .02 & $\begin{array}{l}\text { Jackson, Swanson, } \\
\text { Koyanagi, and } \\
\text { Wright(1975). }\end{array}$ \\
\hline $\begin{array}{l}1968 \\
\text { Oct. } 7-22\end{array}$ & $\begin{array}{l}\text { Napau Crater and } \\
6 \mathrm{~km} \text { eastward } \\
\text { and westward }\end{array}$ & 7.5 & 3.5 & 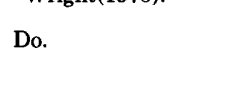 \\
\hline $\begin{array}{l}1969 \\
\text { Feb. } 22-28\end{array}$ & $\begin{array}{l}\text { Near Aloi Crater and } \\
11 \mathrm{~km} \text { eastward }\end{array}$ & 20 & 6 & $\begin{array}{l}\text { Swanson, Jackson, } \\
\text { Koyanagi, and } \\
\text { Wright(1976). }\end{array}$ \\
\hline $\begin{array}{l}1969 \\
\text { May 24- } \\
1971 \\
\text { Oct. } 15\end{array}$ & $\begin{array}{l}\text { Mauna Ulu (between } \\
\text { Aloi and Alae } \\
\text { Craters) and } \\
\text { vicinity }\end{array}$ & 185 & 50 & This paper. \\
\hline
\end{tabular}

'Includes only volume remaining on surface. Does not include volume of lava that drained back into fissures before eruption ended. 


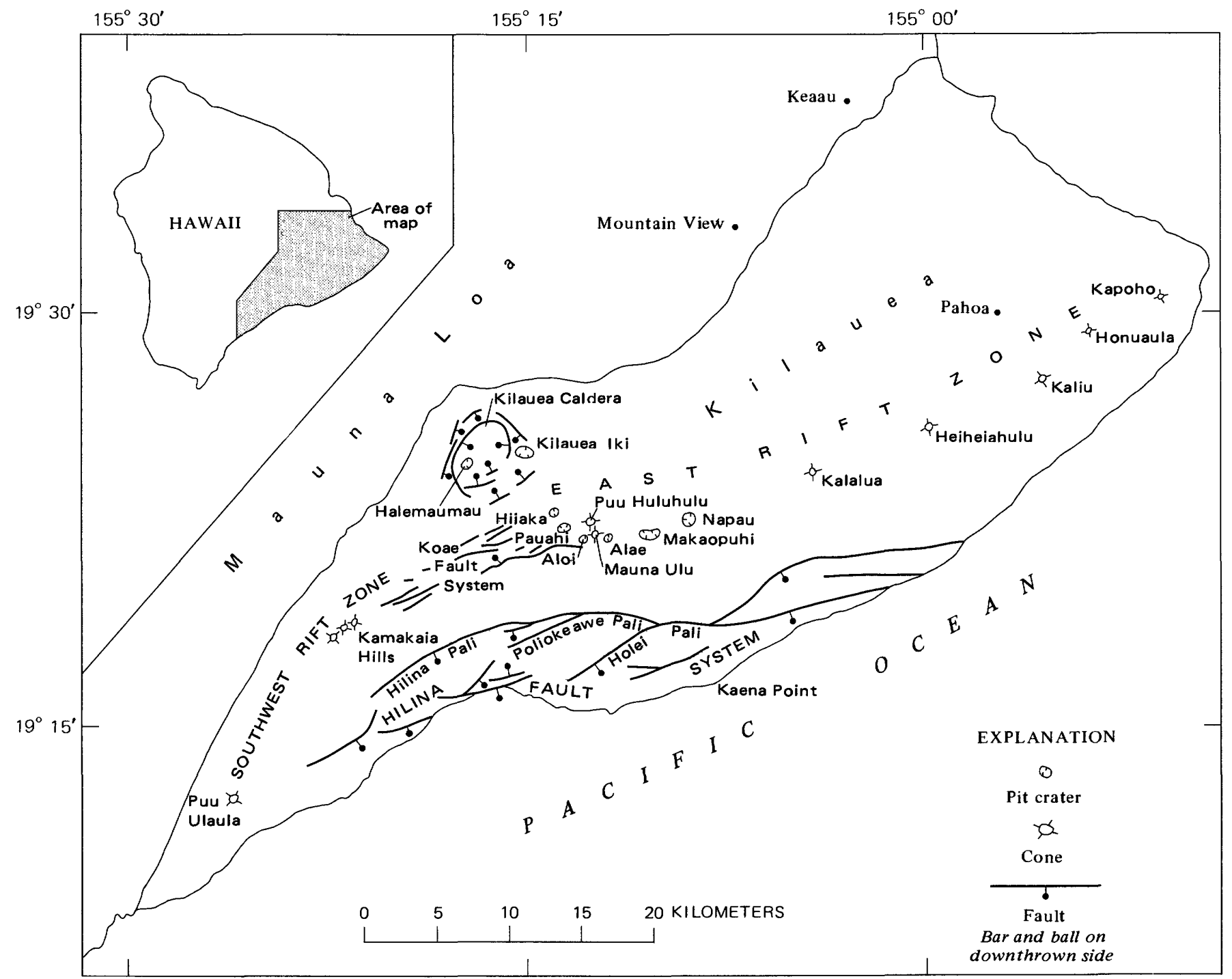

FIGURE 1.-Kilauea Volcano, showing rift zones, fault systems, and localities mentioned in text. Aloi and Alae Craters have been buried by flows from Mauna Ulu. The subaerial part of the east rift zone is loosely divided into three parts: the upper part extends from the summit caldera to Makaopuhi Crater; the middle part, from Makaopuhi to Heiheiahulu; the lower part, northeastward from Heiheiahulu to the seacoast.

cracks and former vents. Other eruptions occurred within $1 \mathrm{~km}$ of the Mauna Ulu area in August 1963 (Peck and others, 1966) and February 1969 (Swanson, Jackson, Koyanagi, and Wright, 1976), only three months before the 1969-71 Mauna Ulu eruption began.

Throughout the 1960's, the area centered around Aloi and Alae Craters was the western limit of volcanic activity on the rift zone, except for a small eruption in and near Hiiaka Crater (pl. 1) in 1968 (Jackson and others, 1975). Much activity took place farther east (downrift), however (see pl. 1; Moore and Koyanagi, 1969, pl. 1; Swanson, Jackson, Koyanagi, and Wright, 1976, pl. 1).

The Aloi-Alae area occupies an important structur- al location at the southeast end of the area where the Koae fault system and the east rift zone intersect (fig. 1). This area of intersection is doubtless complex at depth, magma conduits extend southeast from the summit caldera crossing and interact with east-northeast-trending fractures of the Koae system (Swanson, Duffield, and Fiske, 1976; Duffield, 1975). Such structural complexity may facilitate temporary blockages in magma conduits connecting with the summit reservoir, leading to temporary storage, increased magmatic pressure, and eruption uprift from the blockage. In their discussion, Swanson, Jackson, Koyanagi, and Wright (1976) relate this theme to the origin of magma reservoirs and pit craters along the upper east rift zone. 


\section{ACKNOWLEDGMENTS}

Scores of individuals, from long-time personnel of the Hawaiian Volcano Observatory to mainland tourists on their Hawaiian holiday, contributed the observations that make this narrative rather complete despite the long duration and complicated nature of the eruption. It is impossible to single out all these friends, but we hope they realize how important their observations were and how grateful we are for them. Personnel of Hawaii Volcanoes National Park made particularly valuable contributions in many ways, and without their assistance, our job would have been much more difficult. We take special pleasure in expressing gratitude to three foreign geologists who had long visits at Kilauea during the eruption and contributed ideas, helpful observations, and strong backs: Drs. Renato Cristofolini (Catania, Italy), Kazuaki Nakamura (Tokyo), and Hans-Ulrich Schmincke (Bochum, West Germany). Two astronomers from the University of Hawaii, Dale Cruikshank and David Morrison, lowered their sights but retained keen observational abilities, repeatedly applying them to Mauna Ulu in 1970-71. Finally, we thank H. A. Powers, scientist-in-charge of the observatory until August 1970, and T. L. Wright, on the staff until midAugust 1969, for advice, field assistance, and ideas.

\section{EVENTS BEFORE THE ERUPTION}

The 1969-71 Mauna Ulu eruption was only one in a series of Kilauea eruptions that began in November 1967 and continued through December 1974. The November 1967-July 1968 eruption (Kinoshita and others, 1969) was confined to Halemaumau Crater in Kilauea's summit caldera (fig. 1). Thereafter, activity shifted to the upper and middle parts of the east rift zone, with eruptions in August and October 1968 (Jackson and others, 1975) and February 1969 (Swanson, Jackson, Koyanagi, and Wright, 1976). Each rift eruption was larger than its predecessor; the February 1969 eruption, with a volume of lava of $20 \times 10^{6} \mathrm{~m}^{3}$, was probably the largest historic rift eruption at Kilauea prior to the 1969-71 Mauna Ulu eruption.

The summit area of Kilauea began swelling even before the end of the February eruption and continued to swell at a nearly constant rate until the Mauna Ulu eruption began (fig. 2). By May 10, summit strain had reached about the same level as just before the February eruption (table 4; fig. 3 ). On this basis, we anticipated an eruption in the near future, and on May 21 a staff meeting was held to plan our course of study when the eruption began.

Along with the greater strains, seismic activity in the upper east rift and summit areas increased episodically several days before the eruption (pl. $2 B$ and $C$ ).

\section{SUMMARY OF ERUPTION}

The 1969-71 Mauna Ulu eruption lasted almost 29 months, from May 24, 1969 to October 15, 1971; the end of the eruption is taken arbitrarily as the last date on which lava was seen in the vent. About $185 \times 10^{6} \mathrm{~m}^{3}$ of basaltic lava was erupted from a 4-km-long set of fissures centered at a vent area between Alae and Aloi Craters (since buried), where most activity took place and where a large parasitic shield, Mauna Ulu ("growing mountain" in Hawaiian), was built. Lava flows that erupted from this set of fissures eventually covered an area of approximately $50 \mathrm{~km}^{2}$ (fig. 4). In addition, a small volume of lava was erupted in August 1969 from a fissure 7-8 $\mathrm{km}$ downrift from Mauna Ulu. During the eruption, magma was supplied to the highlevel storage complex with Kilauea at a rate of about 3 $\times 10^{5} \mathrm{~m}^{3} /$ day (about $0.1 \mathrm{~km}^{3} / \mathrm{yr}$ ); some of this magma was erupted to the surface, and some remained underground (Swanson, 1972).

The eruption can be divided into four stages (pl. 2; fig. 3) on the basis of the type of activity. The first stage, ending on December 30,1969, was characterized by 12 short-lived ( $4^{1 / 2} \mathrm{hrs}-3$ days) episodes of high or sustained fountaining separated by periods of weaker activity a few days to several weeks long. Six episodes of the first stage produced lava fountains $300 \mathrm{~m}$ or more in height, and one fountain was $540 \mathrm{~m}$ high. Fountain height correlated roughly with the rate of

FIGURE 2.-Summary of ground tilt and horizontal strain in summit area of Kilauea Volcano before and during the 1969-71 Mauna Ulu eruption. $A$, Ground tilt. East-west and northsouth components of tilt measured with short-base water-tube tiltmeter in Uwekahuna vault (UWE in inset map in $B$ ). $B$, Horizontal strain. Extension and extensional strain for geodimeter line across Kilauea Caldera between stations HVO 113 and HVO 10 (inset). Vertical bars, periods of strongest or unusual eruptive activity during the 1969-71 eruption. Eruptions also took place in late February 1969 (Swanson, Jackson, Koyanagi, and Wright, 1976) and in mid-August and late September 1971 (Peterson and others, 1976); all three of these brief eruptions were accompanied by marked changes in ground $\operatorname{tilt}(A)$ and horizontal strain $(B)$. 


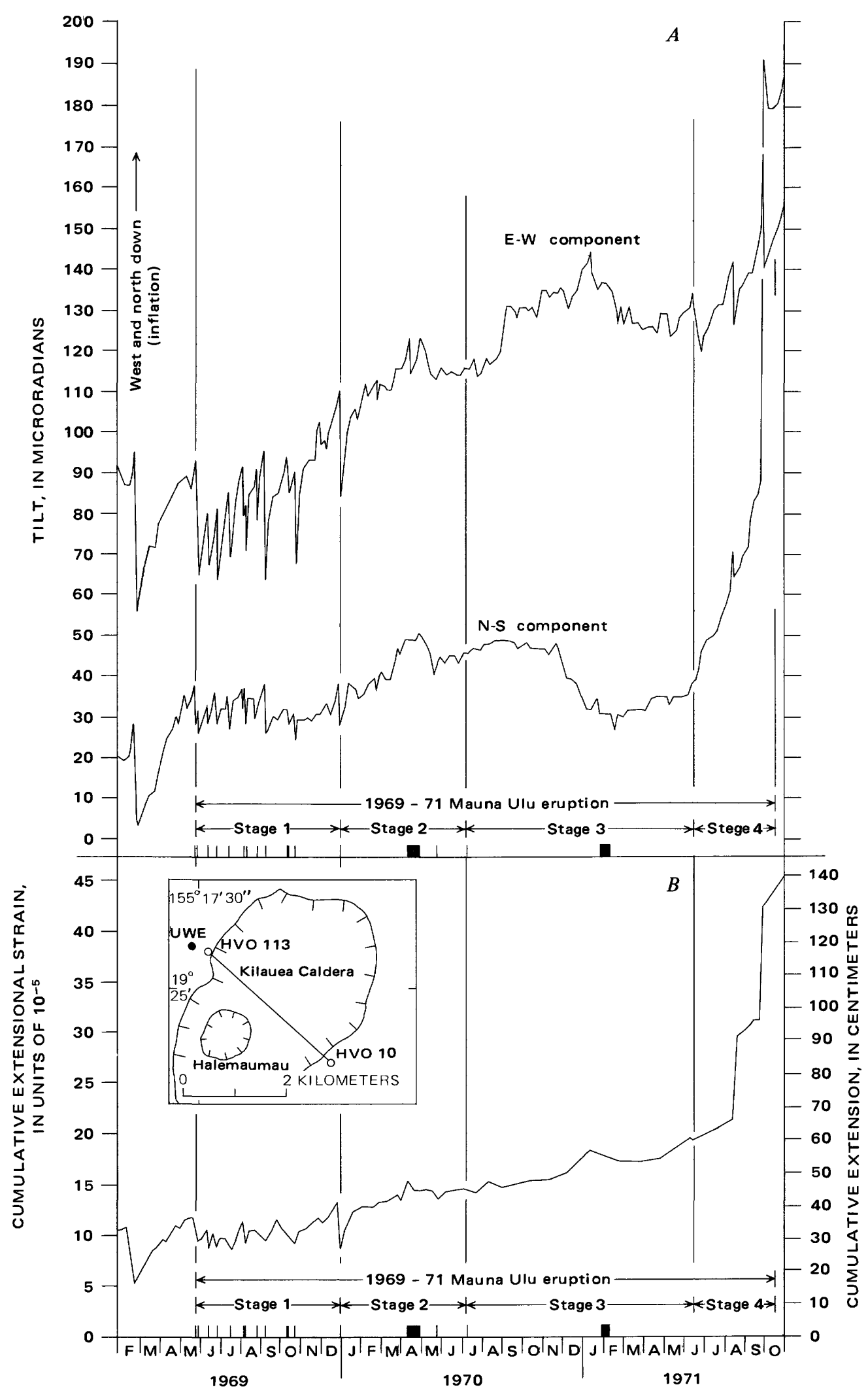


TABLE 4.-Cumulative extensional strain for distances in summit strain monitor during two periods of inflation, Kilauea Volcano ${ }^{1}$

\begin{tabular}{|c|c|c|c|}
\hline \multirow{2}{*}{$\underset{\text { line }^{2}}{\text { Geodimeter }}$} & \multirow{2}{*}{$\begin{array}{l}\text { Approximate } \\
\text { length }(m)\end{array}$} & \multicolumn{2}{|c|}{$\begin{array}{c}\text { Cumulative extensional strain } \\
\text { (units of } 10^{-5} \text { ) }\end{array}$} \\
\hline & & $\begin{array}{l}12 \text { Oct. } 1968- \\
12 \text { Feb. } 1969 \\
\end{array}$ & $\begin{array}{c}24 \mathrm{Feb}- \\
20 \text { May } 1969 \\
\end{array}$ \\
\hline HVO 113-HVO 10 & --3097 & 6.56 & 6.83 \\
\hline HVO 119-HVO 10 & --2893 & 4.94 & 4.80 \\
\hline HVO 113-HVO 114 & --5128 & 4.74 & 5.23 \\
\hline HVO 119-HVO 114 & --3070 & 5.15 & 5.18 \\
\hline HVO 119-HVO 113 & --3155 & 4.75 & 4.12 \\
\hline
\end{tabular}

'From Swanson, Jackson, Koyanagi, and Wright (1976) ${ }^{2}$ See figure 3 for location of measured lines.

${ }^{3}$ Relative to assumed zero strain at start of each period of inflation.

Determined by comparing geodimeter measurements at different times and dividing the change in length by the initial length of the line.

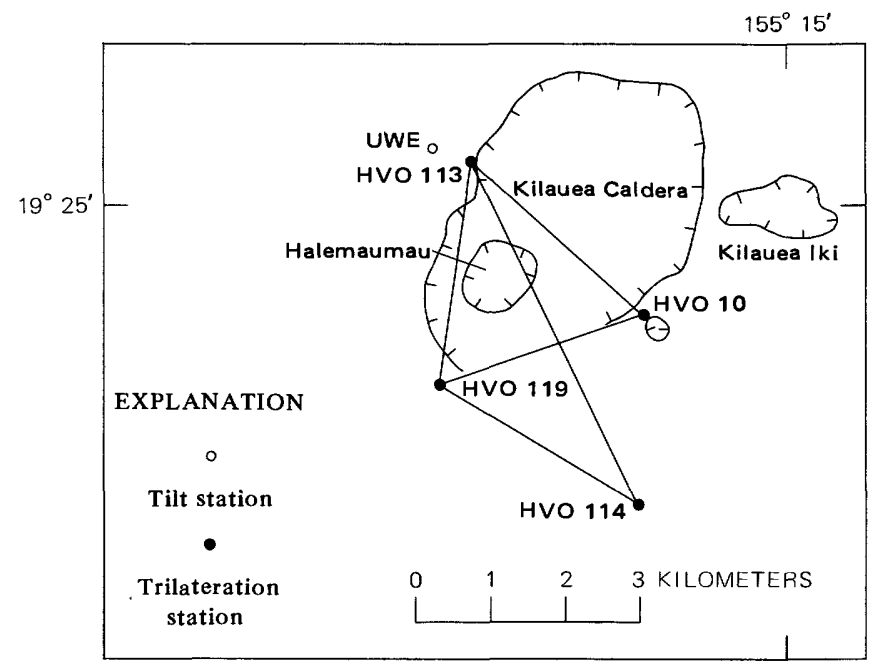

FIGURE 3.-Locations of Uwekahuna (UWE) vault containing short-base water-tube tiltmeter and trilateration stations used in determining the level of summit strain. See figure 2 and table 4 .

eruption (fig. 5A), which ranged from 0.05 to $1.45 \times$ $10^{6} \mathrm{~m}^{3} / \mathrm{hr}$ for the 12 episodes (table 5). The total volume of lava produced during short-lived episodes generally varied directly with eruption rate (fig. $5 B$ ), consistent with model (Shaw and Swanson, 1970) and empirical (Walker, 1973) studies. A large mound of partly welded spatter and pumice was built downwind of the vent area. Lava flows fed by the fountains filled Alae Crater, which subsequently drained and then was quickly refilled (Swanson and others, 1972); lava also partly filled Aloi Crater. Flows advanced far to the south, and one flow entered the ocean $12 \mathrm{~km}$ away.

Periods of weak activity between episodes of strong fountaining were typified by the presence of an observable lava column within the Mauna Ulu vent. Numerous small flows were fed by the lava column when it rose high enough to spill out of the vent. Short-lived spatter cones were formed from time to time. A cyclic rise and fall of the lava column, termed gas-piston activity, was often observed. During such cycles, the lava column, capped by a solidified but flexible crust, first rose quietly a distance of a few meters to several tens of meters in 15-20 minutes. No spattering accompanied this rise. The column either continued its slow rise until the next stage began or stopped rising a short time before the next part of the cycle began. The next part of the cycle was violent. Suddenly, vigorous bubbling within the column generated intense spattering, the crust was torn to shreds, and the column withdrew turbulently to its starting level. The time from the onset of bubbling to the completion of withdrawal was generally a minute or two. This type of activity is ascribed to uplift of the column by expanding gases trapped beneath a relatively impermeable crust; eventually gas pressure overcame the strength of the crust, degassing of the column quickly resulted, and the lava withdrew to fill the void evacuated by the lost gas.

The second stage of the eruption, December 31 , 1969 to July 5,1970 , was marked by weak activity and no major fountaining episodes. The lava column was visible deep within the main vent for most of the time. Occasionally, however, it rose to the surface and spilled out as thin flows that added to the height of Mauna Ulu (fig. 6). Hundreds of such flows were erupted in five major pulses during a major period of growth at Mauna Ulu between late May and the end of June. Mauna Ulu broadened and nearly doubled its height between January and July to become a prominent shieldlike edifice standing $80 \mathrm{~m}$ above its base. This was the last period in which the height of Mauna Ulu increased during the eruption. Throughout the first two stages of the eruption, the height of the shield increased episodically but at a nearly linear rate of about $6 \mathrm{~m}$ per month, if averaged over periods of several weeks (fig. 6). The rate of volume increase with time could not be calculated owing to inadequate data on the shape of the shield, which grew asymmetrically. After June 1970, lava outpourings were confined to fissures on the flanks of Mauna Ulu and beyond its base; only during Mauna Ulu's later eruptions in 1972-1974 did its height again increase (Peterson and others, 1976).

A new fissure opened across Aloi Crater on April 9, 1970 and erupted lava that eventually filled the crater. This activity continued until April 29. On May 15-16, a swarm of earthquakes (pl. $2 B$ and $C$; Endo, 1971) ac- 


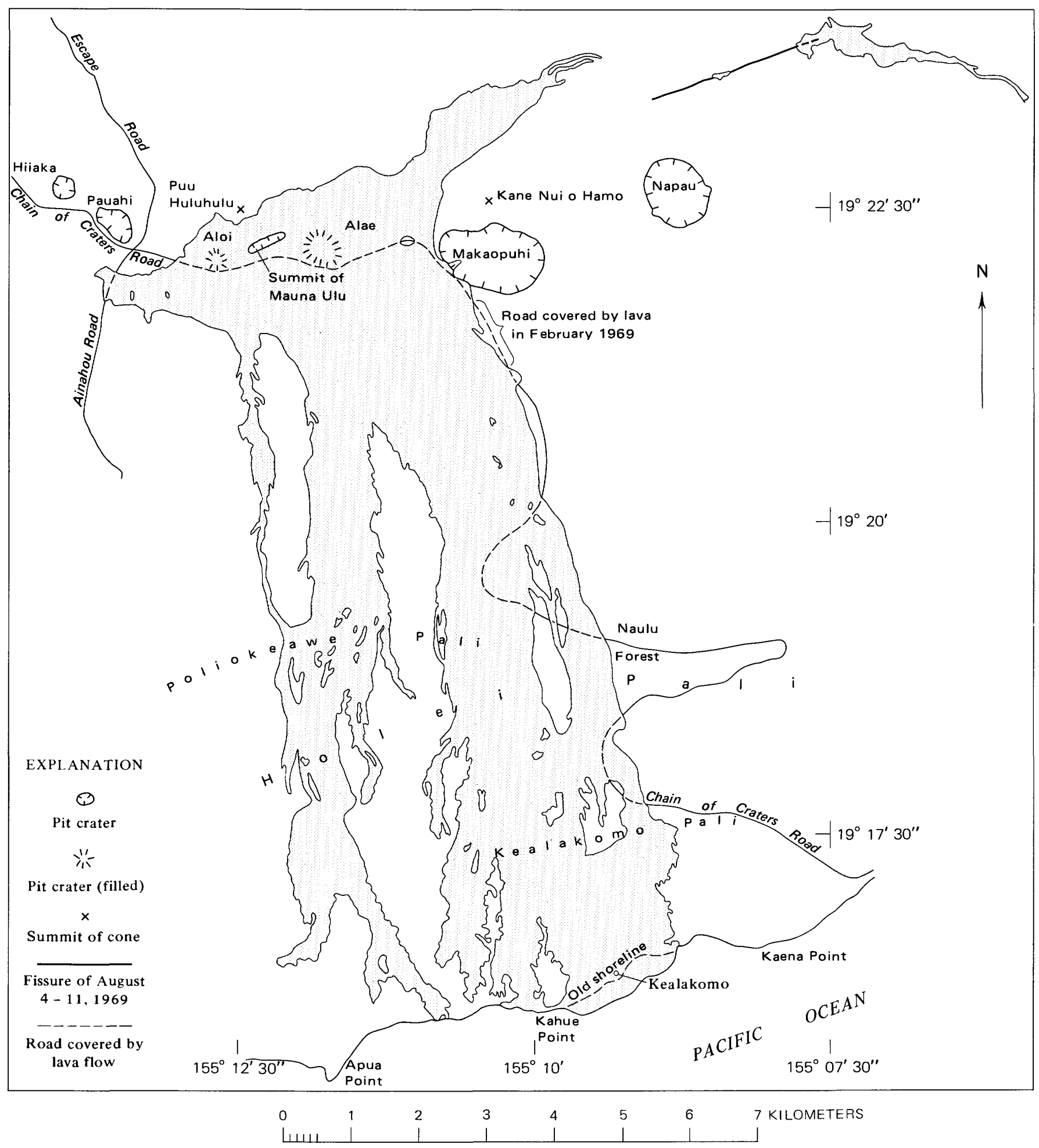

FIGURE 4.-Area covered by basalt flows of the 1969-71 Mauna Ulu eruption. See plate 3 for progressive development of the flows. All flows except those northeast of Napau crater were erupted from a narrow system of fissures trending east-northeast between the Ainahou Road and a point north of Alae Crater. The word "pali" means cliff in Hawaiian. 
companied what we interpret to be the forceful intrusion of magma beneath the southeast part of Kilauea Caldera (Duffield and others, 1976). This intrusion apparently caused structural readjustments in the upper east rift zone, reopening or widening magma conduits to Mauna Ulu and leading to the shield-building of late May and June.

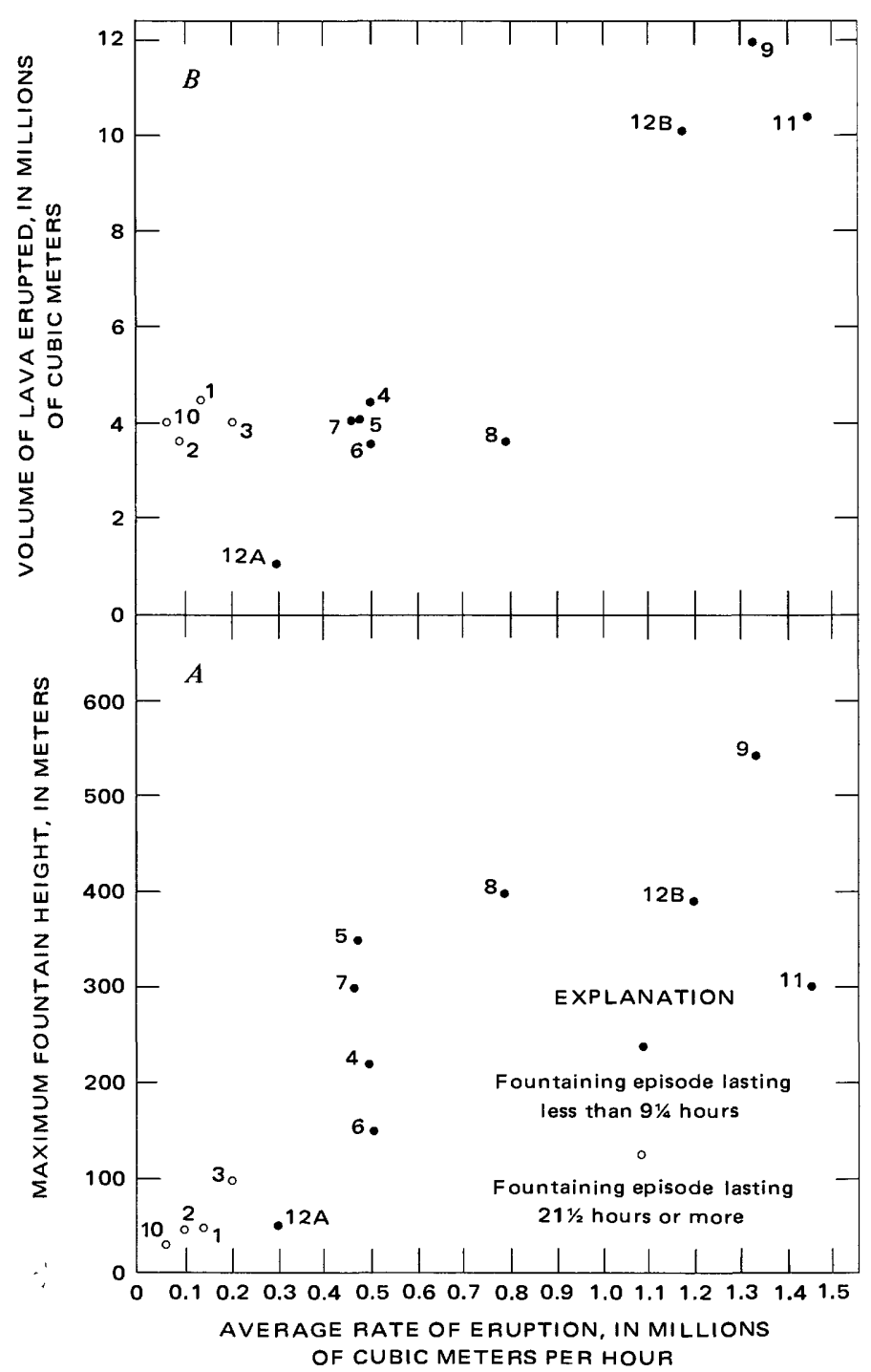

FIGURE 5.-Average rate of eruption compared with maximum fountain height $(A)$ and volume of lava erupted $(B)$ for the 12 episodes of high or sustained fountaining in 1969. Episodes, rates of eruption, volume of lava erupted, and maximum fountain height given in table 5. For most episodes of fountaining, the average rate of eruption is probably not much less than the maximum rate, as fountains typically varied in height by no more than a factor of 1.5-2 except during brief periods at the start and end of an episode. Note that both fountain height and volume of lava tend to vary directly with eruption rate. The four long-lived episodes $(1,2,3$, and 10$)$ produced more lava at low eruption rates than predicted by the other data.
The third stage of the eruption, July 6, 1970 to June 14,1971 , was characterized by repeated activity at several vents along an extension of the fissure system on the east flank of Mauna Ulu. Vent activity was often dominated by gas-piston behavior, with or without overflows. Concurrently, the walls of the summit fissure progressively collapsed, forming a large elongate crater containing a constantly circulating lava lake. Underground conduits from this lake probably fed the vents along the eastern fissure. Lava flowed nearly continuously from these vents through lava tubes (Peterson and Swanson, 1974) into and out of the molten part of the lava lake in Alae Crater, which served as a holding reservoir that modulated the rate of outflow despite some fluctuation in rate of inflow. Lava left Alae through a tube system and eventually spilled out to form a complex tube-fed pahoehoe flow. This flow, a compound flow in Walker's (1972) terminology, advanced $12 \mathrm{~km}$ southward and poured into the ocean on two occasions, September 21-26, 1970 and March 8-May 14, 1971 (Moore and others, 1973; Peterson, 1976). The crust of the Alae lake subsided twice, in early August 1970 and late February 1971, when the clogged outlet tube reopened and some lava drained from the lake to resupply the tube-fed flow (Swanson and Peterson, 1972).

Throughout late 1970 and early 1971 , a subsidence trench gradually developed along the fissure system on the east flank of Mauna Ulu as craters at several of the vents enlarged by collapse and eventually merged. The trench was separated by a narrow septum from the elongate summit crater.

A new fissure opened across the site of Aloi Crater on January 28, 1971 and erupted lava until February 10. The flows built a low mound on the west flank of the Mauna Ulu shield.

The fourth stage of the eruption, June 15 to October 15,1971 , was marked by the slow decline and eventual cessation of eruptive activity. No flows were added to the surface, and the only molten lava visible was in the circulating lake in the summit crater. The surface of the lava lake lowered at a nearly constant rate of $0.7 \mathrm{~m} /$ day (fig. 7), and circulation became increasingly sluggish. The eruption was arbitrarily considered at an end on October 15, when the lava lake could no longer be seen beneath rubble at the bottom of the crater, $145 \mathrm{~m}$ below the rim. The crater and trench continued to widen by collapse as the eruption died. Eventually, the summit crater was more than $185 \mathrm{~m}$ long and $100 \mathrm{~m}$ wide, and the trench was $520 \mathrm{~m}$ long, 40-60 m wide, and $50 \mathrm{~m}$ deep.

The total volume of lava produced during the eruption was calculated in three steps, which involved accounting for the volumes of new lava flows and of the 
Table 5.-Summary of episodes of high or sustained fountaining during the 1969-71 Mauna Ulu eruption

\begin{tabular}{|c|c|c|c|c|c|c|c|}
\hline \multirow{2}{*}{\multicolumn{2}{|c|}{ Episode }} & \multicolumn{2}{|c|}{ Date (1969) } & \multirow{2}{*}{$\begin{array}{c}\text { Duration } \\
\text { (hours) }\end{array}$} & \multirow{2}{*}{$\begin{array}{l}\text { Volume } \\
\text { erupted } \\
\left(10^{6} \mathrm{~m}^{3}\right)\end{array}$} & \multirow{2}{*}{$\begin{array}{c}\text { Average } \\
\text { rate of } \\
\text { eruption } \\
\left(10^{6} \mathrm{~m}^{3} / \mathrm{hr}\right)\end{array}$} & \multirow{2}{*}{$\begin{array}{l}\text { Maximum } \\
\text { fountain } \\
\text { height }(m)\end{array}$} \\
\hline & & Started & Ended & & & & \\
\hline 1 & $-\ldots-\cdots-\cdots$ & 0445 May 24 & 1500 May 25 & $341 / 4$ & 4.5 & 0.13 & 50 \\
\hline 2 & ----- & 1900 May 27 & 0900 May 29 & 38 & 3.5 & 0.09 & 50 \\
\hline 3 & $-\ldots----$ & 1330 June 12 & 1100 June 13 & $211 / 2$ & 4.0 & 0.19 & 100 \\
\hline 4 & $-\ldots \ldots-\ldots$ & 2145 June 25 & 0700 June 26 & $91 / 4$ & 4.5 & 0.49 & 220 \\
\hline 5 & $-----\ldots$ & $0345 \mathrm{July} 15$ & 1220 July 15 & $81 / 2$ & 4.0 & 0.47 & 375 \\
\hline 6 & $--1-1-1$ & 1715 Aug. 3 & 0010 Aug. 4 & 7 & 3.5 & 0.50 & 150 \\
\hline 7 & $-----\ldots$ & 2100 Aug. 5 & 0545 Aug. 6 & $83 / 4$ & 4.0 & 0.46 & 300 \\
\hline 8 & $--\ldots--\ldots$ & 0015 Aug. 22 & 0440 Aug. 22 & $41 / 2$ & 3.5 & 0.78 & 400 \\
\hline 9 & $----\ldots$ & 1930 Sept. 6 & 0430 Sept. 7 & 9 & 12.0 & 1.33 & 540 \\
\hline 10 & $\ldots \ldots-\ldots$ & 0900 Oct. 10 & 1100 Oct. 13 & 74 & 4.0 & 0.05 & 30 \\
\hline 11 & $-----\ldots$ & 0100 Oct. 20 & 0820 Oct. 20 & $71 / 4$ & 10.5 & 1.45 & 300 \\
\hline $12 \mathrm{~A}$ & I $\ldots \ldots$ & 0500 Dec. 30 & 0825 Dec. 30 & $31 / 2$ & 1.0 & 0.29 & 75 \\
\hline 12B & $3 \ldots \ldots$ & 1000 Dec. 30 & 1830 Dec. 30 & $81 / 2$ & 10.0 & 1.18 & 390 \\
\hline
\end{tabular}

Average eruption rate was computed by dividing the volume of lava erupted, estimated from the area and thickness of new flows, by the duration of fountaining.

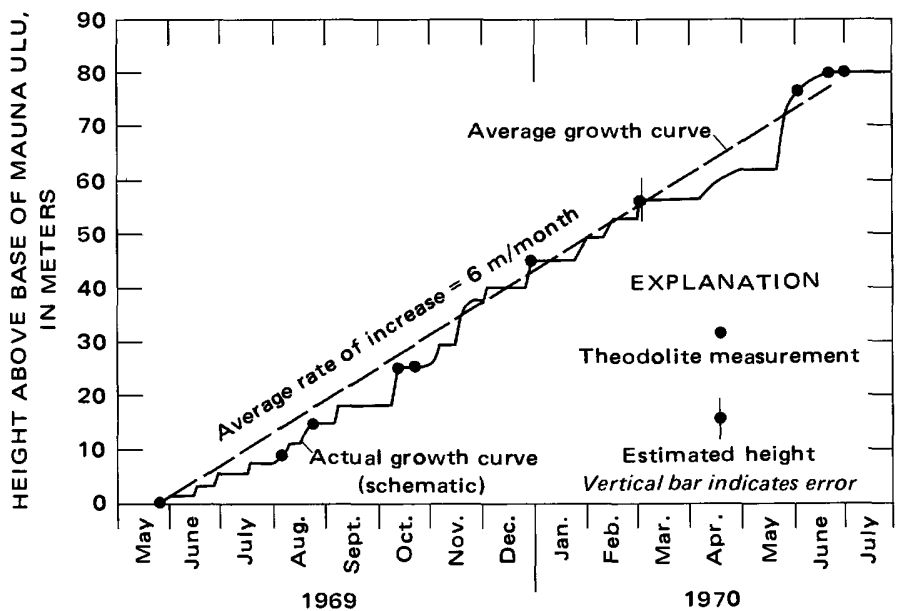

FIGURE 6.-Increase in height of Mauna Ulu shield with time. Ephemeral spatter cones occasionally rose 10-15 m higher than summit of shield (fig. 41). Heights determined by theodolite measurements from the top of Puu Huluhulu. Estimated elevation of preeruption ground surface directly beneath summit of Mauna Ulu, $951 \mathrm{~m}(3,120 \mathrm{ft})$, is calculated from the U.S. Geological Survey's 1:24,000 topographic map of the Makaopuhi Crater quadrangle and adjusted for the thickness of the December 1965 flow.

shield itself, and the filling of Alae Crater (table 6). The volume of lava filling Aloi Crater is too small to be considered in the calculation in light of the probable errors in the measurements, estimated at about 15 per cent. The results show that the field of new flows is about 71 percent, the shield about 19 percent, and the Alae filling about 10 percent of the total volume of 185 x $10^{6} \mathrm{~m}^{3}$ (table 6).

The four stages of the eruption broadly correlate with the degree and rate of tumescence in the Kilauea summit area (fig. 2; pl. 2). During the first stage, expansion took place between fountaining episodes and contraction during each episode. The expansion and contraction nearly cancelled each other, leaving only a small net contraction (fig. $2 B$ ) at the end of the first

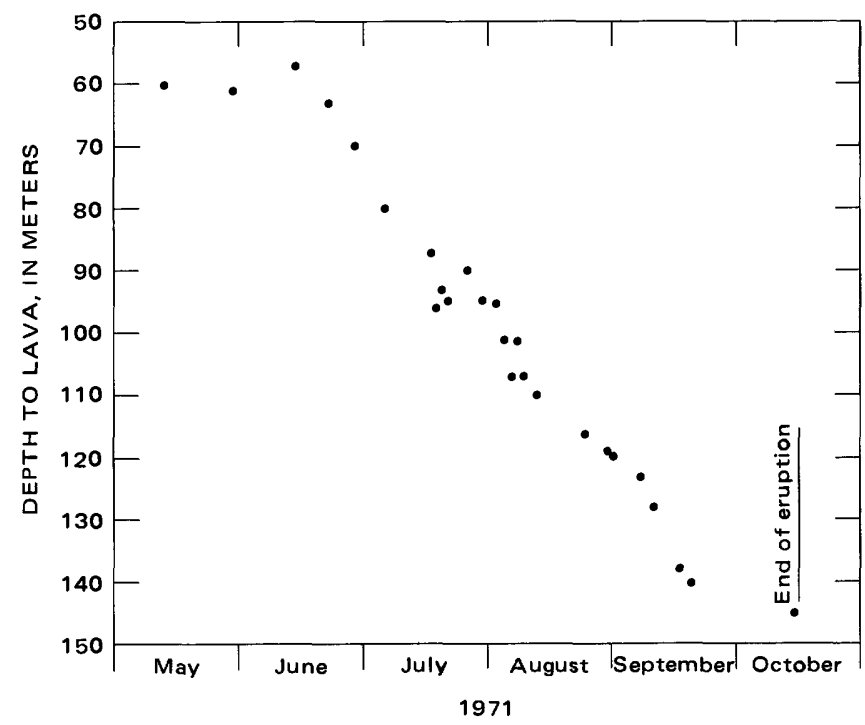

FIGURE 7.-Depth to surface of lava lake below northwest rim of summit crater of Mauna Ulu from May 12 to October 14, 1971. Depth was determined with rangefinder (see fig. 49) and dip angle.

stage. During the second stage, the summit expanded at a rapid rate until late May 1970 and at a reduced rate thereafter, during the period of copious overflows at Mauna Ulu. During the third stage, horizontal expansion (fig. $2 B$ ) continued at a roughly constant rate except for an inflation-deflation cycle centered around the January-February 1971 outbreak. Summit tilt (fig. $2 A ;$ pl. $2 A$ ) increased and then decreased during the third stage. During the fourth stage, the southern part of the summit area began to inflate rapidly (fig. 2A, N-S component), and this inflation continued throughout the summer. Eruptions took place in Kilauea Caldera and along the southwest rift zone in August and September 1971, but neither visibly affected the dying Mauna Ulu activity. 
TABLE 6.-Calculation of volume of 1969-71 Mauna Ulu lava

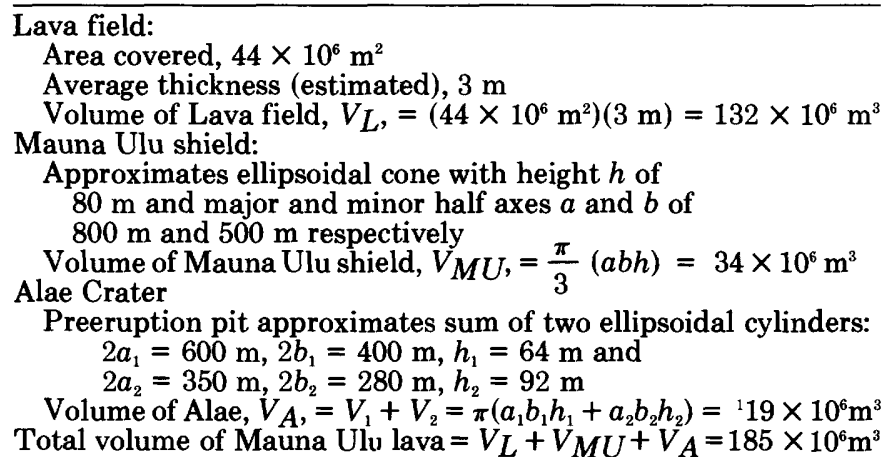

'Excluding more than $3 \times 10^{6} \mathrm{~m}^{3}$ of lava that drained out of the crater on August 4, 1969.

The first three stages of the eruption represent a period of continuous magma supply at a nearly constant rate to Kilauea (Swanson, 1972). The first and third stages each produced flows at average rates of about 9 $\times 10^{6} \mathrm{~m}^{3}$ per month (fig. 8). The rate was less during the second stage, coincident with increased swelling and assumed storage of magma in the Kilauea summit area. The volume of stored magma computed from ground-deformation data, combined with that of the second-stage lava, indicates an average rate of magma addition to Kilauea of about $8.3 \times 10^{6} \mathrm{~m}^{3}$ per month during the second stage, close to the rate for stages 1 and 3 when uncertainties in the deformation models are considered (Swanson, 1972).

Three of the four stages of the eruption are characterized by slightly different chemical compositions of the basaltic lava. Of the five chemical variants defined by Wright, Swanson, and Duffield (1975), variants 1-3 were erupted during only the first stage, variant 4 during only the second stage, and variant 5 during the third stage. No samples could be collected during the fourth, dying stage. A hybrid involving mixtures of variants 3 and 4 was erupted early in the second stage. These variants cannot be related to each other by any recognized fractionation scheme (Wright and others, 1975). Chemical variations during the three main stages apparently reflect processes of magma generation or supply not usually acting during a single $\mathrm{Ki}$ lauea eruption; most Kilauea eruptions generally produce lava that is rather uniform chemically except for the effect of shallow mixing and fractionation. In part, the chemical variations may simply be related to the longer duration of this eruption than most Kilauea eruptions. However, at least some past Kilauea eruptions lasting several months, such as the 1967-68 Halemaumau eruption, produced chemically similar lava throughout the duration of activity (Wright, 1971).

The eruption was the first flank eruption at Kilauea during historic time to include a long-lived active lava lake. Lava in this lake, which can be considered as the upper part of the magma column supplying Mauna Ulu, actively circulated and degassed throughout most of the eruption. Previously, active lakes at $\mathrm{Ki}$ lauea had been observed only in Halemaumau Crater, in the summit caldera. All other so-called lava lakes observed to form at Kilauea have been "inactive" lakes, as they were simply lava flows that ponded within pit craters and were not formed directly on top of a magma column. This kind of lake formation is true even for the well known 1959 Kilauea Iki and 1965 Makaopuhi "lava lakes," which were fed from vents on the crater walls that ceased activity when the level of ponded lava reached and "drowned" them (Richter and Moore, 1966, p. 3; Wright and others, 1968, p. 3196-3197). The easily accessible and longlasting 1969-71 Mauna Ulu eruption afforded good opportunities to study the long-term processes of circulation, growth of crust, drainback, and degassing in the active lava lake (Duffield, 1972).

\section{FIRST STAGE OF ERUPTION}

MAY 24-26, 1969

The first episode of fountaining began at about 0445 May 24 from a zone of fissures that crossed the northern part of Aloi Crater and extended as far east as due north of Alae Crater (pl. 3A). Lava flooded the broad area of active fumaroles just west of Aloi, destroying a bordering swath of forest and leaving a grove of lava trees. The fissure zone quickly opened westward, crossing the Chain of Craters Road by 0500 . Several earthquakes were felt by local residents at about this time. By 0830, a fissure extended across the Ainahou Road (fig. 9) and soon thereafter reached a point $150 \mathrm{~m}$ west of the road.

Color aerial photographs taken by personnel of Sandia Laboratories at 0940 show that spatter cones and ramparts were forming at two main areas of fountaining, one between the western end of the fissure zone and the Chain of Craters Road, the other about halfway between Aloi and Alae Craters, where fountains jetted as high as $50 \mathrm{~m}$ (table 5 ). The photographs also show that Aloi Crater, earlier filled to a depth of $25 \mathrm{~m}$ with a pool of new lava, was now largely empty owing to drainback into a gaping fissure in the floor. Lava was pouring into Alae Crater and had already covered the floor, burying drilling equipment being used in a study of the February 1969 lava lake (Swanson, Jackson, Koyanagi, and Wright, 1976).

Most of the pahoehoe flows from the western area of fountaining advanced southward before ponding at 


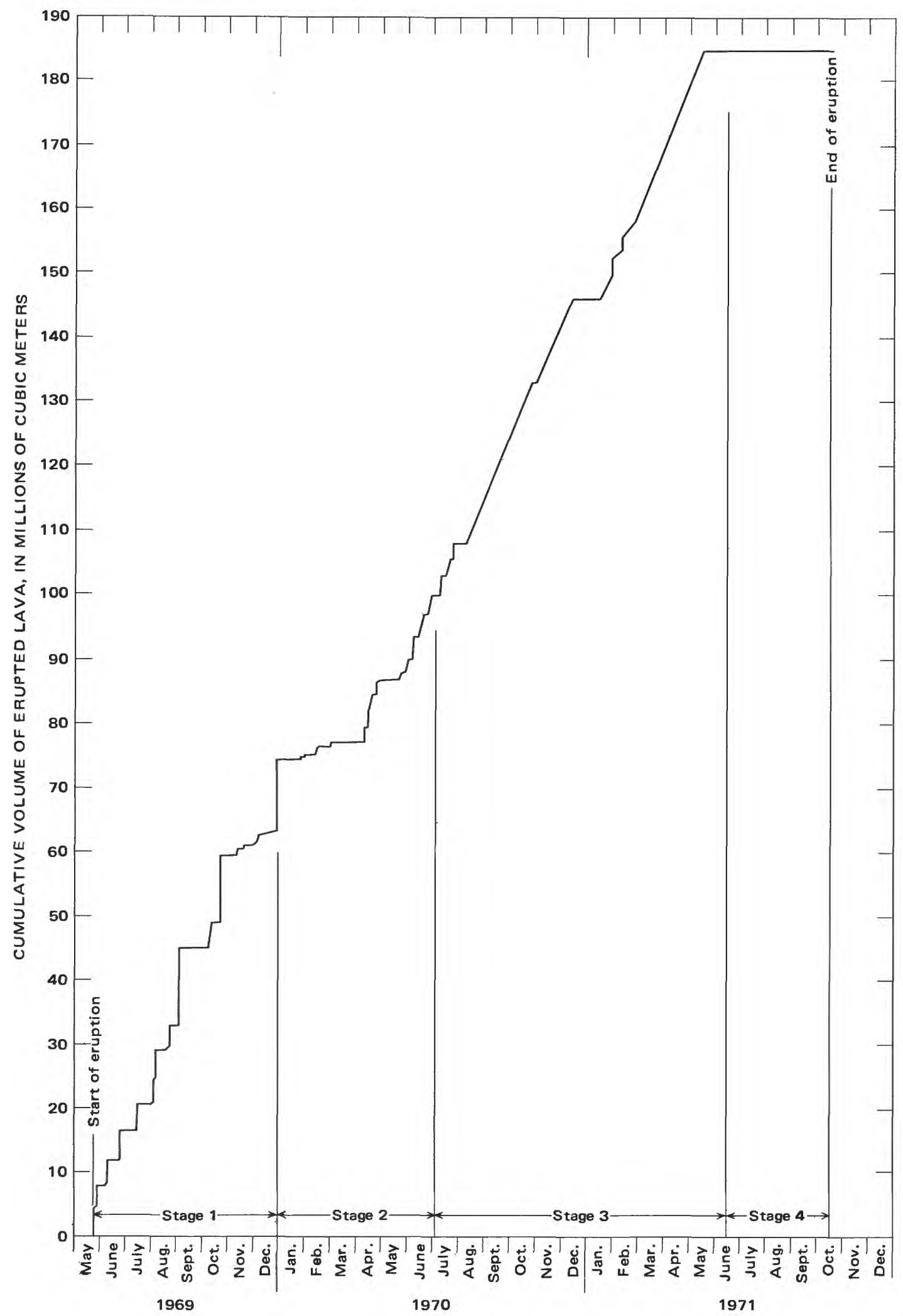

FIGURE 8.-Cumulative volume of lava, including tephra, produced during 1969-71 Mauna Ulu eruption, plotted against time. All volumes during stage 1 and stage 2 and some during stage 3 and stage 4 computed from estimated area and thickness of lava flows and tephra deposits. Most volumes during stage 3 and stage 4 computed from eruption rate determined from observations of lava flowing in lava tubes between Mauna Ulu vent area and Alae Crater. 


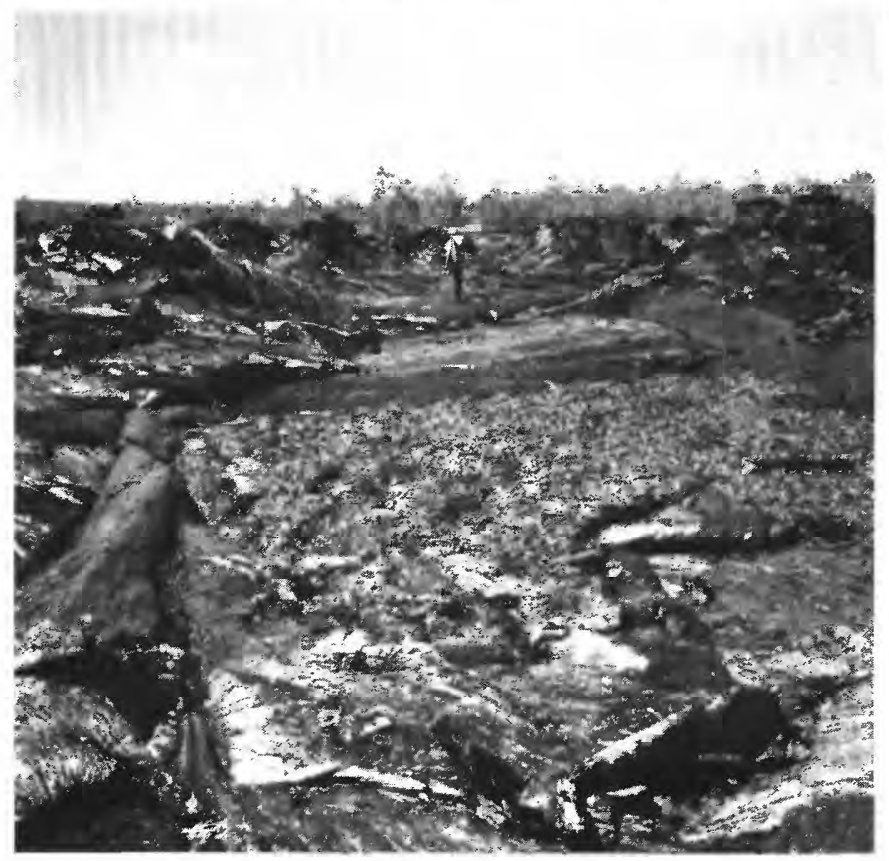

Figure 9.-View northward along trace of Ainahou Road (pl. 3), buried by lava flow erupted from fissure that crossed road near most distant figure on May 24, 1969. Lava trees (right edge) that line trace of road indicate maximum height of flow before spreading laterally and downslope.

the foot of north-facing Kalanaokuaiki Pali (pl. 3A). The flow from the eastern area was briefly impounded behind a row of spatter cones built during the February 1969 eruption just west of Alae Crater (pl. 1; Swanson, Jackson, Koyanagi, and Wright, 1976, fig. 15), but soon the dam was breached, and the flow eventually reached about $1.5 \mathrm{~km}$ from the vent. The February cones were completely buried on May 27, but their location was marked by an abrupt increase in slope of the new lava flows (fig. 15). The steep slope, which persisted for many months despite repeated covering with fresh flows, provided a good geographic reference in an otherwise constantly changing wasteland.

The activity along the western part of the fissure system stopped by 2200 May 24, but weak fountaining continued at the vent area between Aloi and Alae Craters until about 1500 May 25. Harmonic tremor, a type of seismicity that indicates the underground flow of magma, continued thereafter, so that we suspected that the eruption was not over.

The western vents of the fissure system are located within what is generally accepted as the extreme eastern part of the Koae fault system, the first activity in the system in historic time. This part of the fissure system closely follows the gently curved trend of preexisting faults and ground cracks, and the main fissure may coincide with one of these ruptures, although this cannot be documented because of the cover of new lava. The westernmost vent area is located along the trace of a preexisting, north-facing scarp. The chemical composition of lava from this vent (Wright and others, 1975, sample DAS691-10) suggests some mixing with differentiated magma, perhaps stored for some time in this part of the Koae fault system, where eruptions are infrequent but intrusive events common (Swanson, Duffield, and Fiske, 1976, table 1).

The vent area between Aloi and Alae Craters developed into by far the most important vent area of the entire eruption, for it was here that Mauna Ulu, a large parasitic shield, was eventually constructed. This area is designated the Mauna Ulu vent area throughout the rest of the paper.

\section{MAY 27-JUNE 11, 1969}

At 1900 May 27, the second episode of major fountaining began in the Mauna Ulu vent area from two distinct vents, designated the eastern and western vents, about $150 \mathrm{~m}$ apart, along offset segments of the same fissure (pl. $3 A$; fig. 10). An arcuate spatter rampart 8-10 $\mathrm{m}$ high was built up along the west and north edges of the vents, and a low ridge of spatter formed a few tens of meters downwind to the southsouthwest. Lava fountained from both vents, generally higher, as much as $50 \mathrm{~m}$ (table 5), from the eastern vent. These two vents remained separate entities for nine weeks, until the eastern one became inactive.

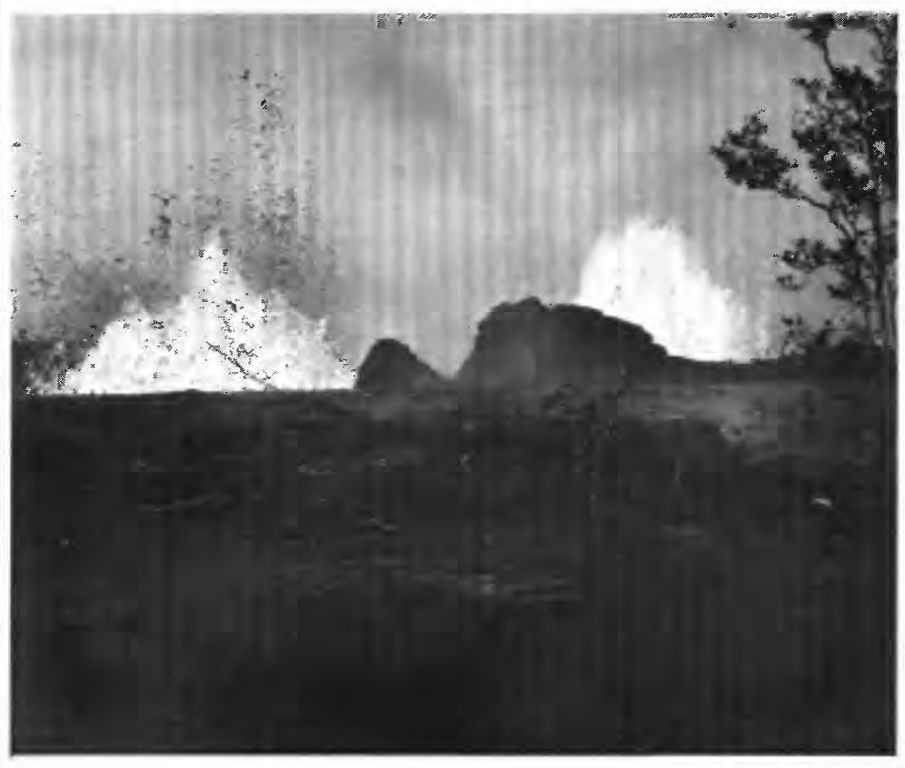

FIGURE 10.-Fountains play from eastern and western vents in the Mauna Ulu vent area, May 28, 1969. View northeast from point $400 \mathrm{~m}$ east of Aloi Crater. Note spatter ridge forming between the vents. 
Pahoehoe spread eastward from the eastern vent into Alae Crater and southward from the western vent across the flows of May 24-25 and February 22 (Swanson, Jackson, Koyanagi, and Wright, 1976). By 1700 May 28, the longest flow reached $1.5 \mathrm{~km}$ south of Alae Crater, and it continued another kilometer before stopping on May 29 (pl. 3A).

Fountaining stopped at 0900 May 29, and no further visible activity took place before June 12 . Harmonic tremor continued, however, and dull rumbling and sloshing sounds were heard during several visits to the vent area. As the lull continued, we became less confident that another episode of fountaining would ensue and hypothesized that the sounds and tremor were related to degassing of stagnant lava left in the fissure system after the late May activity. We were wrong.

\section{JUNE 12-24, 1969}

During reconnaissance for new survey lines at 1315 June 12 , we heard roaring noises coming from the Mauna Ulu vent area a kilometer away. They sounded much like strong winds but persisted for several minutes. One of us investigated, topping a low rise $100 \mathrm{~m}$ away in time to see a column of lava 3-4 m high welling from the western vent and feeding a flow less than $5 \mathrm{~m}$ long. The column was rapidly growing in height and changing from a calm outwelling to a vigorous fountain. The eruption had indeed resumed, with its third episode of fountaining, surprisingly with no premonitory increase in seismicity.

Within two hours, the fountain reached $100 \mathrm{~m}$ (table 5) above the western vent and $75 \mathrm{~m}$ above the eastern vent (Swanson and others, 1971, p. 12, photograph). Fallout of spatter was heavy around the vents, quickly adding to the height of the existing cones, and pumice and smaller bits of spatter blew toward the south-southwest for hundreds of meters, building a low, broad ridge. Strong fountains continued through the night and were still $50-75 \mathrm{~m}$ high at 1045 the next morning. Then, with remarkable swiftness, the fountaining declined and ended. Within 10 minutes, all surface activity was over except for slight overflow from the western vent, and the overflow stopped only 5 minutes later. The fountains surged as they waned, each successive surge lower than the preceding one. Subsequent periods of high fountains in 1969 ended in a similarly rapid, surging manner (for example, fig. 20). Lava pooled above and near the fissure drained back as the fountains stopped.

A small volume of fountain-fed lava cascaded into Alae Crater. Most, however, flowed southward, advancing down and eventually filling and overspilling the channel of the May 27-29 flow. The fluid pahoe- hoe flow reached the end of the May flow in the early evening and continued downslope through a sparse forest. By midnight, the flow had begun cascading brilliantly over Poliokeawe Pali, changing from pahoehoe to aa in the process. By early morning, the flow was pouring over the even steeper Holei Pali and spreading slowly seaward, eventually coming to rest shortly before noon, about $1 \mathrm{~km}$ from Apua Point and nearly $11 \mathrm{~km}$ from the Mauna Ulu vent area (pl. $3 B$ ).

Despite this long flow, the total volume of lava erupted was close to that of the preceding two episodes of strong fountaining (table 5), because most of the lava went into the flow, with only a small amount emptying into Alae Crater or piling up near the vents.

An unusually sharp-peaked, craggy spatter rampart, largely formed by modification of the preexisting rampart, was constructed between the western and eastern vents during the fountaining (fig. 11). This rampart had a shiny, glazed surface created when still molten spatter landed and flowed down the nearly vertical flanks. A broad, discontinuous rampart made of spatter and fragments of crust from natural levees surrounded the entire vent area but was higher on the downwind side. The rounded flanks of the rampart were deeply scored with cracks that formed when the rapidly deposited, still hot tephra began to flow. Some large blocks of the rampart were undermined or bull-

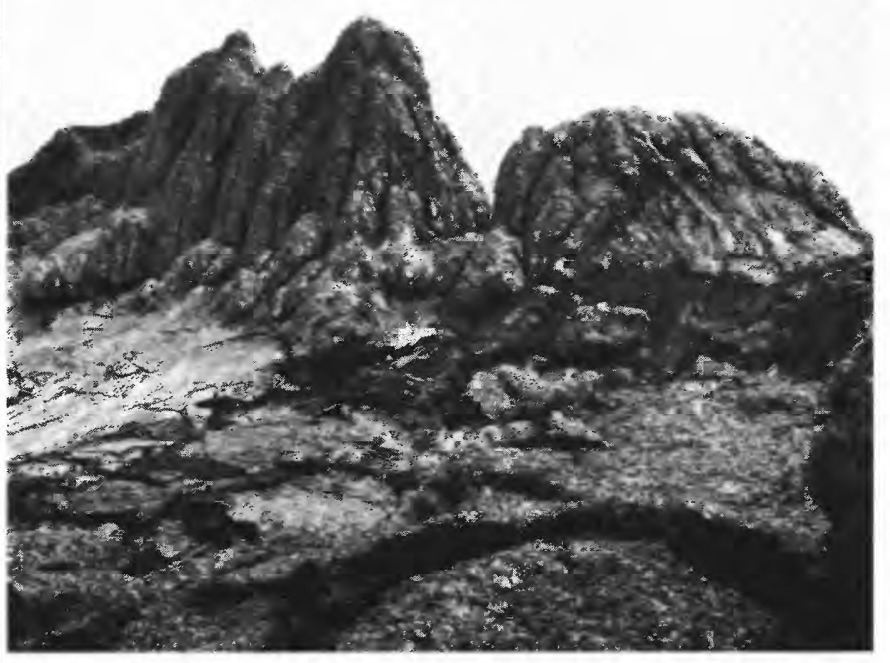

FIGURE 11.-Craggy, furrowed spatter rampart between the western and eastern vents in the Mauna Ulu vent area, viewed from south edge of western vent on June 14, 1969. Peak of rampart about $10 \mathrm{~m}$ above its base. Material in foreground consists of partly welded spatter that slumped toward western vent when lava drained into fissure after fountaining stopped on June 13. 
dozed by the lava flow and carried downslope several hundred meters.

The Mauna Ulu vent area was several meters lower than the area just outside the rampart, owing to drainback into the fissure after fountaining ceased. We call this low area the vent basin (fig. 12). The vent basin remained distinct until the spring of 1970 , often filling with lava that drained away as activity waned. The vent basin was generally several times as wide as the fissure, and its floor usually sloped toward the fissure. As Mauna Ulu grew in height, the rampart and basin floor maintained about the same difference in elevation except for short periods during which the basin partly or entirely filled. Many statements in this narrative are referenced to some height above the floor of the vent basin, which is taken to be the low point of the basin at the rim of the eruptive fissure. As long as both the eastern and western vents were active, each developed its own basin (fig. 12).

For almost 2 weeks, following cessation of fountaining, no lava was visible. Harmonic tremor continued to be detected by nearby seismometers, and lowpitched, thunderous sounds were commonly heard, accompanied at times by a sloshing noise that we later

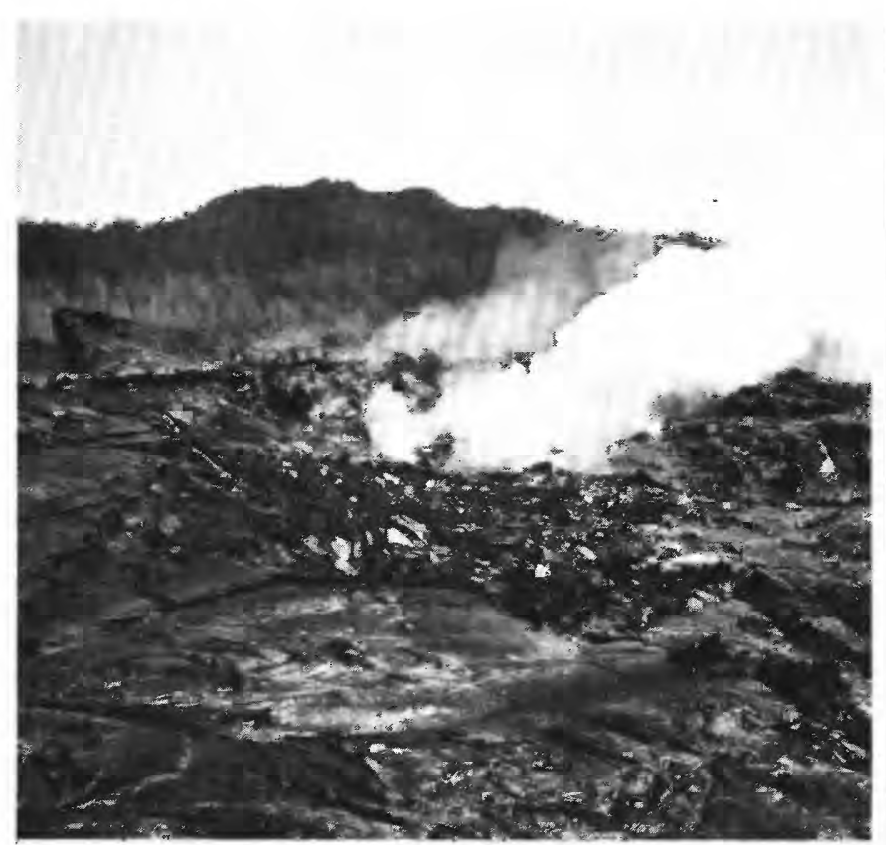

FIGURE 12.--Basin surrounding western vent, June 14, 1969. Fume issues from the last active vent of the previous day. Ledge to left of fume indicates level of lava pooled above vent before drainback. Low spatter rampart is just beyond ledge. Jumbled area in front of fume is slumped material, chiefly viscous lava with some smooth plates of crust, that slid downslope as lava withdrew. Height of ledge above rim of vent, about $7 \mathrm{~m}$. Puu Huluhulu in background. learned to associate with slowly bubbling lava. Small amounts of fume often rose from both vents.

\section{JUNE 25-JULY 6, 1969}

The fourth fountaining episode of the eruption began at 2145 June 25 and ended at 0700 June 26 . In that short $9^{1 / 4}$-hour interval, $4.5 \times 10^{6} \mathrm{~m}^{3}$ of lava erupted, a rate $2 \frac{1}{2}$ times that for the previous fountaining episode (table 5). In other respects, however, the episode was similar to that of June 12-13. Twin fountains rising from the two vents (fig. 13) reached a maximum height of $220 \mathrm{~m}$, giving rise to a thick pumice fallout that added substantially to the tephra ridge downwind (pl. $3 \mathrm{C}$ ) and blanketed the parking lot and road at Aloi Crater to a depth of $50 \mathrm{~cm}$. Flows produced by fallback at the base of the fountains poured across the early June pahoehoe and cascaded over Poliokeawe and Holei Palis (fig. 14). A small volume of aa entered

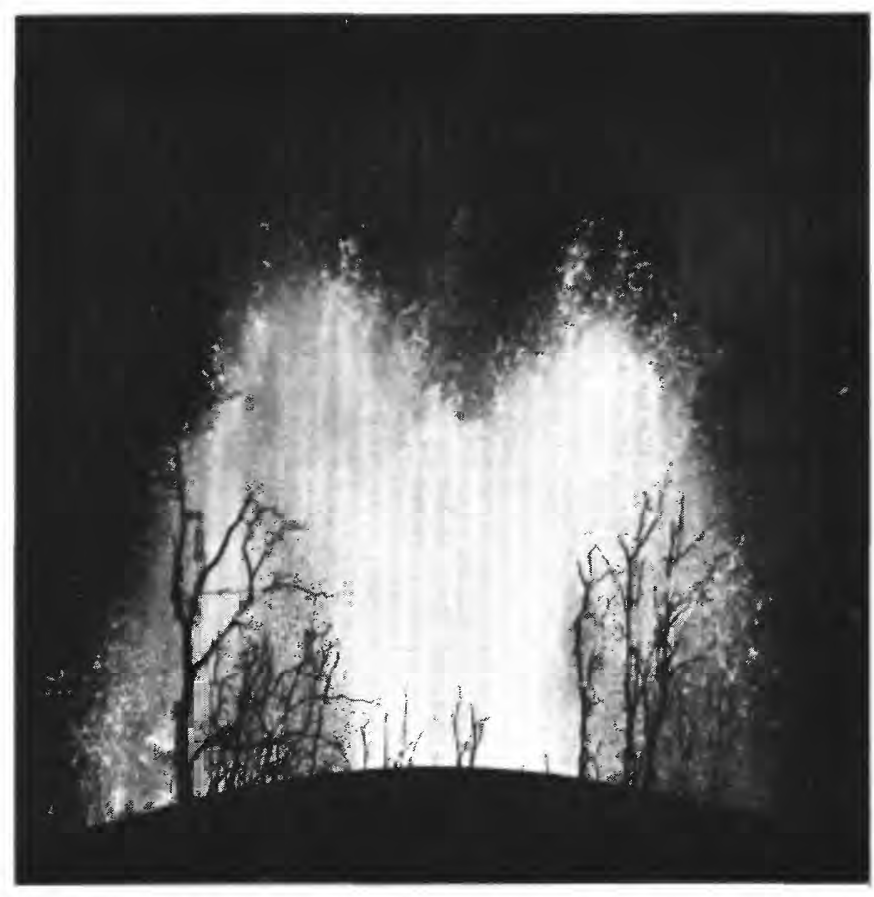

FIGURE 13.-Twin fountains in Mauna Ulu vent area more than $200 \mathrm{~m}$ high erupting during the early morning of June $26,1969$. Defoliated trees are silhouetted above rapidly growing ridge of tephra downwind from vent area. View from southwest.

FiguRE 14.-Holei Pali viewed from several hundred meters seaward of its base, showing lava cascade of June 26, 1969. Note how lava, probably with a fluidity transitional between pahoehoe and aa, surges down the steep slope, much as water moving in a flume. Sticky aa flow (foreground) slowly advances from base of pali. This flow entered the ocean several hours later. Visible height of pali, about $220 \mathrm{~m}$. Photograph by D. W. Reeser, National Park Service. 


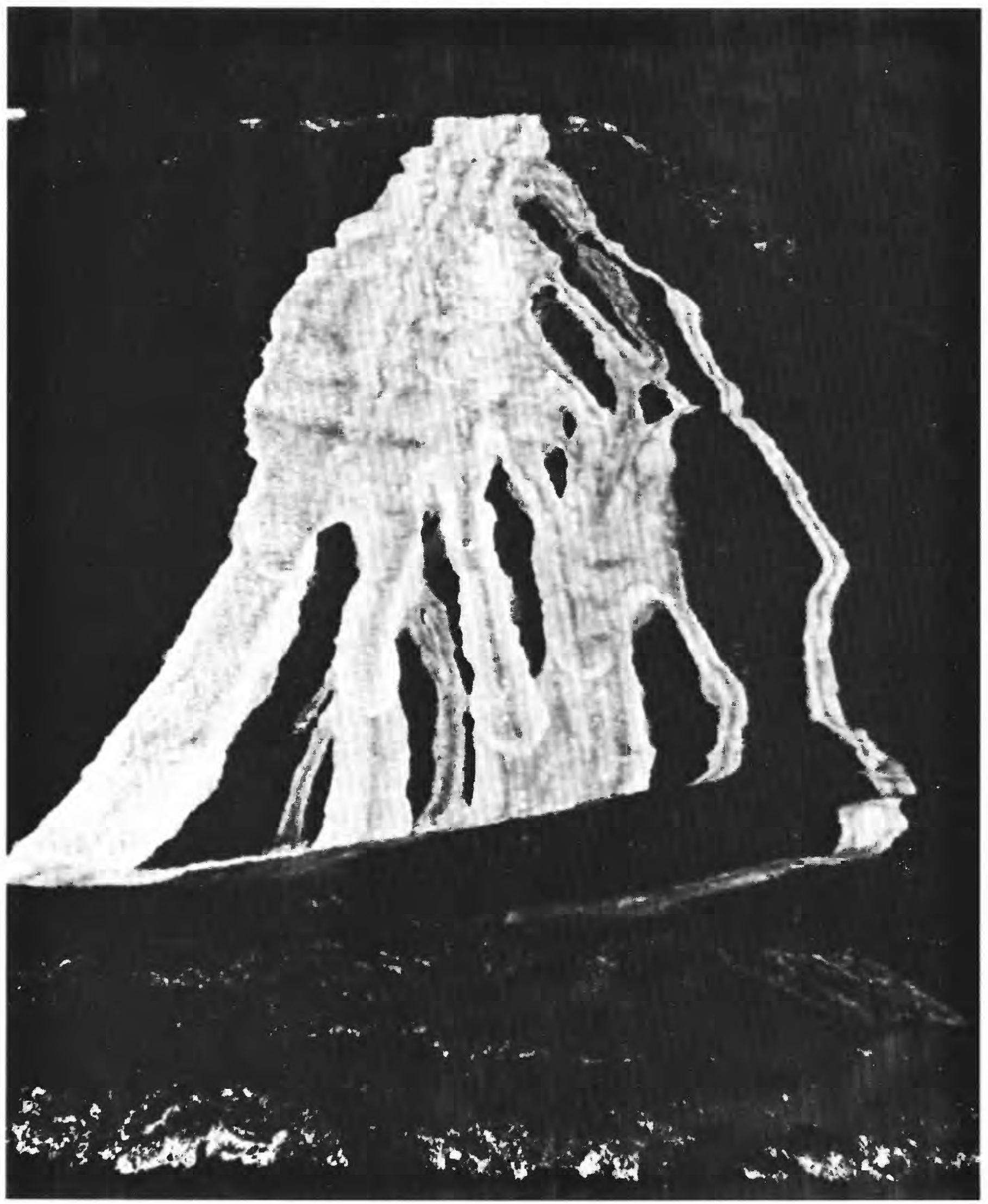


the sea $2 \mathrm{~km}$ east of Apua Point at 0835 June 26, an hour and a half after fountaining ended, forming a jagged point extending $40 \mathrm{~m}$ seaward from the shoreline. Moore, Phillips, Grigg, Peterson, and Swanson (1973, p. 537-539) describe the submarine part of this flow; the flow is estimated to have a volume of about $0.1 \times$ $10^{6} \mathrm{~m}^{3}$ (Peterson, 1976). About $1 \times 10^{6} \mathrm{~m}^{3}$ of lava was added to Alae Crater, raising the floor of the crater by $7 \mathrm{~m}$ to $30-35 \mathrm{~m}$ below the low point on the rim. Most of the Chain of Craters Road near Alae Crater was now covered with new flows (fig. 15).

The basic configuration of the Mauna Ulu vent area remained unchanged during this outburst. The spatter ramparts grew slightly higher and became less craggy. The fissure widened to nearly $5 \mathrm{~m}$ at the eastern vent, and one could peer into it and into a hole beneath the rampart separating the two vents (Swanson and others, 1971, cover photograph). The broad ridge of spatter and pumice downwind from the vent area increased several meters in height and encroached still more on the forest, now almost completely denuded by falling tephra within $1 \mathrm{~km}$ of the vent area.

$$
\text { JULY 7-14, } 1969
$$

Ten days of subterranean sounds, harmonic tremor, and periodic outrush of hot gas from the vents followed the June 25-26 activity, but no lava was observed until July 7, when it reappeared in the eastern vent of the Mauna Ulu vent area. The lava remained unagitated in the fissure except for brief periods when it emitted short-lived bursts of spatter or rose to the lip of the vent and spilled out into the vent basin as flows of only a few square meters extent. We could easily approach and sample the lava column at such times. This was the first episode of what was to become one of the dominant modes of eruption at Mauna Ulu; in fact, after December 30, 1969, all activity was basically this type, although with many embellishments and degrees of vigor. It was at this time that we first observed a cyclic rise and fall of the lava column, a process that we saw many times subsequently and ascribed to a gas-piston mechanism. One of the best examples of this process occurred on July 29-30; it is described in the section dealing with that period. The frequency of spattering, fissure overflows, and cyclic rise and fall of the lava column gradually increased from July $7-14$, as if leading up to another period of high fountaining.

\section{JULY 15-19, 1969}

The fifth episode of strong fountaining began at 0345 July 15 , and by 0430 lava was spraying nearly 375 $\mathrm{m}$ into the air. The highest fountains issued from the eastern vent in the Mauna Ulu vent area, although

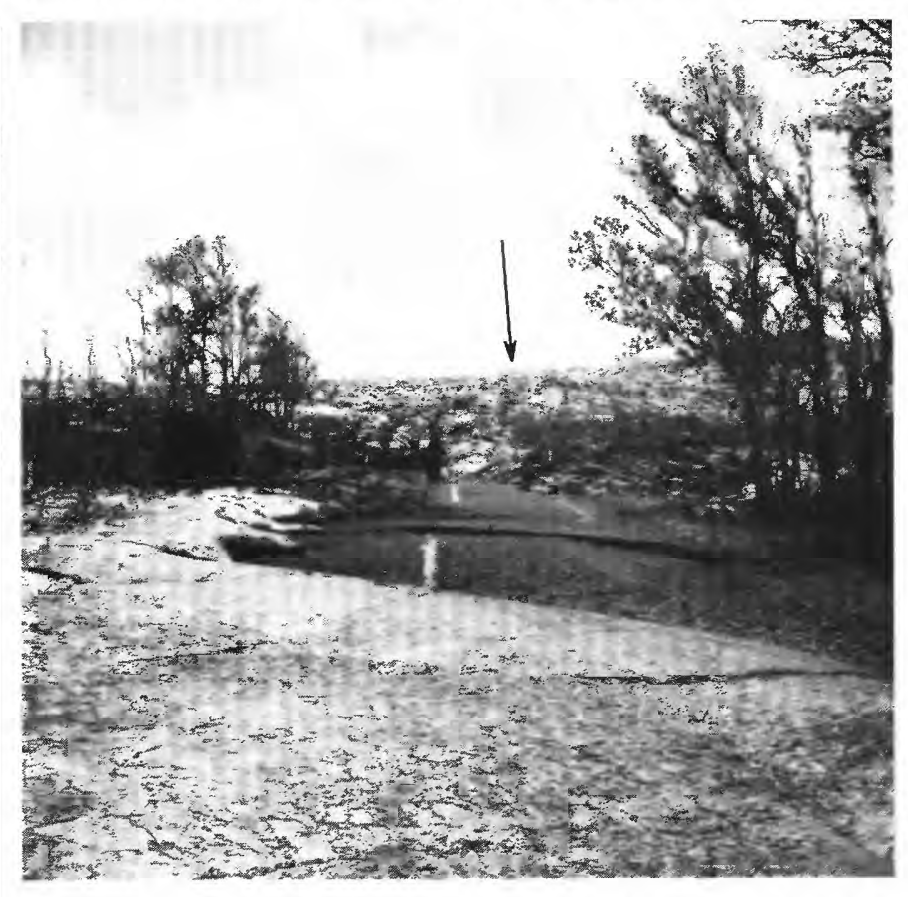

FiguRE 15.-Flows erupted on June 25-26, 1969 cover Chain of Craters Road near southwest rim of Alae Crater. Large crack offsetting center line of road formed during February 1969 eruption (Swanson, Jackson, Koyanagi, and Wright, 1976). Arrow indicates abrupt increase in slope of new flows across buried row of February 1969 spatter cones. Mauna Ulu vent area hidden behind trees on right. Photograph taken June 29, 1976.

fountains from the western vent reached heights of over $200 \mathrm{~m}$. Two parallel ridges of coarse pumice and spatter forming part of a broad complex tephra mound were built by the double fountain, one east and the other west of the channel of the main lava flow moving southward (pl. $3 D$ ). This flow eventually reached the coastal flat below Holei Pali at about 1800 July 15 but stopped short of the ocean. The flow bulldozed large blocks of welded spatter, some the size of a house, from the cone and carried them hundreds of meters downslope. A second flow coursed though a well-developed channel northeast from the east fountain, spilling $2 \times 10^{6} \mathrm{~m}^{3}$ of lava into Alae Crater. Most of this new lava plunged through the thin crust on the June 25-26 fill and hydraulically lifted the crust about $15 \mathrm{~m}$, to within $15-20 \mathrm{~m}$ of the rim of the crater (Swanson and others, 1972). A third, smaller flow advanced northwest from the east fountain, turned west and then south around the growing pumice and spatter mound, and spread over the parking area just east of Aloi Crater before joining the main stream moving southward.

During fountaining, a pool of lava fed directly by molten fallout accumulated in the vent basin, impounded by spatter ramparts. This pool, which continuously overflowed the ramparts, was the main 
source of the flows. When fountaining stopped at 1220 July 15 , lava in the pool quickly drained into the two eruptive fissures, leaving a glaze on the ramparts that was much richer in olivine than the associated flows. The abundant olivine phenocrysts may be "lag gravel" left after liquid drained away, or, more likely, they may indicate that the last lava erupted was enriched in olivine while still underground. The eastern vent produced much more than half the total volume erupted, $4 \times 10^{6} \mathrm{~m}^{3}$ (table 5), but this was the last time that it was visibly active until August 2-3, 1970.

Ten hours after fountaining ended, welded spatter and large masses of glowing semisolid material were still oozing and rolling from the steep ramparts back down the east vent, which was about $5 \mathrm{~m}$ in diameter. Hot sand-sized debris abraded from falling blocks was blasted into the faces of observers by gases rushing from the vent.

Harmonic tremor slackened markedly when the July 15 fountaining stopped, then increased only two hours later, seemingly a premonition of future eruptive activity, but no lava was seen until July 20 .

\section{JULY 20-AUGUST 2, 1969}

The lava column reappeared in the western vent on July 20 and periodically rose and fell for the next several days. Generally the pumping action changed the level of lava by only a few meters, but occasionally the top of the column would drop 45-50 m, to a point about $50 \mathrm{~m}$ below the lip of the fissure, within 5-10 minutes. Then the column would begin slowly rising, regaining its old level in an hour or less. Relatively small quantities of spatter were ejected during this activity, almost always as the column receded. Lava remained within the fissure, which varied in width between 3 and $7 \mathrm{~m}$ daily depending on the amount of accretion or collapse of the walls, until the night of July 28 , when a thin overflow partly covered the floor of the vent depression.

On July 29-30, a notable sequence of events provided fine examples of the gas-piston mechanism for observers, who could look down into the fissure from their perch on a spatter rampart a few meters away. The lava column, capped by a shimmering layer of flexible but solidified crust several centimeters thick, would slowly rise from a depth of $30-50 \mathrm{~m}$ to the ground surface in 10-15 minutes, accompanied by little or no spattering. Lava would then spill outward from the fissure, pooling against the gentle slope (about 1 in 20) of the vent basin. The top of the lava column was convex upward, and the edge of the lava pool was about $1 \mathrm{~m}$ lower than the central part directly above the feeding column. Sometimes the pool reached a diameter of $150 \mathrm{~m}$, but generally it was half that size. Suddenly, spattering would start from the east end of the drowned fissure, and the pooled lava would begin to drain rapidly back into the fissure, accompanied by extremely vigorous spattering and gas discharge. This drainback was most dramatic; the lava column would drop 25-30 m within 30 seconds and would reach $50 \mathrm{~m}$ depth in another minute. Then the cycle would repeat itself, after a brief recovery time of 1-3 minutes. A complete 10-20 minute cycle, including a surface pool and deep drainback, was typical, but sometimes the column never reached the surface before drainback, and at other times the level sank only a few meters during drainback before a new uprising began.

Several times on these two days, we were able to trigger drainbacks by throwing rocks through the thin crust on the pool. Vigorous spattering began immediately after the crust was broken and gases could escape. During subsequent months, we repeatedly triggered drainbacks using various materials to break through the crust. Generally, the experiments caused drainback only when the system was already prepared to drain back naturally. Slightly premature drainback could sometimes be induced by throwing containers filled with water or gasoline through the crust. These bombs burst forcefully after immersion for several seconds, tearing large holes in the crust and stirring the lava, leading to vigorous degassing, loss of volume of the columns, and drainback.

The total volume of lava and gas that evacuated the fissure during a typical drainback, whether natural, artificially triggered, or induced prematurely, varied from $10^{4}$ to $3 \times 10^{4} \mathrm{~m}^{3}$, calculated from the observed dimensions of the fissure and the surface pool. Such a volume typified all subsequent gas-piston activity for which calculations were made, despite very different vent configurations in 1970 and 1971.

The fissure became largely roofed over by July 31 , the result of accretion of crust and spatter to the upper part of its walls, leaving a lens-shaped opening $3 \mathrm{~m}$ by $7 \mathrm{~m}$. The seal was completed the next day except for two holes, around which low spatter cones were built. Eerie blue and green flames of burning hydrogen played from the cones, a common occurrence around vents from which hot gas escapes (Naughton, 1973; Cruikshank and others, 1973). Conditions remained unchanged until the afternoon of August 3.

\section{AUGUST 3-4, 1969}

The sixth episode of strong fountaining began at 1715 August 3; it was one of the most noteworthy sequences of events of the entire eruption. This episode differed from the previous two in that the fountains were lower $(150 \mathrm{~m})$ (table 5$)$, the eastern vent was inac- 
tive, and several vents periodically erupted west of the main vent complex. These subsidiary vents were not alined along the trend of the main fissure and define no trend of their own. We suspect that they were openings in small lava tubes developed in the July 15 flows and that lava was fed into the tubes from the main vent itself.

The basin around the inactive eastern vent filled when lava that had ponded in the western vent spilled over the intervening spatter rampart. Lava then flowed through a low point in the eastern rampart and cascaded into Alae Crater, raising lake level to within $10 \mathrm{~m}$ of the low part of the rim. As on July 15, the surface crust on the Alae lake floated upward as lava from the cascades plunged beneath it; now the crust was more than $20 \mathrm{~m}$ higher than when it originally formed on June 25-26. About half of the newly erupted lava entered Alae; the rest was distributed as thin flows that extended short distances away from the vent area. The basic configuration of the vent area was little modified, but the large mound of welded spatter and pumice downwind of the fountains grew several meters higher.

The fountaining episode ended at about $0010 \mathrm{Au}$ gust 4 , and those observers still on the scene quickly went home to bed. However, they got little rest, as Swanson, Duffield, Jackson and Peterson (1972, p. 114-116) described:

A vigorous epsiode of harmonic tremor and earthquakes took place between 0400 and 0430 , August 4 -just 4 hours after the Mauna Ulu vents quieted and lava stopped flowing into Alae. The sky was lit in a brilliant glow over Alae during that dramatic half hour, prompting observers to suspect resumption of eruptive activity. Actually, however, Alae lava lake was catastrophically draining into one or more cracks that had suddenly opened and intersected the still molten February 1969 lava in the bottom of Alae's deepest pit. In this half hour, the level of the lake dropped $80 \mathrm{~m}$ as about 10 million $\mathrm{m}^{3}$ of lava drained out. The mezzanine [the flat floor of an older crater exposed at the west end of Alae] was uncovered, even though coated by several meters of viscous lava and solidified crust. This episode was accompanied by violent ground cracking between Alae Crater and Kane Nui o Hamo, a cone north of Makaopuhi Crater. A complex deep crack and fault-bounded graben $10 \mathrm{~m}$ wide and locally more than $70 \mathrm{~m}$ deep extended $800 \mathrm{~m}$ eastward from near the rim of Alae Crater, and a shallow topographic trough continued eastward for another $700 \mathrm{~m}$. The graben and related cracks are probably the surface expressions of the fissure that drained the crater. Prehistoric lava veneer clinging to the walls of the graben shows it to be an old structure reactivated during the draining event.

The lava that drained from Alae apparently intruded eastward beneath the graben and trough, for rocks along the fractured zone were too hot to touch as late as 1000 that morning. About 1400 that same day a lava flow began issuing quietly from a new fissure $3 \mathrm{~km}$ east-north-east of Napau crater [pl. 1; pl. 3E]. This lava is the same chemically and petrographically as that drained from Alae. ${ }^{* * *}$ The volume of lava $* * *$ [added] ${ }^{* * *}$ to the surface is only 25 percent of the volume of lava drained, so about 7.5 million $\mathrm{m}^{3}$ of lava was added in storage to the rift conduit system.

No draining took place from Alae during daylight hours of August 4, but cool viscous lava continued to ooze from pockets left on the crater walls. Masses of partly molten, partly solidified lava as large as houses slowly slid across the gently sloping mezzanine floor like hot earthflows, draped over the newly exposed rim, and ploughed into the sticky degassed lava left in the deeper pit. Occasionally large plates or solidifed lava veneer clinging to the vertical wall of the crater broke loose and crashed to the floor. A black 'bathtub ring' marking the highest stand of the lake encircled the crater walls.

The eruptive activity east-northeast of Napau Crater continued until August 10 or 11 . We originally thought (Swanson and others, 1972, p. 115) that this lava might have been stored in the east rift zone since the August 1968 eruption (Jackson and others, 1975), but further chemical study shows instead that this lava is more similar to that erupted at the Mauna Ulu vent area during the summer of 1969 (Wright and other, 1975, table 6, sample DAS69-67-4). Hence the new flow may well have contained some of the same lava that drained out of Alae Crater.

We do not know the reason for the draining of Alae and the severe ground cracking and dilation of the rift zone (one 250-m-long geodimeter line across the graben lengthened $2.7 \mathrm{~m}$ ). One interpretation is that the weight of new lava added to Alae Crater since February 21,1969 (between $10^{10}$ and $10^{11} \mathrm{~kg}$ ) caused the floor of the crater to collapse into a magma reservoir, whose initial draining hundreds of years previously had caused Alae Crater to form. The south flank of Kilauea underwent no detectable seaward displacement during this event (Swanson, Duffield, and Fiske, 1976, fig. 10), as commonly accompanies the forceful injection of magma into the rift zone.

\section{AUGUST 5-6, 1969}

No eruptive activity was noted at the Mauna Ulu vent area on August 4, but spattering was observed at 1000 August 5. Such activity continued throughout the afternoon, building a horseshoe-shaped spatter cone $8 \mathrm{~m}$ high around the west end of the western vent. Occasionally lava spilled out of the fissure and fed small flows in the vent basin, much as before the August 3-4 activity (fig. 16).

Fountaining to heights of $15-20 \mathrm{~m}$ began slowly at about 1900 that evening. The activity waned at 2000 , allowing close approach to the vent, then picked up quickly at 2100 , with lava spurting to $30 \mathrm{~m}$. The height of the fountain continued to increase, eventually attaining $300 \mathrm{~m}$, so that we arbitrarily set the start of the seventh episode of high fountaining at 2100 August 5 . The western vent was again the principal source of lava, although two subsidiary vents a few tens of meters west contributed a small volume; these subsidiary 


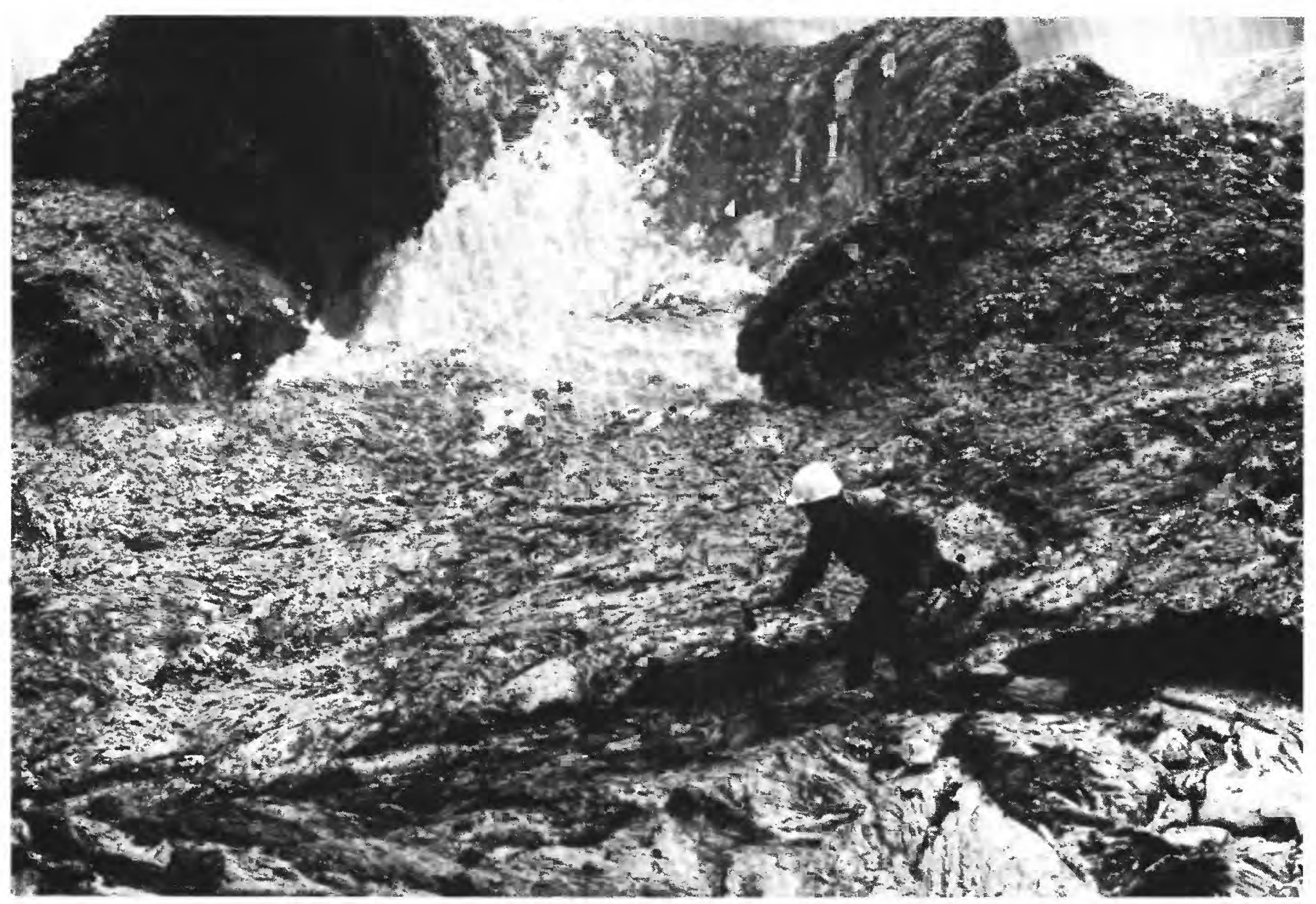

FIGURE 16.-Spattering from horseshoe-shaped cone at west end of western vent, 1500 August 5, 1969. Man is using rock hammer to collect sticky, molten lava from flow slowly advancing from cone.

vents were probably two of those active on August 3 . The basin around the western vent was filled by 2115 , submerging the spatter cone formed earlier in the day, and lava spilled over the intervening ramparts into the basin around the inactive eastern vent, in which lava pooled $20 \mathrm{~m}$ deep. Nearly all the erupted lava, fed either directly by the fountains or via the eastern pool, flowed to the northwest rim of Alae Crater and cascaded more than $100 \mathrm{~m}$ into the pit, which had nearly emptied only two days before. This great glowing cascade, more than $300 \mathrm{~m}$ wide, was one of the most magnificent sights of the eruption (Swanson and others, 1972 , p. $116-117$ and fig. 8 ). About $3.5 \times 10^{6} \mathrm{~m}^{3}$ of lava, almost ninety percent of the total volume erupted during the episode (table 5), had entered Alae by the time the fountaining episode ended at 0545 August 6 . A small aa flow, apparently fed as the lava pond in the west vent area periodically sloshed over its banks, advanced $100 \mathrm{~m}$ northward form the vent. The lava ponded above the eastern vent did not drain away, indicating that the vent had become plugged.
AUGUST 7-21, 1969

Lava returned to the western vent early on August 7 and remained visible for the next two weeks. For the first week, activity was cyclic, with alternating slow rises and rapid falls of the lava column similar to that of July 29-30, except that there were fewer overflows. The fissure gradually roofed itself with spatter and congealed crust, leaving only a changeable number of small openings through which the pulsating column could be seen. When the column degassed during withdrawal, spatter would thud against the base of the roof, producing hollow sounds and thickening the roof enough to support the weight of the adventurous observers.

Activity picked up at 1130 August 15, and spatter from fountains $15 \mathrm{~m}$ high rapidly built a cone at the west end of the fissure. The spatter produced a flow that moved $15 \mathrm{~m}$ eastward before plunging into a hole in the roof of the same fissure (fig. 17). The volume rate of eruption was about $180 \mathrm{~m}^{3} / \mathrm{min}$, but almost all the erupted lava returned underground. Sometimes 


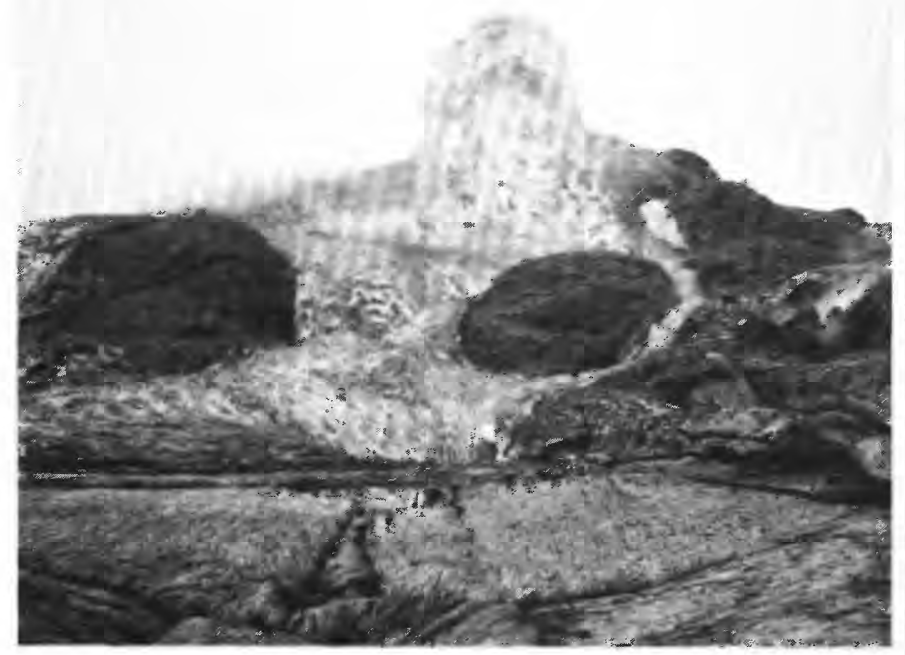

FIGURE 17.-Fifteen-m-high fountain at west end of fissure feeding flow that moves $15 \mathrm{~m}$ toward observer before plunging into a hole in the roof of the fissure, August 15, 1969. Lava also issues from small hole in right flank of newly built spatter cone.

large pieces of the new cone spalled off and floated toward the drainback hole, temporarily plugging it and causing lava to pond within the basin. Short-lived holes commonly pierced the walls of the spatter cone and, before sealing, fed small flows that buried the adjacent part of the rampart surrounding the vent basin.

Over the next several days, fountain height decreased and the cone, after growing $15 \mathrm{~m}$ high, largely roofed itself, although spattering continued to occur within it. Lava was fed to the surface through a vent in the cone, and the drainback hole progressively enlarged by collapse. From time to time, holes opened for a few hours in the thin roof of the fissure and lava poured from them.

The tempo of activity slowly increased during the afternoon of August 21. By 2100 a flow was advancing from the vent area toward Puu Huluhulu, and harmonic tremor intensified.

\section{AUGUST 22, 1969}

The eighth episode of strong fountaining began at about 0015 August 22 . The fountain was $300 \mathrm{~m}$ high within an hour and reached its peak height, about $400 \mathrm{~m}$, in another hour. The western vent was again the principal source of lava, but low, weak fountains issued from several new vents along the trace of the May 24 fissure system (pl. 3E). One set of vents extended about $300 \mathrm{~m}$ downrift (eastward) from the main vent complex, the other set, $200 \mathrm{~m}$ uprift. Low spatter cones formed at several of these new vents. A flow moved southward but stopped only $2 \mathrm{~km}$ from the vent area. Most of the erupted lava again entered Alae, adding about $2.7 \times 10^{6} \mathrm{~m}^{3}$ to the crater and raising the crusted surface of the lake to within $34 \mathrm{~m}$ of the low point on the rim (fig. 18). A thin sheet flood of pahoehoe advanced to the base of Puu Huluhulu, covering much of the aa flow erupted on August 5-6. The inactive eastern vent opened at some stage, though it did not emit fountains, and much of the still-liquid lava ponded above it since August 6 drained away (fig. 19). Winds were strong and fallout heavy during fountaining, resulting in substantial growth of the welded spatter and pumice mound, now nearly $30 \mathrm{~m}$ high, and more devastation of the neighboring forest (fig. 20,21). As during previous fountaining episodes, large masses of welded, still hot spatter from the interior of the cone were remobilized beneath the heavy blanket of newly fallen spatter and sloughed downslope as aa-like flows with very rough surfaces. Spatter falling on the cone which formed on August 15 built it more than $25 \mathrm{~m}$ high. The episode was the shortest of the series, about $4 \frac{1}{2}$ hours, but it produced lava at the highest rate up to that time (table 5).

\section{AUGUST 23-SEPTEMBER 5, 1969}

We waited a day to let the newly erupted flows cool; then we returned to the vent area on August 23 and found an important change in the western vent. The roof over the fissure had been largely destroyed during fountaining, leaving two openings, designated as the eastern and western compartments of the western vent; each compartment was in the bottom of a broad, shallow basin (fig. 22). The eastern compartment, measuring $5 \mathrm{~m}$ by $12 \mathrm{~m}$, was centered over the main drainback hole of August 15-21 and was separated by a 4-m-wide bridge from the western compartment, which was $5 \mathrm{~m}$ by $8 \mathrm{~m}$. Both compartments narrowed downward, and at the deepest visible level in the eastern compartment, about $50 \mathrm{~m}$ wide, the orifice was only 1-2 $\mathrm{m}$ wide. No lava was visible, but bubbling noises came from deep within the eastern compartment. The rampart along the north edge of the western vent area was barely recognizable, as the vent basin was largely filled. Relicts of a rampart were still prominent along the north and, especially, south sides of the inactive eastern vent.

Lava was next seen on August 28 at a depth of $30 \mathrm{~m}$ in the eastern compartment, but it had overflowed twice the previous night, leaving thin flows. From then through September 5, the lava column remained visible deep in the eastern compartment, bubbling and emitting large volumes of fume. The western compartment remained inactive until September 4, when degassing noises were heard, and the wall of the 


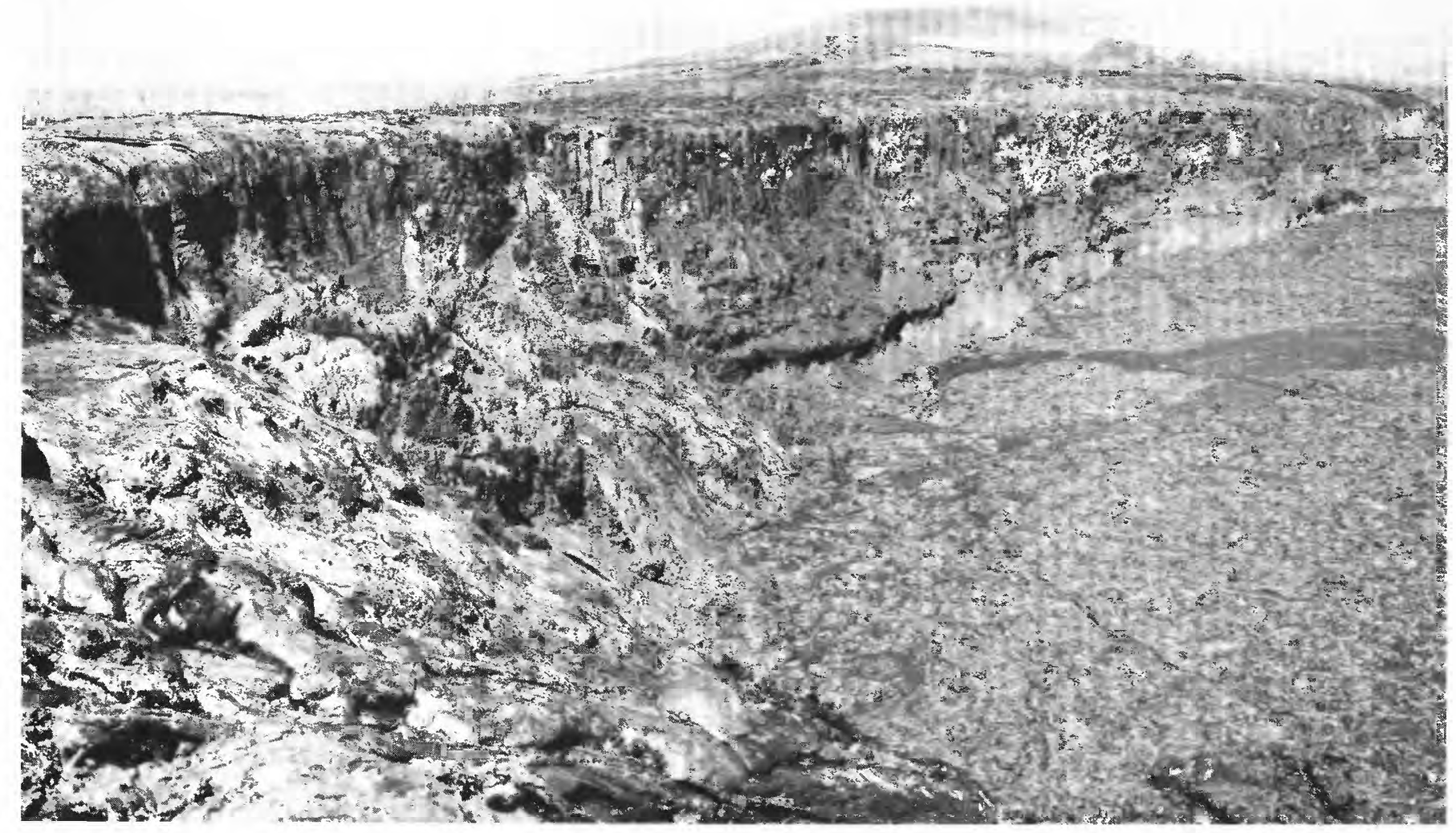

FIGURE 18.-View east from northwest lip of Alae Crater, August 24,1969 . Floor of crater is $34 \mathrm{~m}$ below low point on rim (to right of view), about $50 \mathrm{~m}$ below rim in center of view. Highest level of lava prior to draining event on August 4 indicated by top of drap- ery below light-colored wallrock in right half of photograph. Cones formed in February 1969 and tree-covered parasitic shield of Kane Nui o Hamo visible beyond crater.

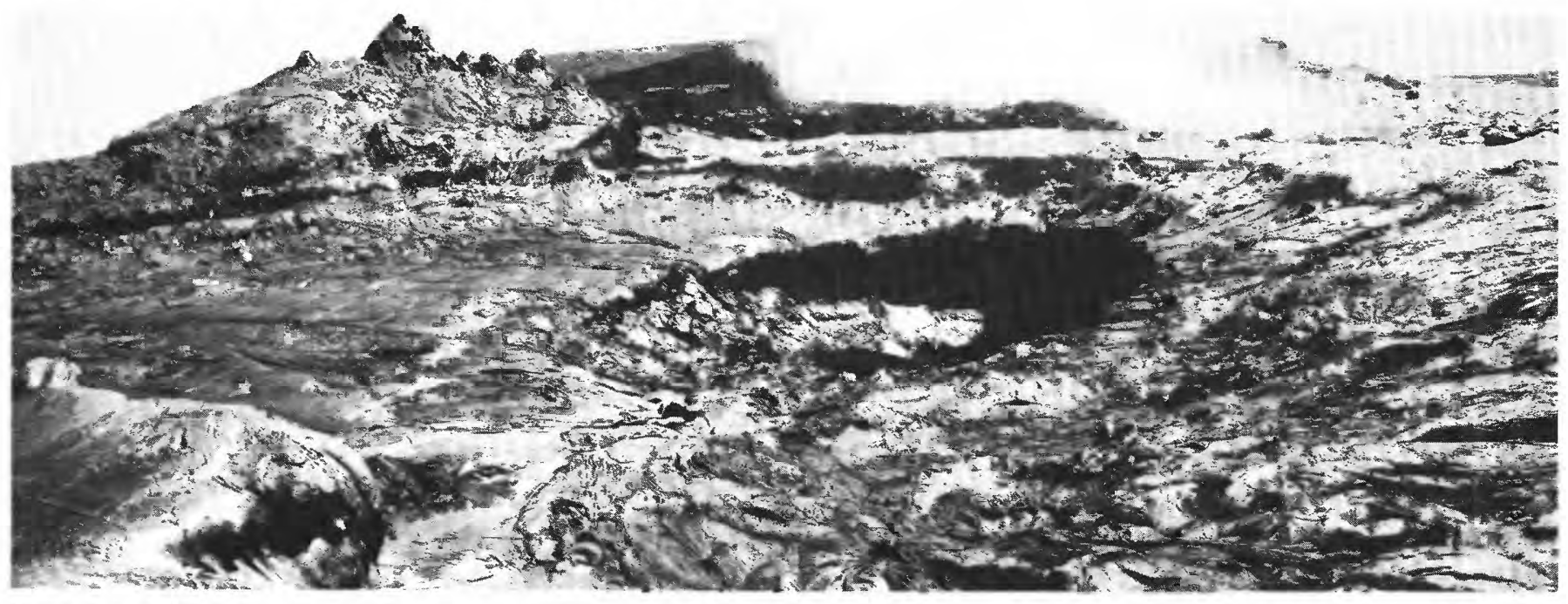

FIGURE 19.-Partly drained lava lake in eastern vent basin of Mauna Ulu, August 24, 1969. View from northernmost spatter rampart shown in figure 22 on northeast side of eastern vent ba$\sin$. Prior to August 22, surface of lake, formed on August 6, was at level of prominent ledge. Collapse pit formed above site of eastern vent on August 22, and lava drained out of the lake. Fume in background rises from western vent area. Tephra ridge forms skyline to left of fume. Diameter of collapse pit, about $10 \mathrm{~m}$. 


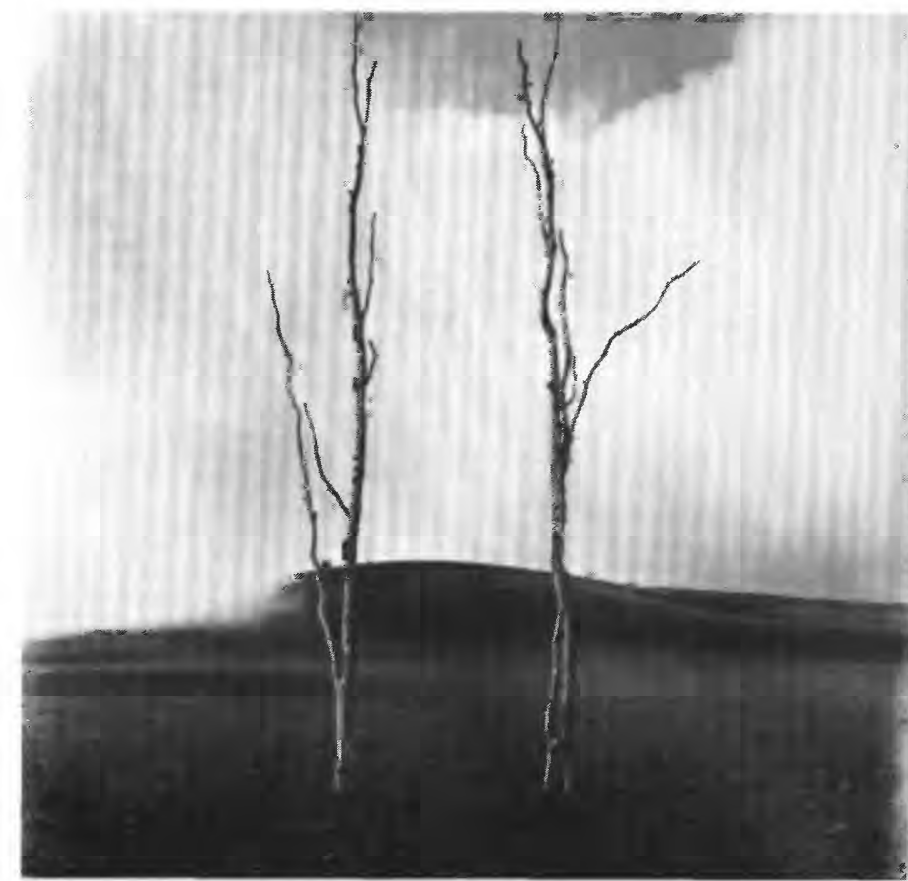

FiguRE 20.-Devastated area downwind (south-southwest) from Mauna Ulu vent area. Tephra deposit forms hill. Covered with a lush hardwood forest before the eruption, area is now buried beneath tens of centimeters of pumice. Photograph taken August 30,1969 .

compartment was glowing red within $10 \mathrm{~m}$ of the surface.

By September 1, yellow and orange encrustations of sulfur and other sublimates had formed along cracks in the spatter and pumice mound, and a light sulfur 'bloom' coated much of the ground surface. Some of the sulfur probably sublimated from fume given off by the west vent, but most was deposited from gases given off by tephra in the slowly cooling mound. Some sulfur deposits formed 4- to 7-sided polygonal patterns a few meters in diameter, possibly reflecting cooling cells or columnar joints in welded tephra. Sulfur also coated surfaces of old cones and ramparts in the vent area.

\section{SEPTEMBER 6-7, 1969}

Fume emission and harmonic tremor declined sharply at 1045 September 6 . A few minutes later, a short burst of fume and tremor occurred. We noted this from the Volcano Observatory and surmised a resumption of the gas-piston activity, correlating the decline in fuming and tremor amplitude with a rising lava column and their increase with vigorous drainback. This surmisal was confirmed when we reached the vent area at noon.

The rise and fall cycles lasted from $25-50$ minutes, depending on the amount of rise $(15-30 \mathrm{~m})$. Lava columns in both compartments (fig. 22) participated in the cycles and were almost certainly connected at

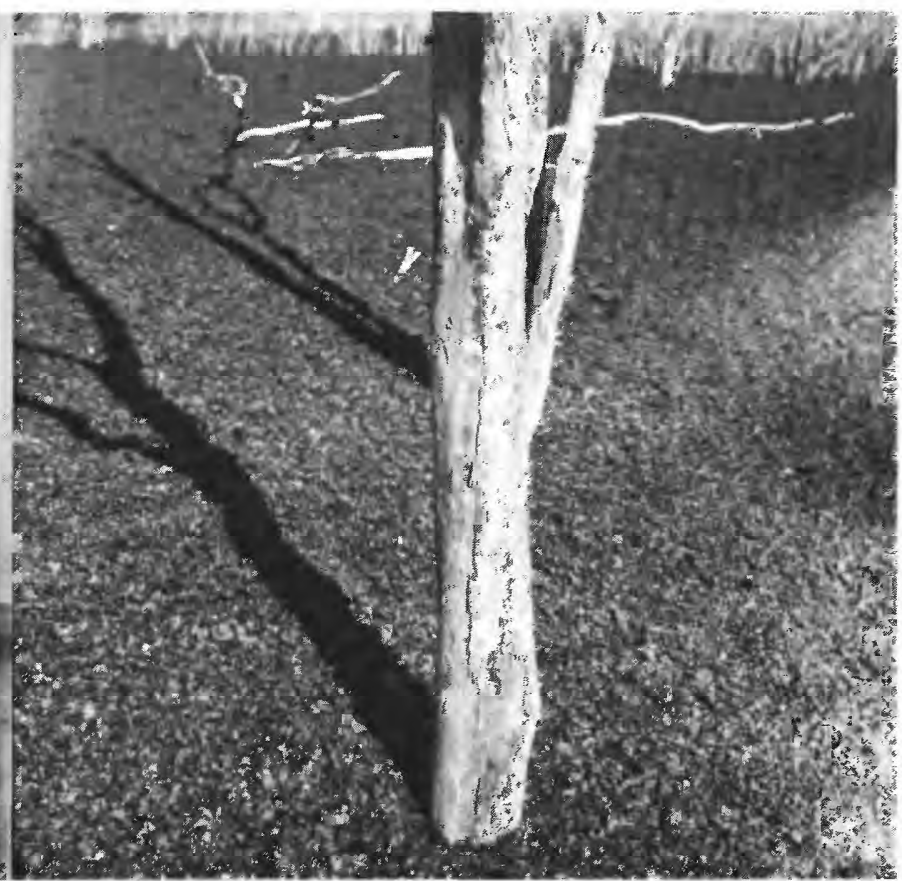

FIGURE 21.-Bark on left side of ohia tree stripped away by falling, partly wind-driven pumice. Bits of pumice embedded in wood. Devastated area $1 \mathrm{~km}$ downwind (south-southwest) of Mauna Ulu vent area, August 30, 1969.

shallow depth. In fact, during periods of drainback the lava in the eastern compartment emptied into a hole $50 \mathrm{~m}$ underneath the bridge separating the two compartments, and lava came from this hole during filling episodes. The column in the wider eastern compartment started its rise several minutes before that in the western. Once started, however, the column in the western compartment rose much faster, so that before long it was several meters higher than the column in the eastern compartment. There was a similar lag between initiation of drainback in the two compartments, but once started, the western column drained more rapidly, though with far less turbulence and spattering. A total of $2-3 \times 10^{4} \mathrm{~m}^{3}$ of lava was involved in the pistonlike action, with drainback lasting 5 minutes or less. The cyclic activity lasted all afternoon, gradually increasing in vigor so that after dusk a red glow was easily visible from Hilo, $42 \mathrm{~km}$ away.

At about 1930 , the situation abruptly changed. Harmonic tremor increased in intensity, and quickly growing fountains developed, ushering the ninth and most voluminous episode of high fountaining. All eruptive activity was confined to the western vent area. Lava jetted from both compartments and merged to produce a single mighty fountain centered over the bridge between the two compartments. At 2200 , the fountain reached $540 \mathrm{~m}$, the greatest height observed for the entire eruption, but by 2300 was 


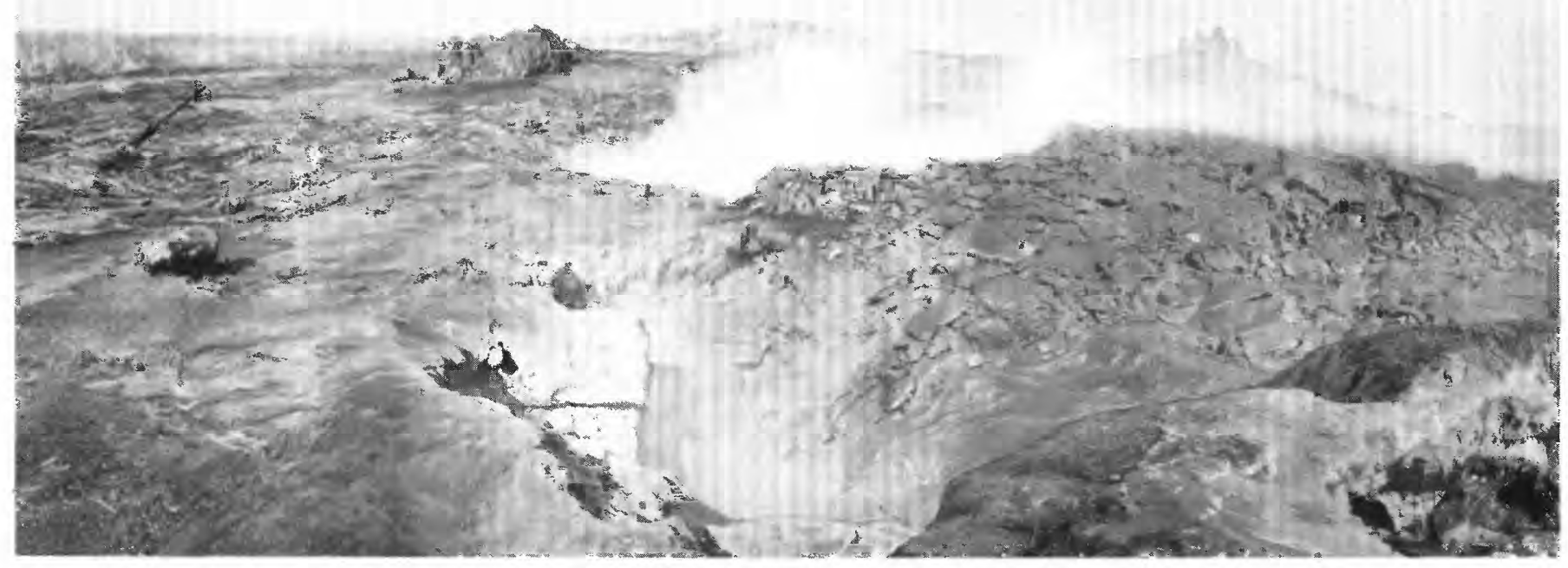

Figure 22.-Panorama looking east from cone at west end of fissure on August 24, 1969, showing newly formed western and eastern compartments in the western vent (foreground). Kane Nui o Hamo forms skyline beyond fume cloud rising from eastern compartment. Remnants of jagged spatter rampart, first

down to $400 \mathrm{~m}$. This height was maintained until 0130 September 7, when it decreased so abruptly that we thought the episode was nearly over. Fountaining from the western compartment ended at this time, and lava pooled around it drained into the inactive fissure. Fountaining from the eastern compartment unexpectedly continued, but at a reduced height of 300 $\mathrm{m}$. The fountain continued at this height, with brief ( 5 minutes or less) pulsations from about $100 \mathrm{~m}$ to $400 \mathrm{~m}$, until 0425 , when within 5 minutes it ended.

A voluminous sheet flood of lava added $4.8 \times 10^{6} \mathrm{~m}^{3}$ to the Alae Crater pool, mostly below the August 22 crust. The high lava mark of August 3-4 was reached at 0230 , lava spilled into the graben of August 4 at 0300 , and by 0415 a flow was oozing over the southeast rim of the filled crater; only $6 \frac{1}{1} 2$ months earlier this crater had been $150 \mathrm{~m}$ deep (Swanson and others, 1972). Lava flowed eastward along the floor of the graben (fig. 23), advancing about $900 \mathrm{~m}$ from Alae.

An aa flow inched its way westward from the vent area and began tumbling into Aloi Crater at 2100 . Flow into Aloi continued until the morning of September 8 , more than a day after fountaining ended; the flow covered the floor of the crater with 10 meters of jagged aa. A branch of this flow bypassed the crater, crossing the Chain of Craters Road and extending a few hundred meters farther south.

Two other flows headed south (pl. $3 F$ ). A rootless aa flow, fed exclusively by fallout and remobilized welded spatter on the flank of the tephra mound (fig. $24)$, spread about $2 \mathrm{~km}$ downslope. A larger pahoehoe flow, fed directly from the base of the fountain with only minor addition of welded spatter, flowed south- formed on June 12-13, flank inactive eastern vent, largely hidden behind fume. Arrow indicates ledge, modified by activity of August 22, from which figure 17 was photographed. Jumbled area near right edge of view is remobilized spatter that slumped toward vent from tephra cone during drainback on August 22.

ward in a fluid river for about $3 \mathrm{~km}$. This river then gradually changed within several hundred meters into aa, which continued to the top of Poliokeawe Pali and branched into two tongues, one ending below the pali, the other continuing over Holei Pali before stopping.

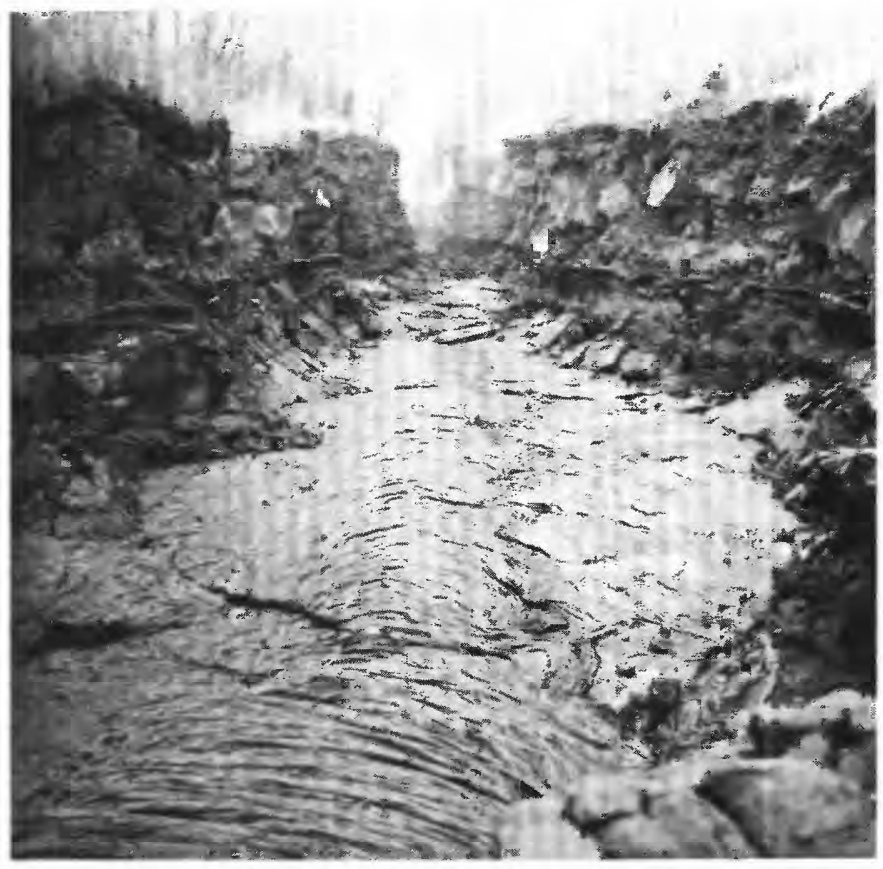

Figure 23.- View east along graben from near Alae Crater across the lava flow that entered graben from Alae on September 7, 1969. Surface of flow was higher, indicated by terrace, before degassing and draining laterally and downward into rubble-covered floor of graben. Photograph taken September 8, 1969. 


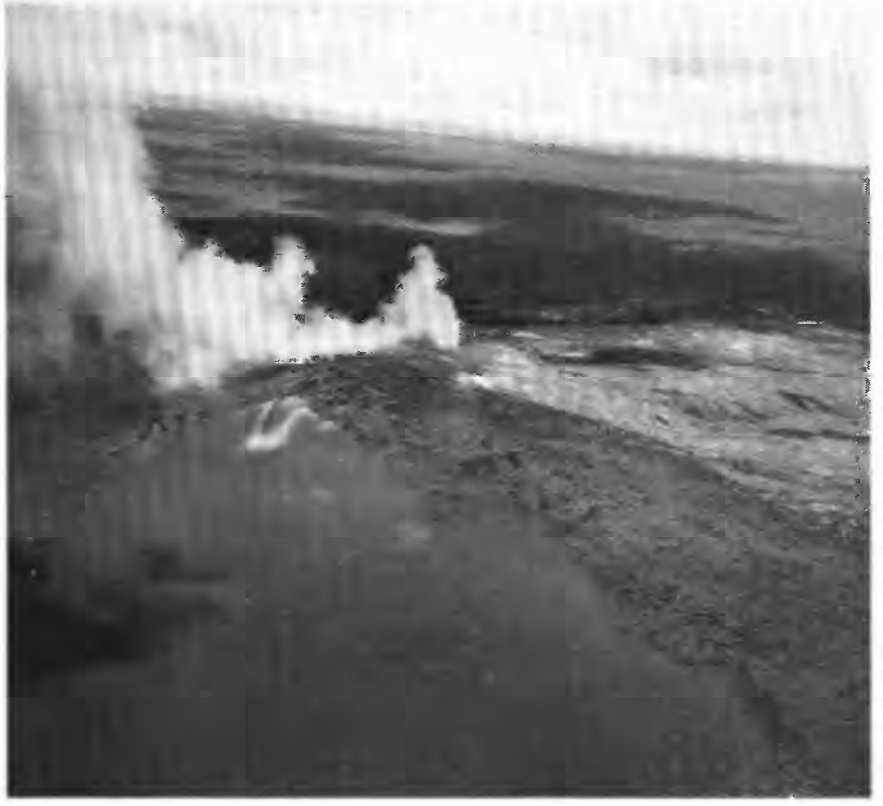

FIGURE 24.-Aerial view from the south of Mauna Ulu vent area (fuming), tephra mound (broken area below fume cloud), and pumice blanket (smooth area toward camera from tephra mound). Rootless aa flow (see text) extends toward lower right corner from source on slumped tephra mound. Subdued north wall of Alae Crater visible to right of Mauna Ulu vent area. Note sulfurous sublimates (light color) on tephra mound, particularly bordering prominent crack near surface area of rootless aa flow. Slope of Mauna Loa forms skyline. September 24, 1969.

The combined effect of unusually high fountains and strong tradewinds widened and thickened the fallout blanket of tephra and added substantially to the tephra mound, now $35-40 \mathrm{~m}$ high (fig. 25). Reticulite, an exceedingly porous type of pumice, was formed during the highest fountaining, and lumps several centimeters across were blown at least $15 \mathrm{~km}$ downward (fig. 26).

As in previous fountaining episodes, the latest lava erupted was richer in olivine than that of the early and middle stages. The episodes produced the greatest volume of lava $\left(12 \times 10^{6} \mathrm{~m}^{3}\right)$ at the second fastest average rate $\left(1.33 \times 10^{6} \mathrm{~m}^{3} / \mathrm{hr}\right)$ of the entire eruption (table $5)$. The eastern compartment had been enlarged during the episode and now was $50 \mathrm{~m}$ long by $10 \mathrm{~m}$ wide. The cone at the west end of the west compartment, which first began forming on August 15, had been totally blasted away by the fountains.

\section{SEPTEMBER 8-OCTOBER 9, 1969}

Activity much like that before the September 6-7 fountaining typified this period. The lava column, confined to the two compartments in the western vent area except for brief overflows on September 27 and October 2-3, underwent repeated rise-fall cycles. Again the lava column in the western compartment

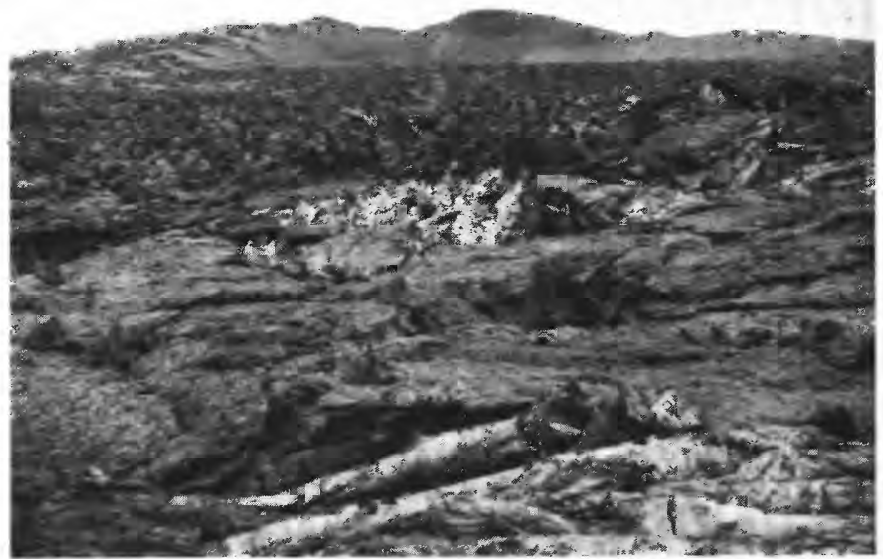

FiguRE 25.-Tephra mound and associated lower hills after fountaining of September 6-7, 1969. View is toward east from near the east rim of Aloi Crater. Mound is $35-40 \mathrm{~m}$ above its base and has a very irregular profile. Foreground consists of pahoehoe, slab pahoehoe, and aa erupted on September 6-7. Photograph taken on September 8, 1969.

began rising after that in the eastern compartment, but it ended higher. In the eastern compartment, 1$1.5 \times 10^{4} \mathrm{~m}^{3}$ of lava and gas typically rose $20-25 \mathrm{~m}$ in 15-20 min and withdrew in $4 \mathrm{~min}$ to a level about $50 \mathrm{~m}$ below the surface. Spatter ejected during particularly vigorous periods of fountaining between September 26 and 29 began to close the eastern compartment (fig. 27) and built a small cone on the bridge between the two compartments.

For some periods of several hours duration, the columns in both compartments remained at an approximately constant height, continuously bubbling. Eventually, a crust formed on each of the columns, which then began to rise as the volume of gas trapped beneath the crust increased, initiating another sequence of rise-fall activity. Gas escape from the western compartment was strong at times, lasting from several hours to several days without significant letup. A dull glow was visible at night as the wallrock was heated red by the hot escaping gas.

\section{OCTOBER 10-13, 1969}

The tenth episode of sustained fountaining started at about 0900 October 10 and lasted for 74 hours, nearly twice as long as any other fountaining episode of the eruption (table 5). This episode was characterized by low, often dome-shaped fountains and a low rate of discharge (table 5). Both compartments of the 


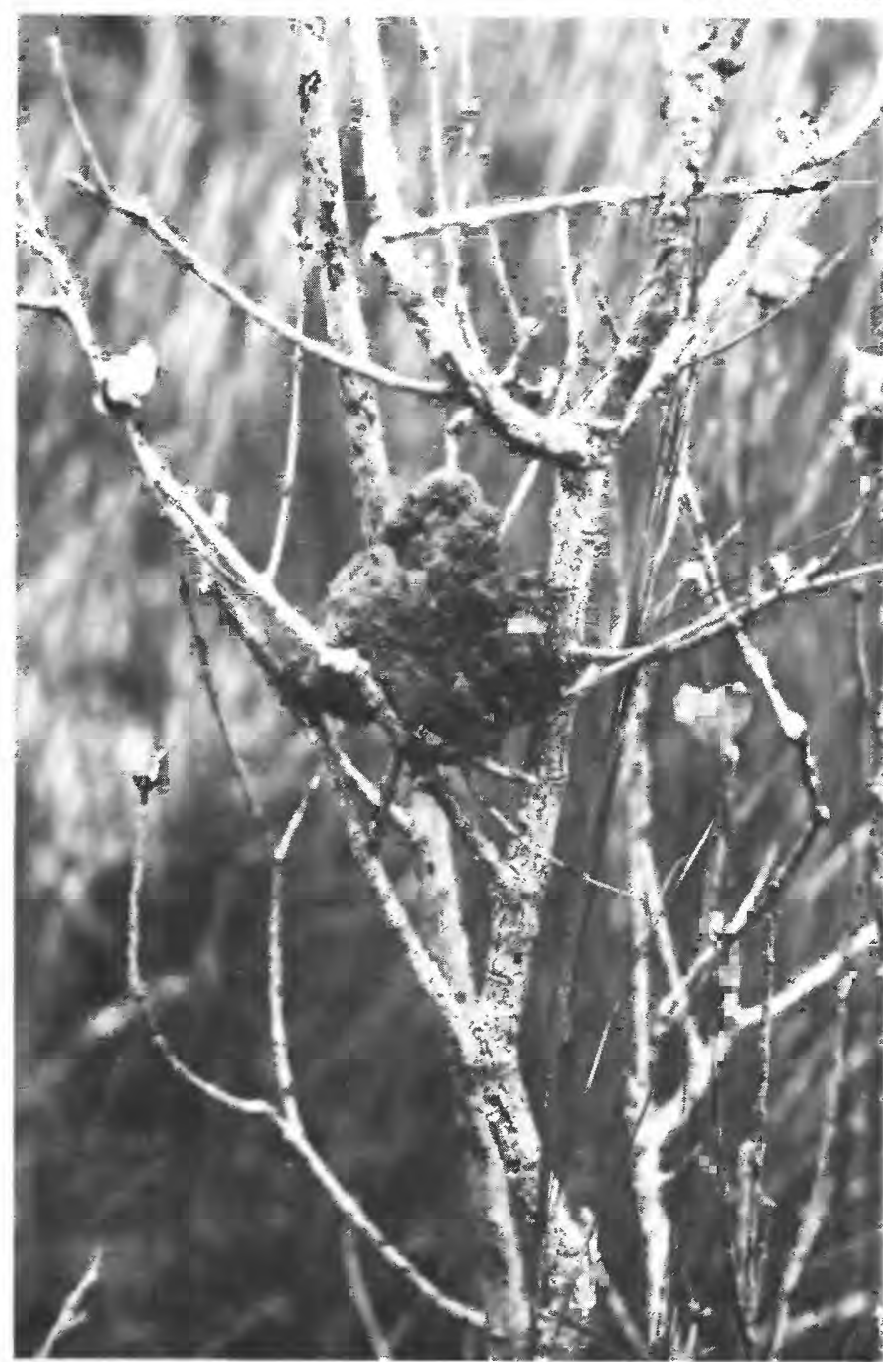

FIGURE 26.-Piece of reticulite $15 \mathrm{~cm}$ in diameter caught in ohia tree several kilometers downwind from Mauna Ulu vent area. Reticulite was erupted on September 6,1969, during period of high fountaining.

western vent area were active for most of the threeday period. A remarkably symmetrical dome fountain (fig. 28; Swanson and others, 1971, p. 15, photograph), occasionally $20 \mathrm{~m}$ high but usually half that, often welled from the eastern compartment for periods of several hours. Most of the lava from this fountain flowed away from the vent, but some formed a narrow river that poured back into the western compartment. Every few seconds, gases burst explosively from the western compartment, carrying spatter possibly derived from the lava drainback. The activity at both compartments was more episodic during the afternoon of October 12 and morning of October 13. Spells of continuous activity tens of minutes long were punctuated by brief periods when output dwindled to nothing, at which time lava ponded in the vent drained into both compartments.
Lava flows entered Alae Crater, eventually filling the shallow subsidence depression created by cooling and degassing of the September 6-7 lava (Swanson and others, 1972). Lava spilling from the crater spread $1.5 \mathrm{~km}$ south and southeast through the forest, solidifying to rather dense pahoehoe (pl. $3 G$ ). Several flows again inundated the area between Puu Huluhulu and the vent, and others advanced short distances southward. A low horseshoe-shaped cone formed around the west end of the western compartment, but tephra accumulation was small elsewhere. All of the rampart originally surrounding the vent basin was covered beneath new flows, although that part north of the eastern vent was still recognizable as new flows draped over and mimicked the old rampart. The jagged, sulfur-coated remains of the remnant on the south side of the inactive eastern vent still projected $5-8 \mathrm{~m}$ above its base.

During much of October 11-12, the input into Alae Crater was much greater than the combined rates of filling and observed outflow over the drowned crater rim. At the time we thought that some lava was draining through cracks related to the August 4 graben (Swanson and others, 1972). We now believe that the outflow over the drowned rim equaled inflow, but that most of this flow took place via small lava tubes and hence was not visible. This interpretation was reached as a result of repeated observations of how lava tubes developed later in the eruption (Swanson, 1973; Peterson and Swanson, 1974).

\section{OCTOBER 14-19, 1969}

Lava was visible in both compartments when the vent was reexamined on October 14, and cyclic gaspiston activity characterized both lava columns from then until October 19. Small overflows were infrequent, but heavy showers of spatter accompanied the many degassing events. Throughout October 19, extremely hot gases carrying Pele's hair and small bits of spatter roared from the western compartment.

\section{OCTOBER 20, 1969}

Vigorous fountaining began at 0100 October 20, ushering in the eleventh major episode of the eruption. Lava quickly filled the vent depression, spilled outward, and cascaded into Alae and Aloi Craters. By 0230 a fountain was playing $300 \mathrm{~m}$ above the western vent area, apparently centered over the west end of the eastern compartment. At 0330 , the fountain suddenly developed a strong horizontal component directed toward Puu Huluhulu (pl. $3 H$ ), where observers huddled for protection behind a stone wall. After a few minutes, the fountain gradually returned to vertical, but not before sending a heavy shower onto 


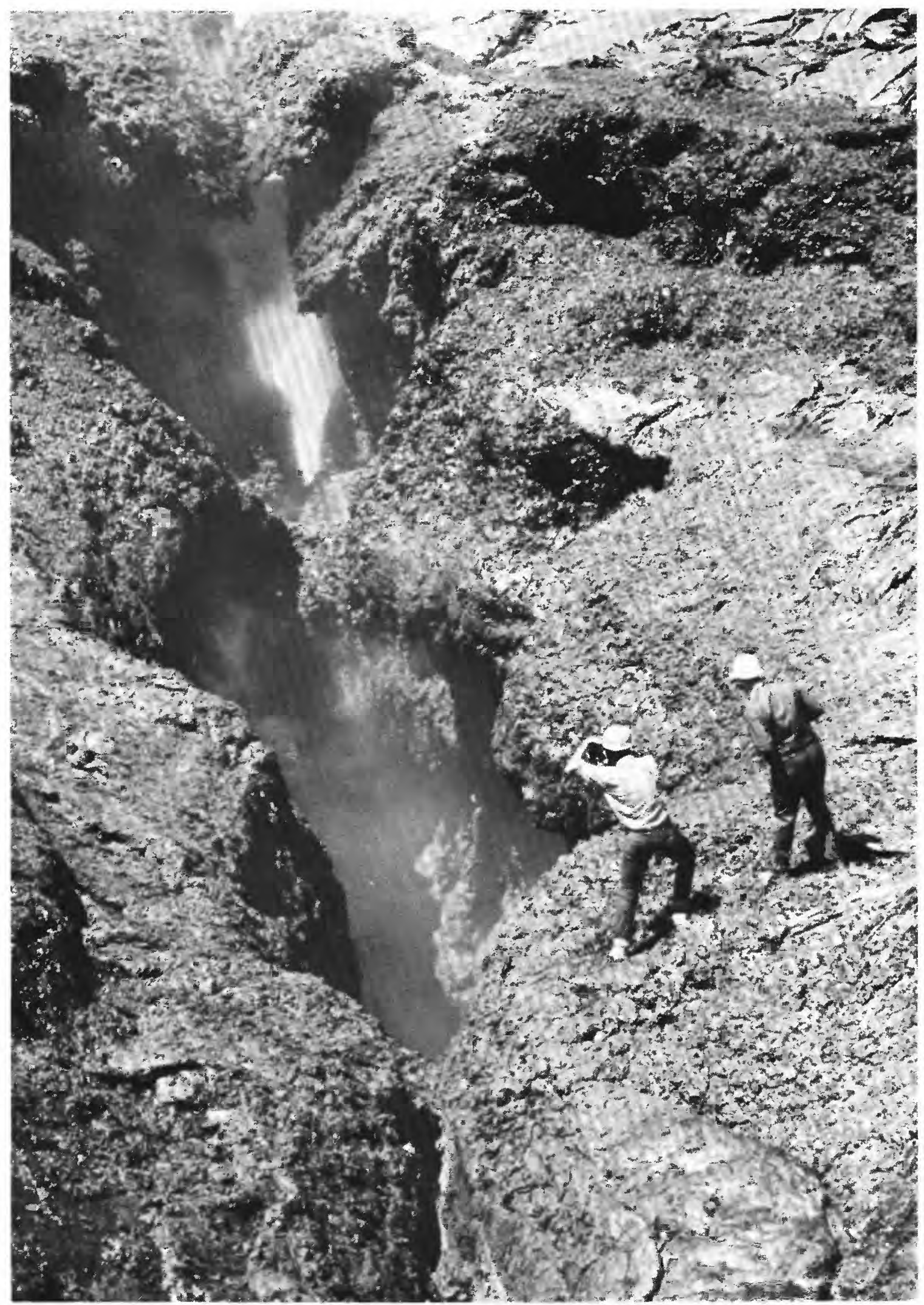

FIGURE 27.-View west along eastern compartment of Mauna Ulu vent area, September 28, 1969. Glow (white) below overhang near upper center of photograph comes from spattering column of lava. Note overhang on which men stand, built since September 26 by accretion of spatter and one overflow of fissure. 


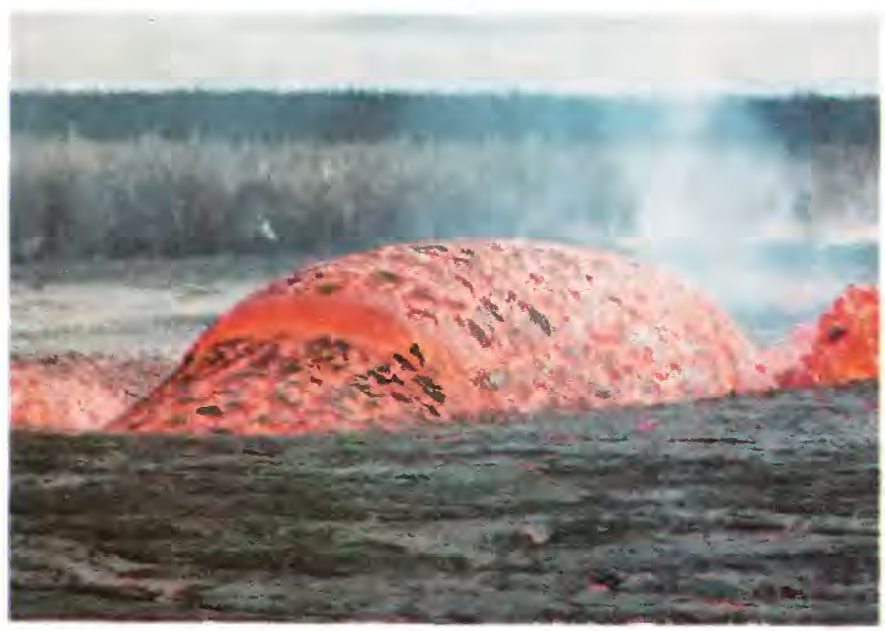

FIGURE 28.-Dome fountain about $10 \mathrm{~m}$ high erupting from eastern compartment of Mauna Ulu vent area, October 11, 1969. Left part of dome is sliding away, revealing that core is made of lava and that dome is not simply a large bubble. Mottled surface, caused by solidified crust interspersed with still-liquid lava, is typical of dome fountains. Photograph by J. B. Judd. the lower flank of Puu Huluhulu, where the spatter welded into a coherent mass that slid a short distance down the steep slope leaving slump scars (fig. 29).

This frightening interlude was probably occasioned by collapse of the bridge between the two compartments, temporarily choking the vent and deflecting the fountain jet toward one side. As the obstruction cleared, the fountain righted itself. Large volumes of spatter and pumice were blown into previously unscathed areas by strong winds generated during, and probably by, the directed fountaining. Fires started by the hot spatter enveloped forest on and west of Puu Huluhulu, and several trees in Pauahi Crater, $2.5 \mathrm{~km}$ west of the vent, were set aflame by falling pumice. Vehicles parked in normally safe locations were sandblasted and their windshields broken by the thick, wind-driven fallout.

Most of the lava went into two flows, both of which changed from pahoehoe to aa, then cascaded over Poliokeawe and Holei Palis before coming to rest (pl. $3 \mathrm{H}$ ). One of the flows followed preexisting channels

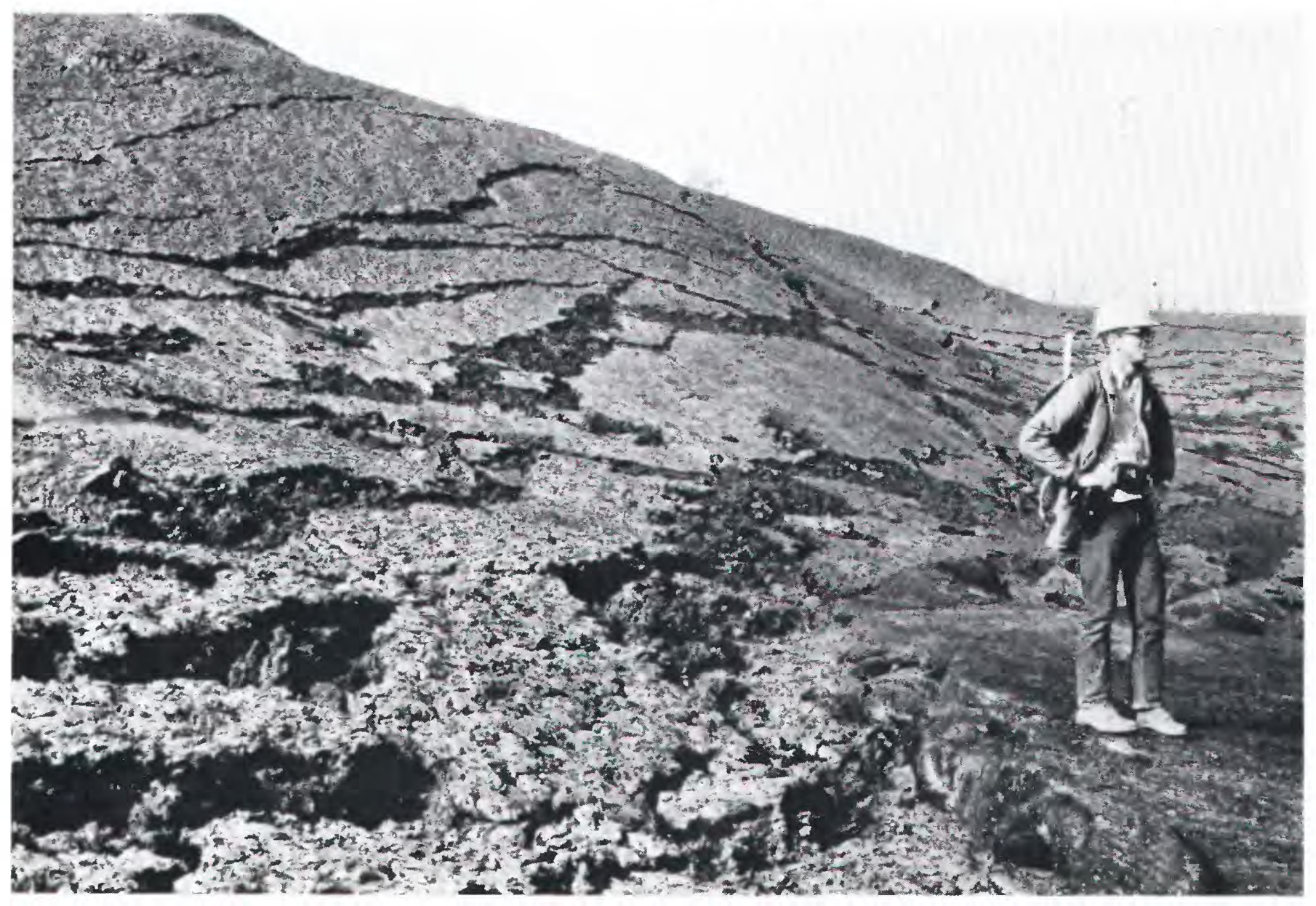

Figure 29.-Slump scars in welded spatter on south flank of Puu Huluhulu, November 1969. Spatter fell during vigorous directed fountaining on October 20, accumulated while still hot, and welded together to form a coherent fluid mass, which then slumped down the steep slope. 
southward from the vent. The other was routed through the filled Alae Crater before making its way across forest land, endangering the Chain of Craters Road (pl. $3 H$ ) and plunging over the steep cliffs. A smaller but still voluminous flow spread $3 \mathrm{~km}$ eastward from the main vent, and a minor flow entered
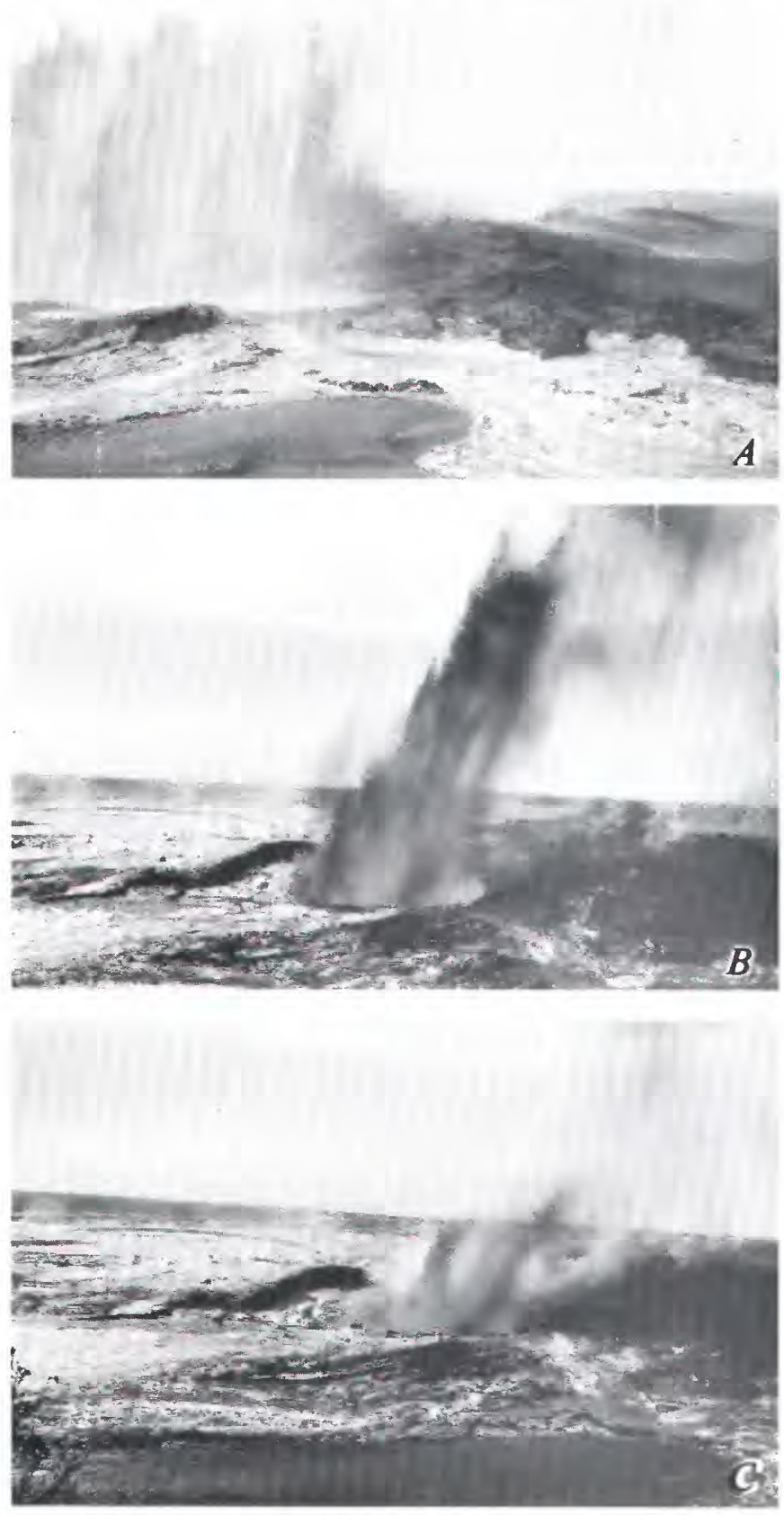

FIGURE 30.-Final minutes of fountaining at Mauna Ulu vent area on October 20,1969. A, 0800, fountains are $150 \mathrm{~m}$ high and play from both compartments in western vent area. $B, 0817$, fountain starting to die. Level of lava is already below rim of vent basin, and surging fountain is confined to western compartment. $C$, 0819 , fountain nearly dead, level of lava in vent basin lower be-
Aloi Crater. Much material was added to the tephra mound, raising its height to about $50 \mathrm{~m}$ above the preeruption base.

The height of the fountain remained between about 270 and $300 \mathrm{~m}$ from 0230 to 0615 , then gradually lowered to $150 \mathrm{~m}$ at 0640 before stabilizing (fig. 30A).
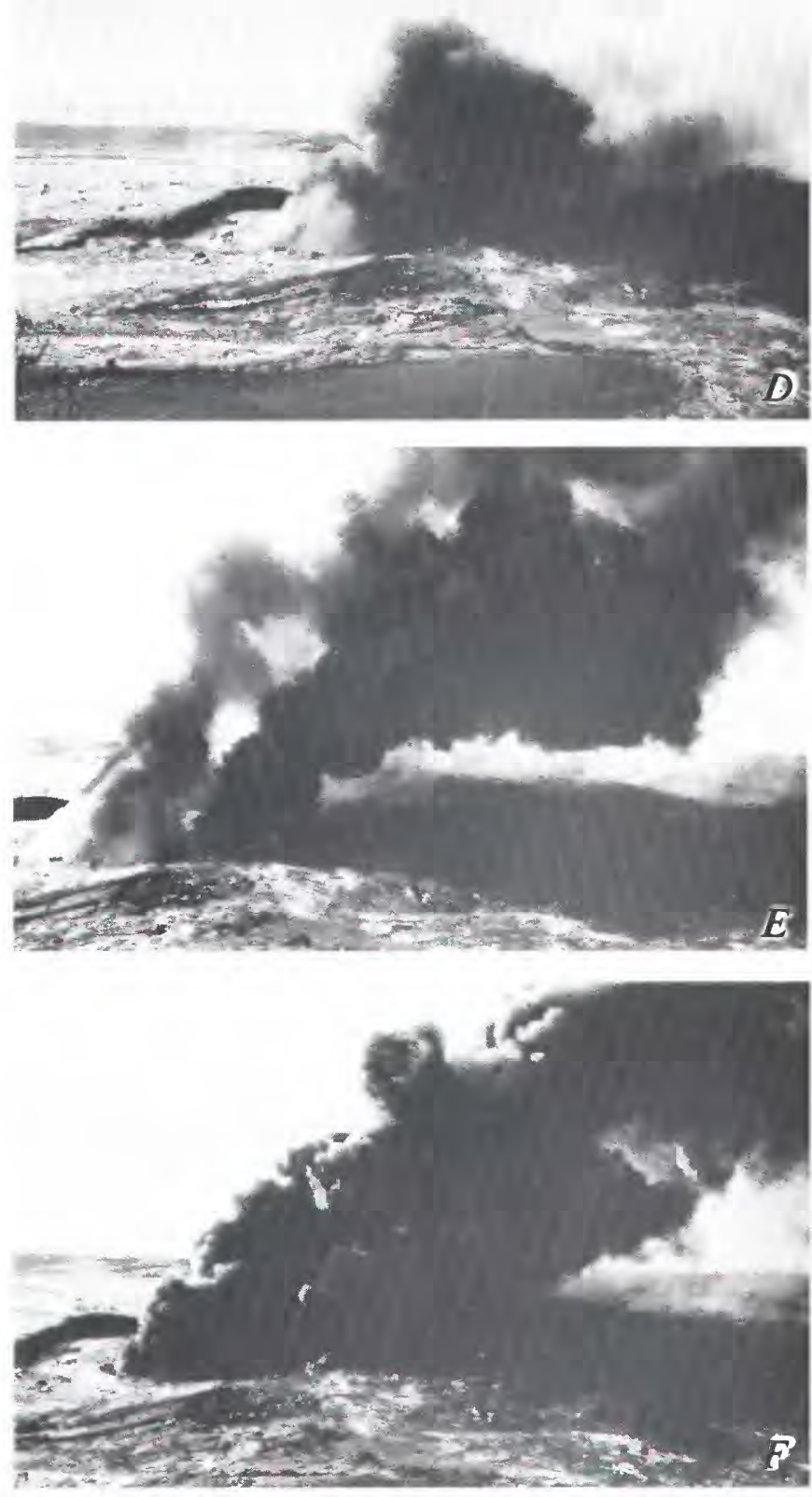

cause of drainback. $D, 0820$, fountaining ended, fume (light colored) mixed with dark cloud contains small pieces of solidified crust of draining lava. $E$, 0821, final surge of fume. $F, 0823$, dark, fragment-laden cloud issues from entire width of western compartment. Views from summit of Puu Huluhulu. 
Fountaining fell off very abruptly at 0817 , and three minutes later no molten lava issued from the vent (fig. $30, B-F)$. The fountain surged as it rapidly diminished (fig. $30 B$ ), each surge lower than the one before. As output decreased, lava pooled in the vent basin began pouring down the fissure, carrying large plates of solidified crust with it. Pulsating jets of gas from the west end of the fissure propelled small fragments of this dark crust back out of the vent and high into the air, forming an ominous black cloud (fig. $30, D-F$ ) that lasted several minutes until strong gas discharge stopped.

Weak spattering lasting about two hours occurred from two short fissures east of the main vent area while fountaining was at its peak (pl. $3 H$ ). One fissure was between 200 and $300 \mathrm{~m}$ from the main fountain in an area active on August 22. The other fissure was just northwest of Alae Crater, along the general trend of the May 24, 1969 fissure system (pl. 3A). This was the farthest from the Mauna Ulu vent area that lava had erupted since May 24, except for the isolated fissure east of Napau Crater on August 4-11.

Three wide cracks with a total opening of $30-50 \mathrm{~cm}$ cut across the reconstructed road $225 \mathrm{~m}$ west of Aloi Crater sometime between 0415 and 0615 , stopping traffic to the crater. The cracks formed in a zone 5-75 $m$ south of the trace of the May 24 fissures.

About $10.5 \times 10^{6} \mathrm{~m}^{3}$ of lava was erupted in little more than $71 \frac{1}{4}$ hours, a rate of $1.45 \times 10^{6} \mathrm{~m}^{3} / \mathrm{hr}$ - the highest rate of the eruption (table 5). Nonetheless, the basic configuration of the vent area remained unchanged. The bridge between the eastern and western compartments had been destroyed, but parts of its foundation remained, forming a partition $10-15 \mathrm{~m}$ below ground level. The compartments were each 5-10 $\mathrm{m}$ wide but had lost much of their identity. The jagged remains of the spatter rampart on the south edge of the east vent were completely mantled by $2-3 \mathrm{~m}$ of new flows, transforming it to a subdued, flat-topped ridge. The spatter cone at the west end of the western compartment likewise had been mantled with new lava and spatter but still retained its shape and prominence. The top of the broad mound of welded spatter and pumice downwind from the vent area was now about $57 \mathrm{~m}$ above the preeruption surface; this mound formed the highest part of the Mauna Ulu complex. Except for the mound, the new ground surface sloped very gently away from the vent area with only a slight accumulation of flows around it, for most of the lava erupted up to this time had flowed elsewhere rather than piling up to form a distinct basaltic shield. The vent area was about $25 \mathrm{~m}$ above the preeruption ground surface.
OCTOBER 21-DECEMBER 28, 1969

Lava was visible in the fissure of the western vent area on October 22, but no overflows extended beyond the area until November 12 . However, we unexpectedly discovered viscous, gas-poor pahoehoe oozing down the Kalapana Trail, $2.5 \mathrm{~km}$ southeast of Alae Crater, on October 24 (pl. $3 H)$. Further investigation showed that this lava was issuing from small tubes in the October flow, which headed in Alae. By hand-leveling from a point of known elevation, we also found that the lava fill in Alae was several meters higher than the low point on the buried rim; the fill was apparently ponded behind natural levees constructed over the buried rim. The surface of the Alae fill was saucershaped, suggesting withdrawal of lava from it. Consequently we assume that the lava flowing down the trail came from the Alae fill, which was apparently slowly draining through one or more narrow tubes (Swanson and others, 1972). This flow continued until October 27 or 28 , a full week after the last fountaining.

In the vent area, the lava column generally hovered near or at the top of the fissure during this period; little gas-piston action (fig. 31) was observed. A marked circulation pattern was apparent in the small active lake. Lava rose at one end of the fissure and flowed about $75 \mathrm{~m}$ to the other end before cascading back underground. The circulation rate was usually a few meters per minute, but occasionally, when inflow was rapid, a noticeable gradient developed on the surface of the column and flow rates increased to several meters per second. Circulation was normally east to west, but rather abrupt reversals were common. Less frequently, circulation stopped, but after a few minutes this stoppage generally led to marked withdrawal back down the vent from which the lava had been rising.

Circulation of lava typified activity in the lake throughout the eruption. We were unable to document the cause of either the circulation itself or its reversal of direction. The two most favored ideas, convection within a closed system and different rates of supply and drainback at submerged vents (open system), seemed equally likely at most times. The continuous loss of gas from the circulating lava suggests that volatiles were being added to the lake, possibly forcing convection. Perhaps both open- and closed-system circulation took place at various times during the eruption.

Pele's hair was an interesting minor product of this type of activity. Several times, a night's production blanketed tens of square meters with long strands of light brown glass, creating a scene resembling a field of newly cut grain. 
On three occasions in November (November 12-13, 16 , and 19), lava from the fissure filled the 9-m-deep vent basin and formed short-lived flows that advanced across the perched lake in Alae Crater (pl. $3 I$ ). These and numerous other active periods, typically several hours in duration, were characterized by dome-shaped upwelling of lava from the vent without much spattering (fig. $32 G$ ), as if the lava column were simply projecting $5-10 \mathrm{~m}$ above ground level. The upwelling, from both the western and eastern compartments, was broken every 10-15 minutes by brief episodes of drainback accompanied by vigorous spattering (fig. $32 A-F$ ). Drainback was localized at the east end of the fissure. The episodic upwelling and drainback seemed to be a variant of the gas-piston activity.

The spatter cone at the west end of the fissure, which began to form on October 10 , gradually became coated with sulfurous deposits following the October 20 fountaining, then on November 12 began acquiring a thick blanket of new spatter and quickly grew to a height of 10-12 $\mathrm{m}$ above the floor of the vent basin. A cone at the far east end of the fissure began forming on November 8 (fig. 31) and eventually reached a height of $12 \mathrm{~m}$ above the floor of the basin. This horseshoeshaped cone was periodically drowned by lava when the basin filled (fig. $32 G$ ); upon withdrawal, a thin layer of lava was left mantling the cone (fig. $32 E$ ). This repeated process, combined with spattering, added significantly to the height of the cone and produced a curious-looking flat roof overhanging the vent itself, leading to our informal designation, the pedestal cone (fig. $32 \mathrm{H}$ ). The pedestal cone was a prominent landmark from mid-November to December 30. Another

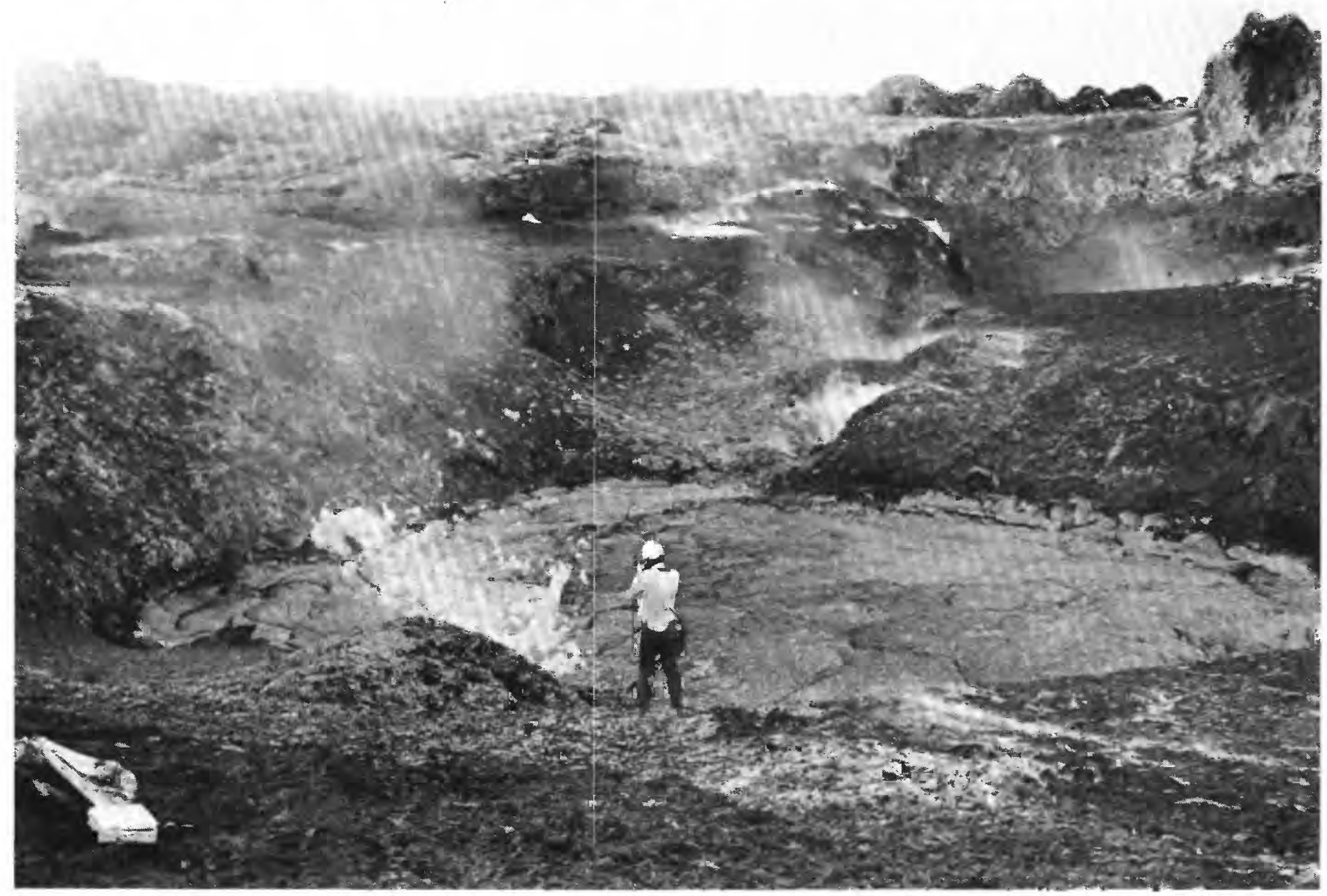

Figure 31.-View westward from east end of western vent area, November 9, 1969. Crusted pool of lava occupies part of vent basin above eastern compartment. Slight drainback of lava has just begun, indicated by lower level of pool. Spatter in front of man is generated by lava flowing back down vent. Low mound left of man is top of cone being built by spatter; this cone developed into the pedestal cone of figure $32 \mathrm{H}$. Low cone with glowing (white) interior at far end of pool is built against bridge separating eastern and western (upper right) compartments. Jagged remnant of cone at west end of western compartment in extreme upper right corner. 
spatter cone began forming on November 10 along the southwest edge of the eastern compartment; this cone, which also underwent repeated drowning episodes though it never became as high or wide as the pedestal cone, lasted only until November 21 , when it collapsed into the fissure. Other cones, built on the remains of the partition between the two compartments, lasted only a few hours before being destroyed by collapse or overflows.

On the morning of November 30 , lava fed by a low dome fountain at the west end of the western compartment flowed $80 \mathrm{~m}$ on the surface along the trace of the fissure before plunging $15-20 \mathrm{~m}$ into a seething pool at the base of the pedestal cone, now $12 \mathrm{~m}$ above the floor of the vent basin. At 1030, we watched the pool rapidly but quietly rise and blossom into a fountain 5-8 m high. This started $2 \frac{1}{2}$ days of surface activity similar to that earlier in the month, including flows into and around the site of Alae Crater. The pool was at times 9-10 m deep, washing over remnants of the old spatter rampart along the south edge of the eastern vent but not over the pedestal cone. The surface activity stopped during the night of December 2, and there was no further visible activity, except rare spattering deep in the fissure, until December 13. Fuming was heavy during this lull, and sounds of a rising and falling lava column remained audible.

Meanwhile, three new fissures had opened along the trend of the May 24 system, between 800 and $1500 \mathrm{~m}$ downrift from the Mauna Ulu vent area (pl. $3 I$ ). This activity occurred sometime between December 3 and 8 , most likely during the night of December 7-8, when a small flurry of earthquakes was recorded from the area (pl. $2 C$ ). Small spatter ramparts were built along the three fissures, each of which was about $100 \mathrm{~m}$ long and offset in a right-en-echelon sense from the Mauna Ulu fissure and from each other. Small pahoehoe flows with a total volume of $0.5 \times 10^{6} \mathrm{~m}^{3}$ spread short distances from the fissures.

Surface activity at the Mauna Ulu vent resumed on December 13 and continued for five days, with lava again entering Aloi Crater and adding to the surface of the complex lava lake filling Alae Crater. Again the fountains were commonly dome shaped, and lava in the vent circulated from west to east during pauses between fountains and drainbacks. The volume rate of circulation ranged from $500-1,000 \mathrm{~m}^{3} / \mathrm{min}$ on December 14 to $1,000-1,500 \mathrm{~m}^{3} / \mathrm{min}$ on December $15-18$, as determined from the dimensions of the basin between compartments through which the lava moved. From December 19 to 28 , the top of the lava column was deep within the fissure, sometimes out of sight, although its presence was confirmed by a reddish glow reflected from glassy spatter clinging to the fissure walls.

In summary, activity after the high fountaining episode on October 20 greatly changed the shape of the Mauna Ulu edifice. The vent area itself had increased in elevation by about $15 \mathrm{~m}$. The top of the spatter cone at the west end of the fissure, the highest and most prominent point in the vent area, was about $56 \mathrm{~m}$ above the preeruption surface and only $1 \mathrm{~m}$ below the top of the tephra mound downwind from the vent area. The last remaining traces of the old spatter rampart along the south edge of the inactive eastern vent area were almost entirely obliterated beneath younger flows. All these changes contributed to the development of a shieldlike form centered at the active (western) vent area of Mauna Ulu, though the edifice remained markedly asymmetric owing to the broad tephra mound extending south-southwest from the vent area.

\section{DECEMBER 29-30, 1969}

Lava returned to a high level in the fissure at midday December 29, and periodic overflows began soon thereafter, accompanied by gas-piston action (fig. 33). Weak and pulsating activity continued throughout the night but gave way to continuous, gassy fountains at 0500 December 30, when the twelfth and last episode of vigorous fountaining began. Fountain height was rather steady at $30 \mathrm{~m}$ until 0745 , when it started to increase, reaching a maximum of $75 \mathrm{~m}$ at 0820 . Five minutes later, the fountain ended abruptly. Flows spread eastward across the December fissures, southeastward across Alae Crater, and westward to Aloi Crater, where majestic lava falls plunged $25 \mathrm{~m}$ into the crater, forming a new lake (fig. 34).

Harmonic tremor continued after the fountain stopped, and soon thereafter, we observed weak spattering events and occasional overflows from our vantage point on Puu Huluhulu. This activity slowly picked up, and at 0950 flows were advancing in all directions from the vent area. Strong fountaining resumed at 1000 , growing from $25 \mathrm{~m}$ to $55 \mathrm{~m}$ high in 45 minutes. Fountain height increased in spurts to $150 \mathrm{~m}$ at 1400 , then quickly sprouted to $240 \mathrm{~m}$ at $1430,275 \mathrm{~m}$ at $1500,350 \mathrm{~m}$ at 1525 , and $390 \mathrm{~m}$ at 1540 . Pumice probably erupted at this time was collected the next day from the coast highway $13 \mathrm{~km}$ southeast of Mauna Ulu, and spatter fell $600 \mathrm{~m}$ upwind on the summit of Puu Huluhulu. The fountain then declined to about $225 \mathrm{~m}$, where it stayed until just before the end of activity at 1830 . When viewed from Aloi Center, the fountain appeared to fan outward on both sides of the fissure and, together with the thick envelope of fall- 

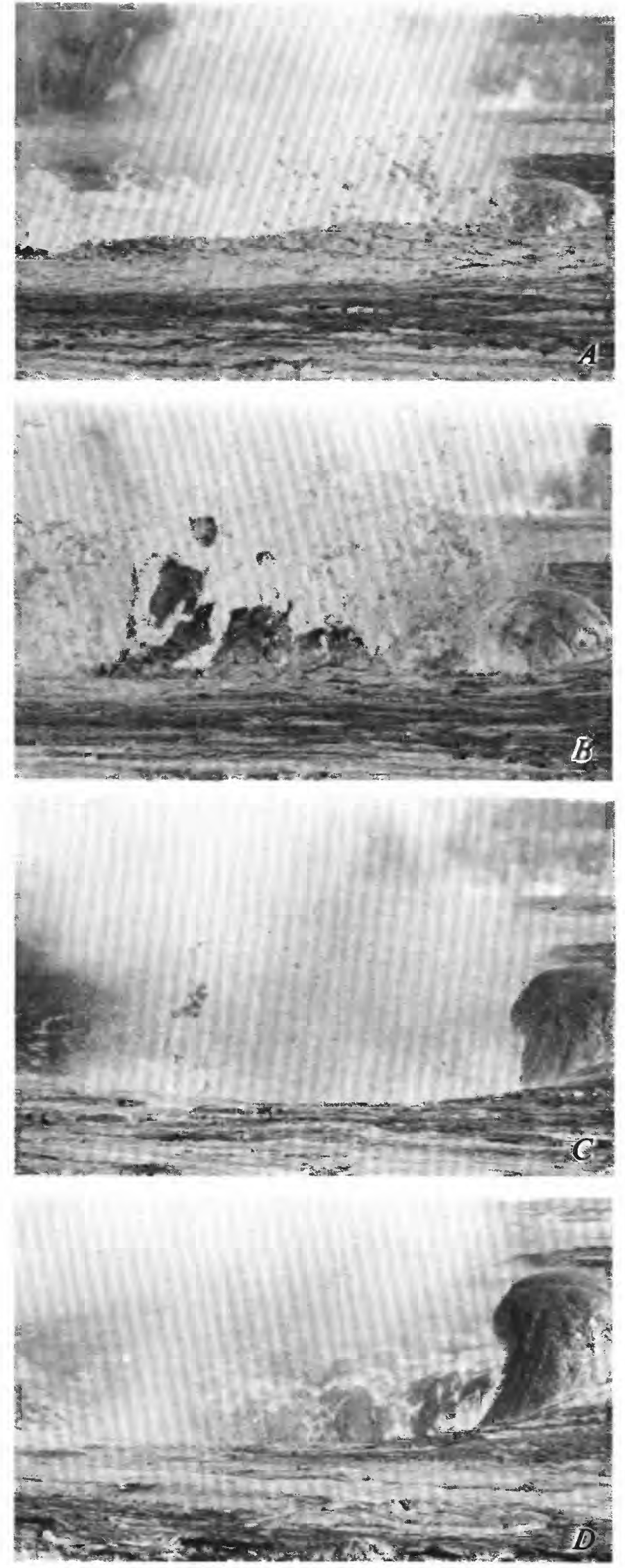
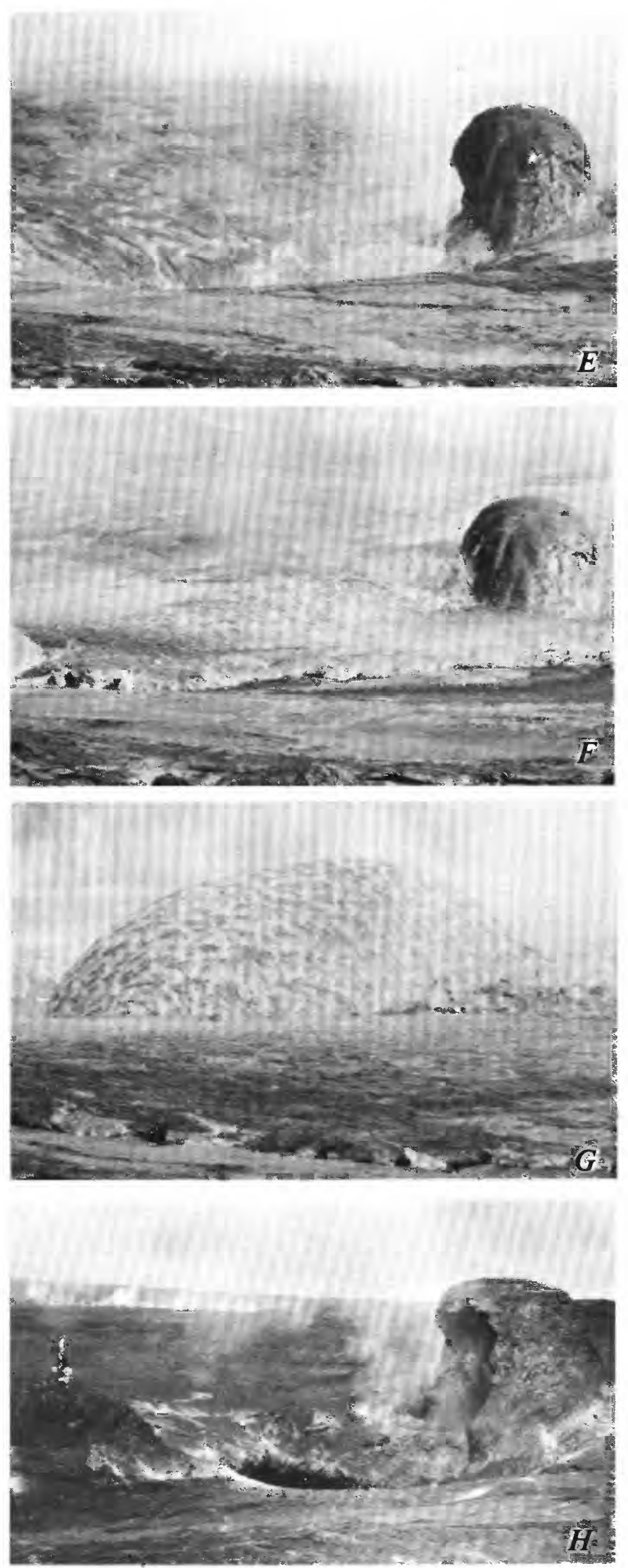
out, reached a measured breadth of $500 \mathrm{~m}$ on several occasions (frontispiece).

The largest flow generated by the fountain spread eastward, reaching the northwest base of Kane Nui o Hamo (pl. $3 I$ ), $3 \mathrm{~km}$ distant, by 1415 . Another voluminous flow coursed into Alae, plunged beneath the crust of the perched lava lake, and drained over the south rim of the crater. Subsequent leveling showed that $24 \mathrm{~m}$ of basalt now overlay the buried southeast rim of Alae (Swanson and others, 1972). Most of the area between the vent and Puu Huluhulu was inundated by slowly moving sheet floods, which heated the air so much that complex wind circulation patterns were created, including forceful whirlwinds, similar to but often larger than those described at Etna (Whitford-Stark and Wilson, 1976); the winds tore large fragments of crust from the flows. A vigorous flow poured into Aloi Crater, which filled at a rate of $0.2 \times$ $10^{6} \mathrm{~m}^{3} / \mathrm{hr}$ to within $21 \mathrm{~m}$ of the rim until 1500 , when-a dam near the fountain temporarily stopped most of the flow (frontispiece). The dam broke at 1550, and the crater resumed filling at the same rate as before. Filling finally stopped at 1900 , one-half hour after fountaining ceased, ending with the new floor within $13 \mathrm{~m}$ of the crater rim; subsequent cooling and degassing caused the floor to subside $2-3 \mathrm{~m}$.

About $11 \times 10^{6} \mathrm{~m}^{3}$ of lava was erupted during the December 30 episode, more than 90 percent after 1000 (table 5). Much new pumice and spatter was added to the tephra mound (fig. 35). The vent area underwent large changes, most notably by enlargement of the fissure to a gaping orifice $130 \mathrm{~m}$ long and $35 \mathrm{~m}$ wide. No remnant of the partition between the two former compartments remained. Most of the pedestal cone was destroyed, leaving only a low mound above an embay-

FIGURE 32.-Drainback and refilling of eastern compartment of Mauna Ulu vent area on November $13,1969,(A-G)$, and compartment after activity had ceased on November $14,1969(H)$. A, Drainback begins, exposing top of pedestal cone (see text) on right, which has been drowned by the pooled lava. $B$, Vigorous spattering takes place as level of lava drops. $C$, Same as $B$, except lava has withdrawn farther in compartment and spattering is finer, almost a spray. $D$, Spattering has stopped, and crusted lava pours into compartment. $E$, Lava continues to drain into compartment, but top of rising column of lava is visible at base of cone. $F$, Rising lava column fills compartment and projects slightly above lip of compartment. $G$, Dome fountain projects above lava spilling outward from compartment; note that lava covers top of pedestal cone. Time between $A$ and $E, 2$ minutes; between $E$ and $G, 3$ minutes. $H$, Eastern compartment and pedestal cone on November 14, viewed from southwest from slightly different location (chiefly lower) than $A-G$; low cone that man stands on is just to left of view in $A-G$. ment at the east end of the fissure. The cone at the west end of the fissure stood higher by several meters because of spatter accumulation. This was the last time strong, persistent fountaining occurred at Mauna Ulu. Whether this is related to the enlargement of the fissure from a relatively narrow fissure to a much wider vent is an interesting speculation.

\section{SECOND STAGE OF ERUPTION}

\section{DECEMBER 31, 1969-APRIL 8, 1970}

The top of the lava column fluctuated from a few meters to $60 \mathrm{~m}$ or more below the ground surface for most of this period. Only rarely did the column remain within $10 \mathrm{~m}$ of the surface for longer than a day or two. The walls of the vent periodically failed, presumably when suppport was withdrawn because of the low level of lava, and by February 7, the vent had widened to $40 \mathrm{~m}$ by collapse. Thick fume generally obscured the lava when it was deeper than $20-30 \mathrm{~m}$, but bubbling sounds always confirmed its presence at depth. A slow but steady circulation pattern, usually from east to west but sometimes reversed, was often evident whenever lava was visible. Periodic rises, drainbacks, and low fountains of short duration took place from time to time within the fissure. The amplitude of rise and fall was much less than during the preceding months, but the volume involved, 1-2 $\times 10^{4} \mathrm{~m}^{3}$, was equivalent because of the much greater surface area of the lava column.

The vent overflowed only six days during this period, January 25 and 30, February 13-15, and March 1. These flows entered Aloi Crater and extended north to Puu Huluhulu and downrift for $2 \mathrm{~km}$ (pl. $3 J)$, covering most of the December 5 spatter cones that were not previously inundated. The volume of these flows was about $3 \times 10^{6} \mathrm{~m}^{3}$. Many of the smaller flows advanced only $200-300 \mathrm{~m}$ from the vent, adding substantially to what by now was a distinct but low shieldshaped edifice. By March 1, this broad shield, nearly $60 \mathrm{~m}$ high above the pre-eruption base but much less above the apron of new flows that surrounded it, had overrun a considerable part of the pumice and spatter cone built previously.

The cone at the west end of the fissure, initially formed on October 10,1969, continued its growth during periods of spattering accompanying drainback of overflows. The cone partially collapsed from time to time and assumed a craggy appearance, but it was still $8 \mathrm{~m}$ higher than the rim of the vent at the end of March. Another spatter cone formed on February 11 at the east end of the fissure and grew to a height of 6$8 \mathrm{~m}$ by April. 


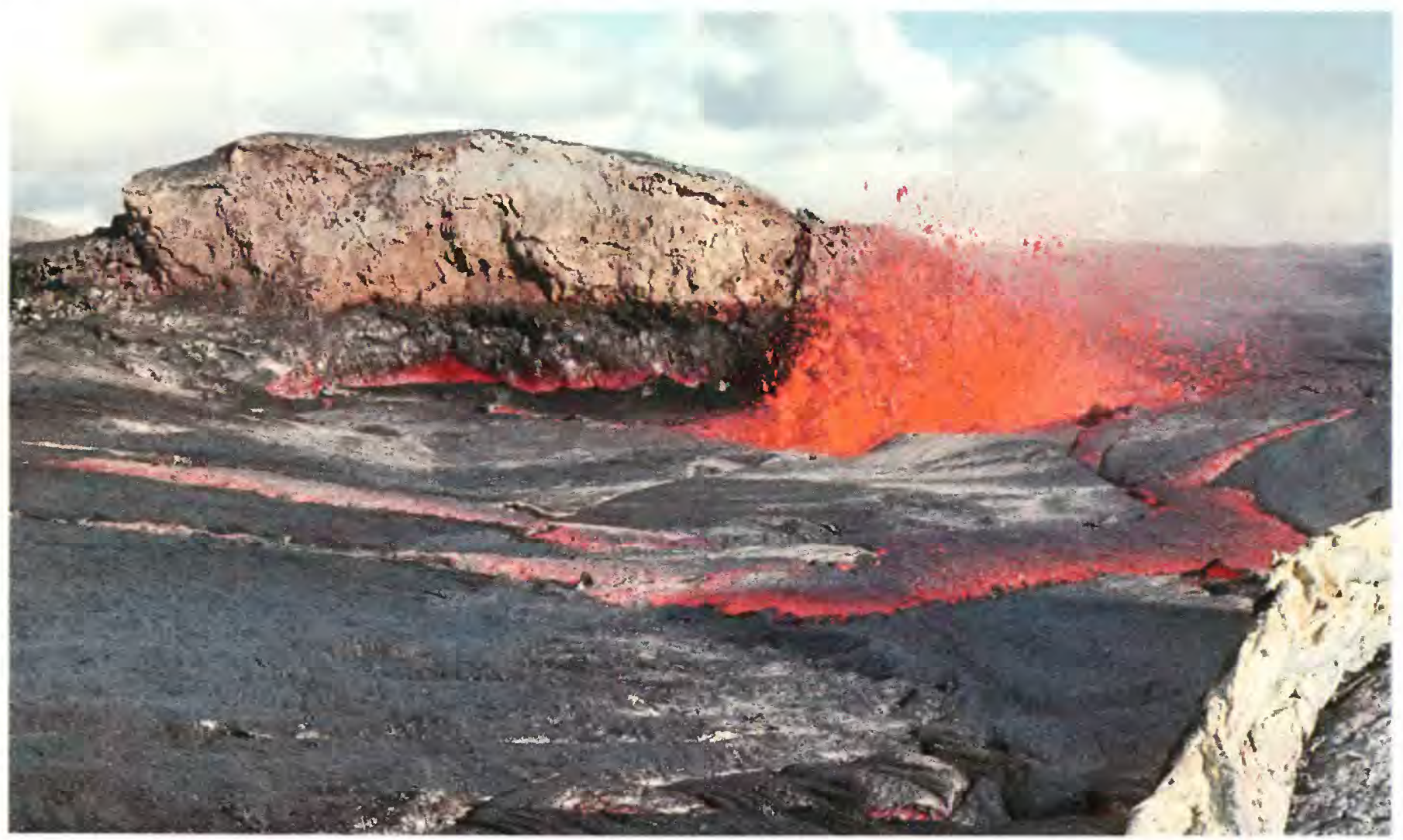

FIGURE 33.-Drainback sequence at Mauna

A, Lava has just started to drain down vent from its high level, indicated by black coating on sublimate-coated cone. Spattering typically accompanied drainbacks.

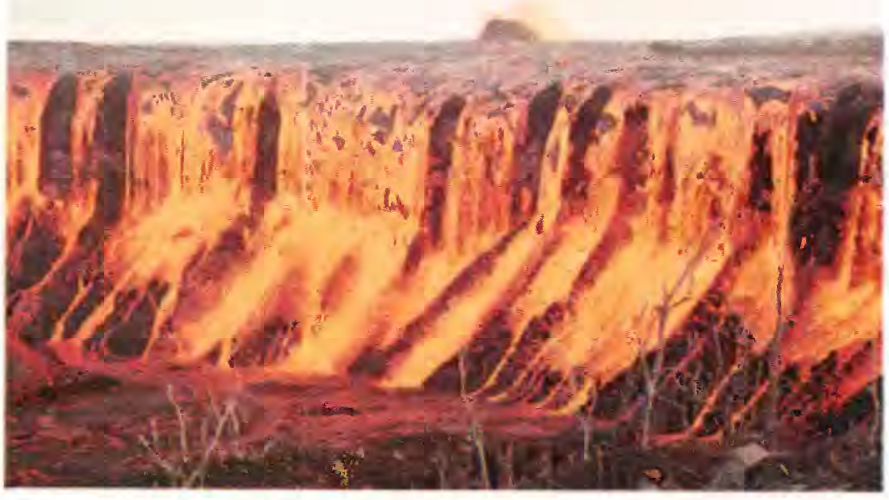

FIGURE 34.-Lava falls into Aloi Crater, about 0730 December 30 , 1969. Lava advances from Mauna Ulu vent area, $600 \mathrm{~m}$ away, where 30-m-high fountain is visible. Falls are about $25 \mathrm{~m}$ high and plunge beneath crust floating on a rapidly deepening lava lake.

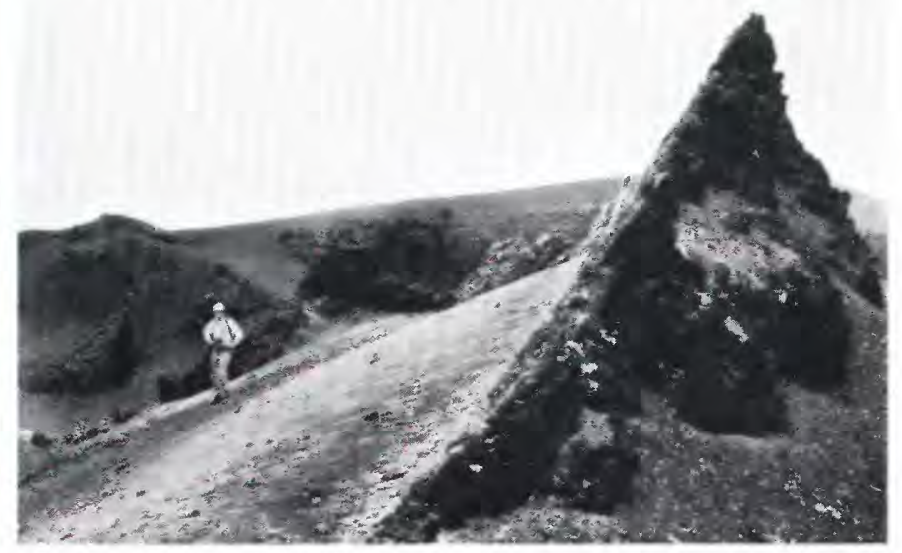

FIGURE 35.- Tilted slabs of welded spatter blanketed by pumice and spatter erupted on October 20 and, mainly, December 30, 1969. Note contrast between chaotic terrain in foreground and undisturbed bedding in tephra in background. The chaotic area is at head of rootless aa flow generated on September 6-7, 1969 (fig. 24). Photograph taken in March 1970. 


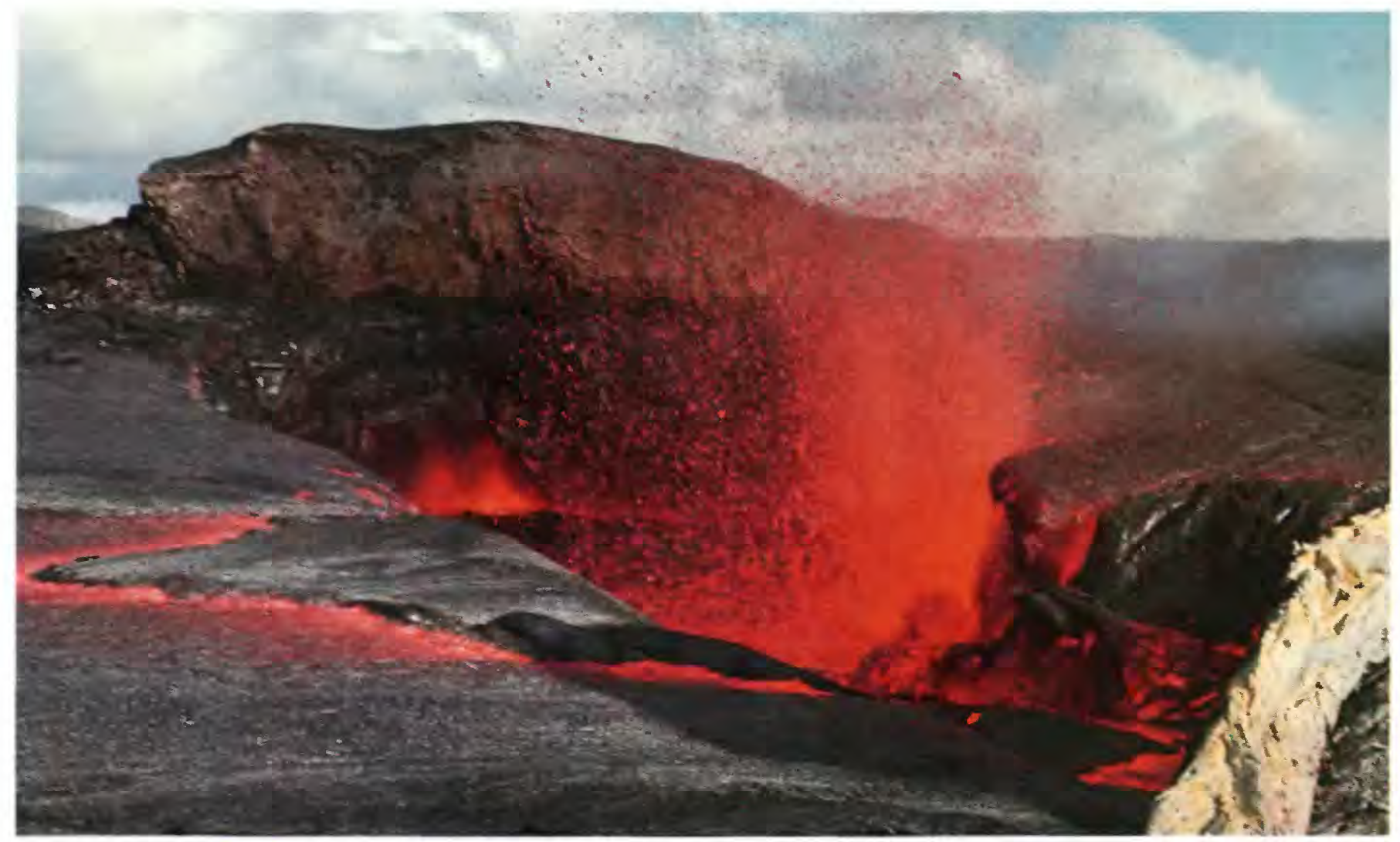

Ulu vent area, December 29, 1969.

$B$, Drainback nearly completed, and dark crust on flow plunges over rim into fissure; rapidity of cooling indicated by color gradation around edge of plate of crust slipping off slower-moving liquid part of flow. Level of lava in fissure in $B, 10-12 \mathrm{~m}$ lower than high lava mark. Cone in background is relict of pedestal cone (fig. $32 \mathrm{H}$ ).

A thin roof, built outward from the fissure walls by accreted spatter, began to form in late February. Overflows on March 1 added to the roof and sealed the fissure for $25 \mathrm{~m}$ eastward from the temporarily inactive west cone. The roof continued to grow eastward as spatter and crust from the rising and falling lava column were added to it. By March 18, the fissure was roofed over, except for an opening $8 \mathrm{~m}$ in diameter. The roof remained largely intact until the night of April 8-9.

\section{APRIL 9-MAY 14, 1970}

The nature of the eruption changed on the morning of April 9, when low fountaining began from a new set of fissures cutting Aloi Crater and the adjacent flank of Mauna Ulu (pl. $3 J$ ). The outbreak was not discovered until 0830 , when the floor of the crater was almost completely covered, but tilt and seismic data (not shown in pl. 2) suggest that ground cracking began between 0400 and 0500 and eruption about 0600 .
By 0830 , small puddles of lava had erupted from a fissure across the Chain of Craters Road near the tourist overlook (fig. 36) and from two right-offset fissures 200-250 m farther west. Fountains within Aloi and cascades down the east wall combined to fill the remaining $15 \mathrm{~m}$ of the crater by 1010 . A flow spilled over the rim (fig. 37) and spread southward. Twelve hours later, this flow reached its maximum extent at the base of Holei Pali, $7.5 \mathrm{~km}$ distant (pl. $3 J$ ).

Observations between 0900 and 0930 revealed molten, gas-poor lava at depths of a few meters to several tens of meters within a wide crack west of the westernmost vent. The lava slowly moved westward in the crack, and at 1145 reached a point about $300 \mathrm{~m}$ beyond the westernmost vent. No lava was seen beyond this point. We could not determine if the lava was at the top of a dike intruded from below or was part of a flow channeled by the crack away from the westernmost vent.

The zone of ground cracking also migrated west- 


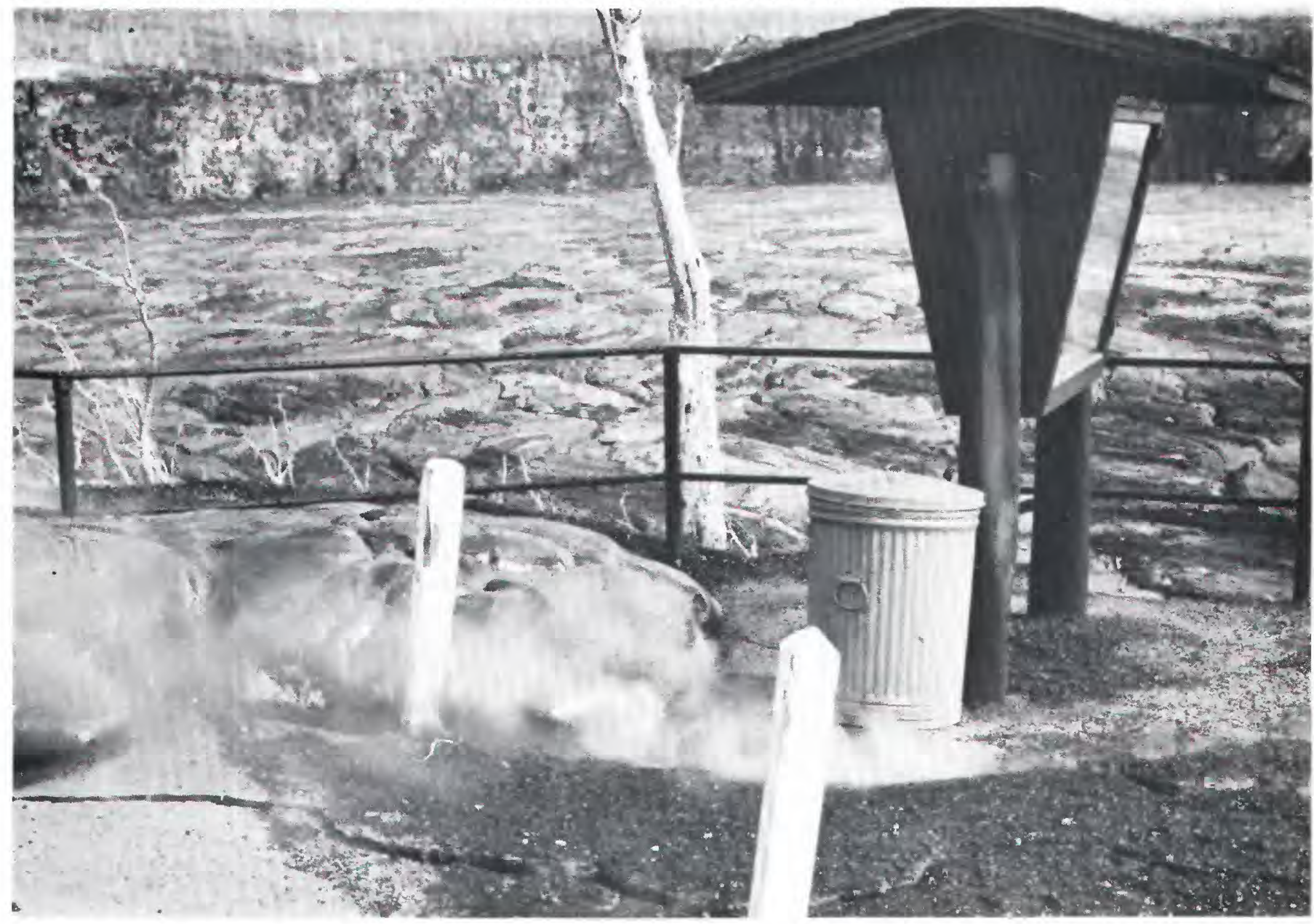

FIGURE 36.-Lava puddle approaches display case at tourist overlook at Aloi Crater, 0900 April 9, 1970. Crater is not yet filled; puddle was erupted from fissure outside crater. Note new crack cutting pavement between the two posts.

ward, accompanied by emission of fume. At 0935, the western limit of cracking was about $340 \mathrm{~m}$ from the westernmost vent; at $1005,380 \mathrm{~m}$; at $1228,945 \mathrm{~m}$; and at $1415,1,065 \mathrm{~m}$. The average rate of migration during this time was $2.7 \mathrm{~m} / \mathrm{min}$ and the maximum about 4 $\mathrm{m} / \mathrm{min}$. The zone of cracking reached its westernmost point, the Ainahou Road, by 1000 April 10 (pl. $3 J$ ).

The cracks continued to widen after they first formed. For example, the hairline crack that opened at 0935 grew to a width of $20 \mathrm{~cm}$ by $1013,46 \mathrm{~cm}$ by $1136,61 \mathrm{~cm}$ by 1253 , and $91 \mathrm{~cm}$ by 1017 April 10. This widening was caused by actual dilation, not by collapse of the walls of the crack. Collapse did take place subsequently, however, and as a result the crack was $135 \mathrm{~cm}$ wide three months later. Some cracks showed small vertical offsets, most commonly downward to the south.

Surprisingly, we felt no ground movement while standing in the zone of active cracking. However, portable seismometers set up within the zone detected hundreds of microearthquakes, typically occuring in short bursts at intervals of 5-10 minutes.
Meanwhile, the fissure in and above the east rim of Aloi Crater continued to erupt lava at a rate of about $0.1 \times 10^{6} \mathrm{~m}^{3} / \mathrm{hr}$ until midnight. The vents in the crater then apparently stopped erupting, and lava drained back into them. By 0830 April 10, the lake had lowered $9 \mathrm{~m}$, although the cascade of lava from the easternmost vents continued. Inflow and drainage nearly balanced each other for the next 4 days. Discharge from the fissure east of the crater increased during the afternoon of April 14. By 2200, flows or spatter issued from 10 vents along the fissure, the farthest $250 \mathrm{~m}$ east of the rim. Lava in the rising lake began to spill over the crater rim at 0015; the resulting flow had advanced only $1 \mathrm{~km}$ southward by noon, when the eruption rate decreased and the lake surface lowered to 10 $\mathrm{m}$ below the rim.

No visible activity occurred on April 16, but on the afternoon of April 17, lava began to trickle into the crater from the easternmost vent. A small perched lake impounded by its own levees began forming on the crust of the crater fill. Periodically the inflow rate increased, and the perched lake overflowed, a process 


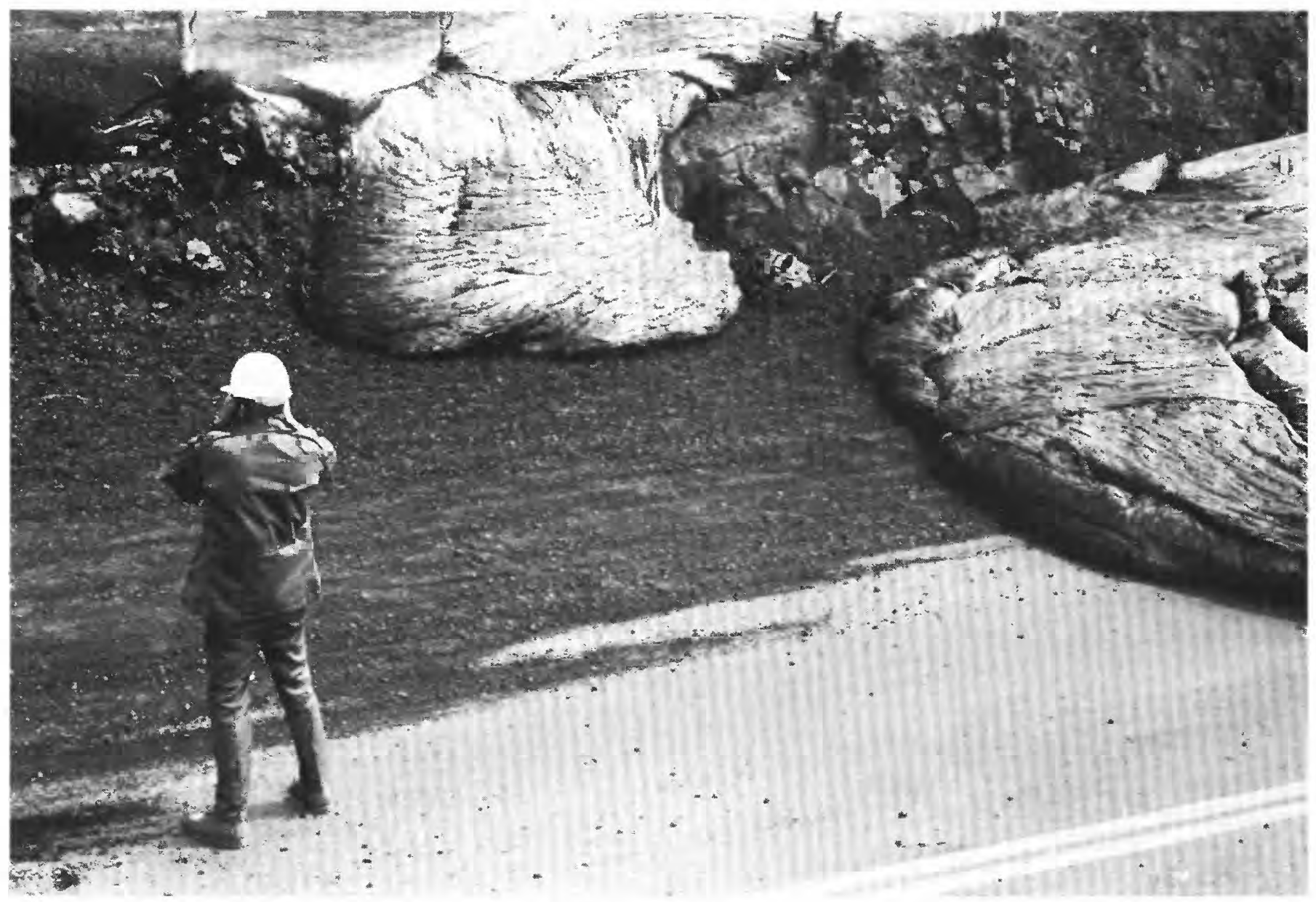

FIGURE 37.-Lava flow spilling over rim of Aloi Crater, 1030 April 9, 1970. Flow crosses deposits of pumice and spatter erupted on December 30, 1969 and scraped off road by highway crew.

that helped build still higher levees above the crater fill. Such activity continued throughout April 18, and the surface level of the perched lake reached an elevation $6 \mathrm{~m}$ higher than the low point on the crater rim. The perched lake began to drain, presumably by leaking through its floor into buried vents, on April 19. The lake and surrounding levee had subsided several meters by the next day, and visible inflow ceased on April 21.

Lava resumed gushing into Aloi on the morning of April 24, and by 1600 the crater was filled and overflowing along its southwest lip. A spatter cone $10 \mathrm{~m}$ high grew rapidly along the fissure near the margin of the lake. Soon the inflow rate lessened, and lake level dropped several meters. Until April 29, inflow was at a low rate, and another perched lake was formed, nestled against the east crater wall adjacent to the fissure. Self-constructed levees confined the small pond on the north, west, and south. Inflow stopped for the last time late on April 29, and by the next day the surface of the perched lake had lowered $6 \mathrm{~m}$, where it stabilized.
Meanwhile, the summit vent of Mauna Ulu remained active. Rising lava broke the roof on the fissure and spilled out in a small flow between the evening of April 8 and 0830 April 9, when fountaining began in Aloi. Thereafter, strong fuming and sporadic bursts of spatter generated during drainbacks characterized the activity. Two brief but spectacular episodes of overflow and dome fountaining $30 \mathrm{~m}$ or more high enlivened the afternoon of April 10, but otherwise the lava lake rose, fell, and circulated quietly, generally toward the west.

Dome fountaining again occurred on April 26. Thereafter, a thin roof was built over the fissure when lava rose to the surface, hovered there for tens of minutes while lava cooled and accreted to the fissure walls, and then withdrew slowly without vigorous degassing. Gradually the roof thickened as the process repeated itself, and spatter that erupted during drainbacks at some depth plastered itself to the underside of the roof. The roof was thick enough to walk on by April 29, although it was rather disconcerting to feel the thudding of spatter beneath one's feet during per- 
iods of drainback. The spatter cones at both ends of the fissure grew several meters; the eastern cone was highest, about $7 \mathrm{~m}$ above the roof, and had a gaping hole in its side (fig. 38). A hole pierced the roof between the two cones on April 28, and another on April 29. These holes formed by collapse and provided vents for the lava column; spatter and small flows were occasionally erupted through them, building cones $2-3 \mathrm{~m}$ high (fig. 38). The largest overflows took place on April 30 from the westernmost new hole, but thin flows reached only a short distance toward Aloi. No further overflows took place during the first half of May.

The activity during the last three weeks in April is interesting for several reasons. The Mauna Ulu vent continued its normal behavior during the time that the new fissure system in and near Aloi was active. The new fissures are not part of the May 24, 1969 system that gave rise to Mauna Ulu but instead are located some $200 \mathrm{~m}$ south. The trend of the fissure segment east of Aloi (pl. $3 J$ ), about N. $48^{\circ}$ E., differs markedly from the typical trend of N. $60-70^{\circ} \mathrm{E}$. for this part of the east rift zone. This segment cuts the southwest flank of Mauna Ulu and projects back to the west end of the Mauna Ulu vent area, as if it were a radial fissure related directly to the shield edifice. At no time, however, did we observe any coordinated relation between activity at Mauna Ulu and along the fissure, although the circulation in the Mauna Ulu lake was dominantly westward, toward Aloi.

Two tests of possible interconnection between Mauna Ulu and the new fissure system were made. One involved chemical analysis of the April 8-9 flow from Mauna Ulu and the first products of the April 9 outbreak in Aloi. The results (Wright and others, 1975, samples DAS70-1213-25 and 26) show that the compositions are olivine-controlled and identical to each other within analytical precision but different from preceding Mauna Ulu compositions. Thus it appears that a batch of new magma entered both the

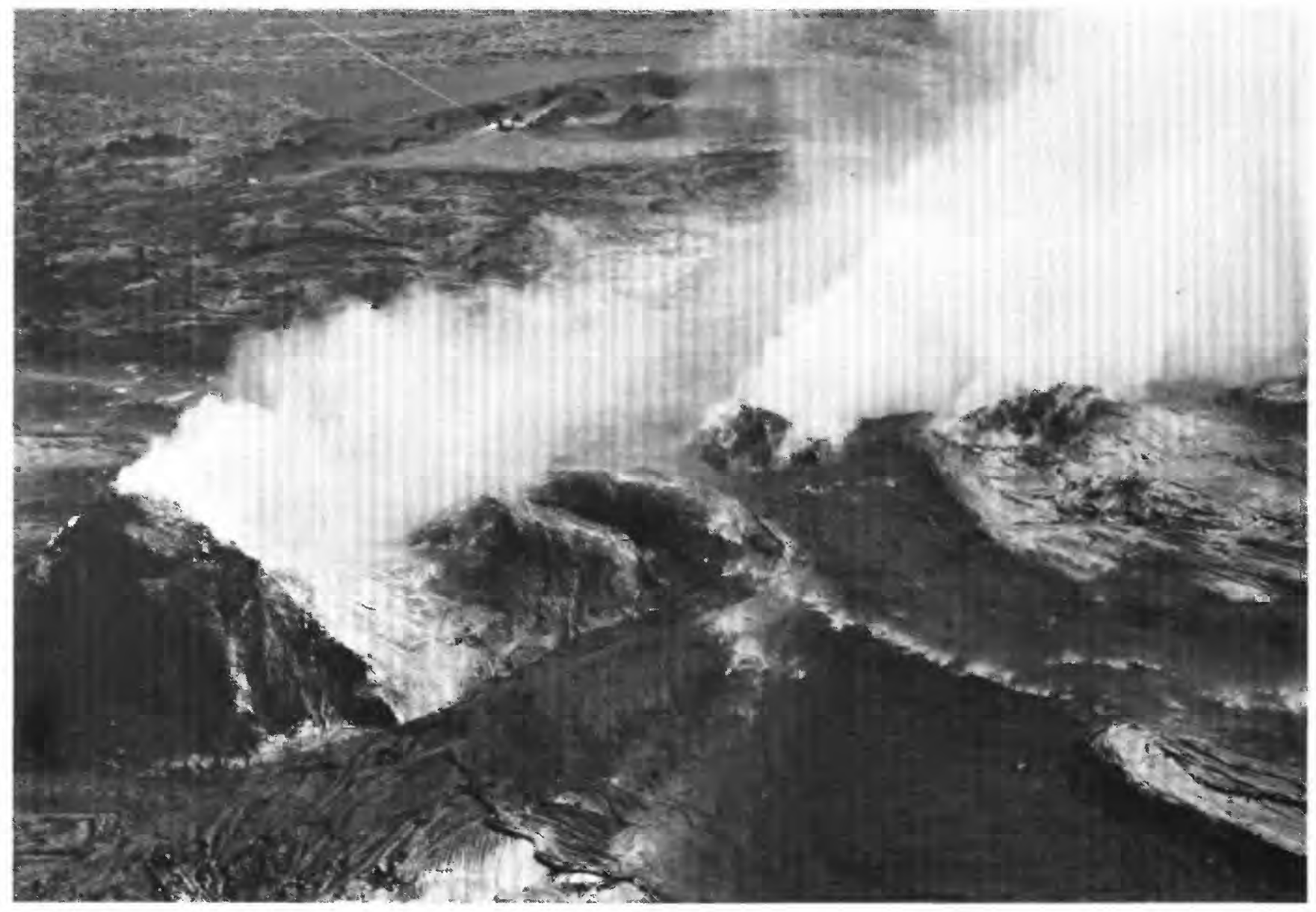

FigURE 38.-Aerial view looking southwest over Mauna Ulu vent area, May 9, 1970. Fissure is mostly roofed, but four cones (westernmost obscured by fume) indicate its location. Fume issues from large hole in west side of easternmost cone, which is about $7 \mathrm{~m}$ high. Note fresh (relatively dark) flow erupted from low, heavily fuming cone on April 30. Remains of tephra mound formed in 1969 are in center background. 
Mauna Ulu and Aloi plumbing systems just before the outbreak, implying that the systems were interconnected at some unknown depth.

The second test used a chemical tracer in an unsuccessful attempt to determine if a direct, shallow connection existed between the Mauna Ulu vent and the new fissures. About $455 \mathrm{~kg}$ of bastnaesite ( $(\mathrm{Ce}$, La) $\mathrm{CO}_{3} \mathrm{~F}$ ) was thrown into the Mauna Ulu lake, and samples of erupting lava were taken at intervals of 20 minutes for the next five hours from the fissure segment east of Aloi and on several successive days from both the new fissure and the Mauna Ulu lake. Neutron-activation analysis for lanthanum by L. P. Greenland shows no detectable increase in any of the samples, including those from the Mauna Ulu vent, suggesting that the bastnaesite was either flushed quickly out of the system or diluted to an undetectable concentration.

\section{MAY 15-JULY 5, 1970}

A swarm of earthquakes on May 15-18 (pl. 2B, C;
Endo, 1971) occurred along Kilauea's east rift zone between Mauna Ulu and the summit caldera. Considerable ground deformation accompanied the earthquakes. Duffield, Jackson, and Swanson (1976) interpreted these events as accompanying shallow intrusion of magma beneath the south part of Kilauea Caldera, near its intersection with the east rift zone. They speculated that structural adjustments resulting from this intrusion reopened the underground conduit system connecting the summit of Kilauea and Mauna Ulu, ending a 4 $1 \frac{1}{2}$ month period in 1970 during which the eruptive activity at Mauna Ulu had waned relative to that in 1969.

Vigorous activity resumed at Mauna Ulu, and weak spattering occurred in Aloi Crater, on May 21, only three days after the earthquake swarm. The Aloi activity lasted only one day, adding a small volume of lava to the crater and forming two driblet spires (fig. 39). The vigorous Mauna Ulu activity continued for more than a month. Hundreds of small, short-lived overflows spilled through new vents in the largely roofed fissure and through the four pre-existing cones

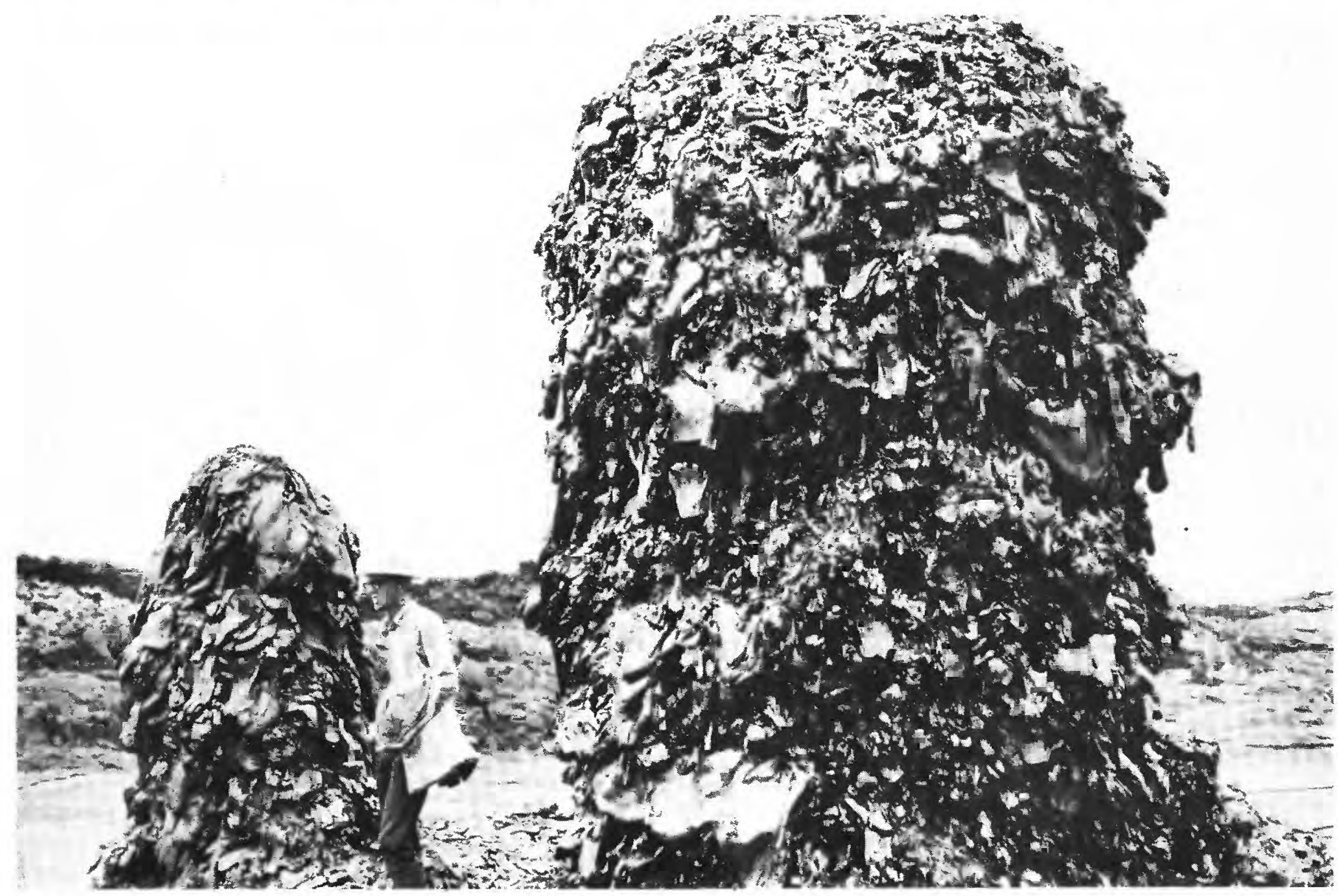

FIGURE 39.-Driblet spires in Aloi Crater formed on May 21, 1970. Whether the spires are hornitos- "rootless vents on the backs of lava flows" (Wentworth and Macdonald, 1953, p. 52) - or cones built over true vents is not known. 
on May 21-23, 26-31, June 5-11, 14-20, and 23-28. Each flow lasted 5-15 minutes, followed by a 10-15minute period of drainback and renewed rise of the lava column. During two typical 7-hour periods on June 5 and 15 , we counted 19 and 30 flows, respectively. The gassy flows formed shelly pahoehoe of both sheet-flood and amoeboid varieties (Swanson, 1973). The volume rate of discharge was small, of the order of $10^{3} \mathrm{~m}^{3} / \mathrm{min}$, and the slope gentle, 1-3 degrees. Consequently flowage was rather slow, generally $0.5-1$ $\mathrm{m} / \mathrm{sec}$, and a plastic crust had time to form on the surface of the moving flows. The flows "stopped moving because the feeding lava column withdrew back down the vent, and the hydrostatic head was then insufficient to rupture the chilled skin on the toes at the leading margin of the flow" (Swanson, 1973, p. 619). Thus, most flows halted as soon as drainback began, after having advanced only a few hundred meters.

Overflows only rarely lasted long enough to advance much beyond the Mauna Ulu edifice itself. We estimate that less than 20 percent of the lava erupted during this period flowed beyond the margins of the shield. Most of these longer flows travelled as rapidly flowing rivers in distinct, narrow channels for hundreds of meters downslope from the vents before spilling out and forming pahoehoe lobes. Many of these flows moved southwestward, eventually covering almost all of the tephra mound built in 1969; other flows entered the Alae area and still others flowed short distances eastward (pl. $3 K$ ).

In late June, a lava tube formed by roofing of a channel carried lava two-thirds of the way down the northwest flank of the shield. Flows and rootless spatter built a low mound at the mouth of the tube, and pahoehoe continued to flow northward toward Puu Huluhulu and westward into the Aloi Crater area until June 29. Lava entered the tube through a hole high in the wall of the roofed fissure. When the lava column rose, the tube was active; when the column fell, the tube became inactive.

The spatter cones, the largest at the east end of the fissure (fig. 40,), grew substantially during spattering accompanying drainback events. Occasional periods of more vigorous fountaining broke up fragile cones, but later, weak spattering largely restored their original shapes.

Virtually all lava erupted from Mauna Ulu between May 22 and 30 was added to the south flank and the summit, largely filling the saddle between the two cones (fig. 41A, profile 2). By noon June 7, however, the north as well as the south flank had been covered (profile 3). Between noon on dune 7 and the morning of June 8, both flanks and the two cones grew substantially higher, and this growth continued through June
20 (profiles 4 and 5). Later in June, flows were added preferentially to the north flank (profile 6).

The low point along the fissure, protected between two cones, remained at nearly the same elevation between May 30 and June 20. Theodolite measurements indicate that this low point increased in height only $3.3 \mathrm{~m}$ between May 31 and June 27, at which time it was $79.9 \mathrm{~m}$ above the base of Mauna Ulu, estimated from the topographic map to be at an elevation of 951 m (3,120 ft), after allowing for a 2-m-thick flow erupted in December 1965 (Fiske and Koyanagi, 1968). The east cone was $94.3 \mathrm{~m}$ above this base on June 20 and 27; it was this height, recomputed as about $100 \mathrm{~m}$ on the basis of an improbable base elevation $(3,100 \mathrm{ft})$ that was given as the height of the shield by Swanson, Jackson, Duffield and Peterson (1971, p. 12).

This period of shield growth was the last for the western half of Mauna Ulu during the eruption, except for a brief period in January and February 1971. Most subsequent flows issued from vents on the east flank of the shield. After June 1970, the height of the summit gradually decreased by collapse of spatter cones and segments of the rim into the ever-widening crater (fig. $41 B$ ). During the 13 -month period of growth from May 1969 to June 1970, the height of the shield increased in a linear fashion if averaged over periods of several weeks (fig. 6). Over shorter intervals, however, the rate of growth was decidedly episodic (figs. 6 and $41 A$ ).

\section{THIRD STAGE OF ERUPTION JULY 6-31, 1970}

Early on July 6, a swarm of small earthquakes, mostly recorded only by instruments near Mauna Ulu (pl. $2 C$ ), accompanied the opening of a $250-\mathrm{m}$-long fissure between 400 and $650 \mathrm{~m}$ downrift from the summit of Mauna Ulu (pl. 4A). This event is taken as the beginning of the third stage of the eruption. A row of spatter cones was quickly built by low fountains along the fissure, and flows advanced southward to the site of Alae Crater and downrift to a point north of Kane Nui o Hamo (pl. 3). On July 8, activity became centralized at three vents along the new fissure, where dome fountains $15-20 \mathrm{~m}$ high played through July 9 . The western two vents erupted much lava in August and are designated from east to west vent 1 and vent 2 , respectively (pl. $4 A$ ). Lava erupted during this time differs in chemical composition from that produced earlier, as chemical variant 5 (Wright and others, 1975) of the eruption first appeared. Dome fountaining and somewhat more gassy fountaining occurred from the three vents on July 13-15, 16-17, and 20-21, and flows again moved south and east-northeast. Many small lava tubes formed at this time by crusting over narrow channels. 


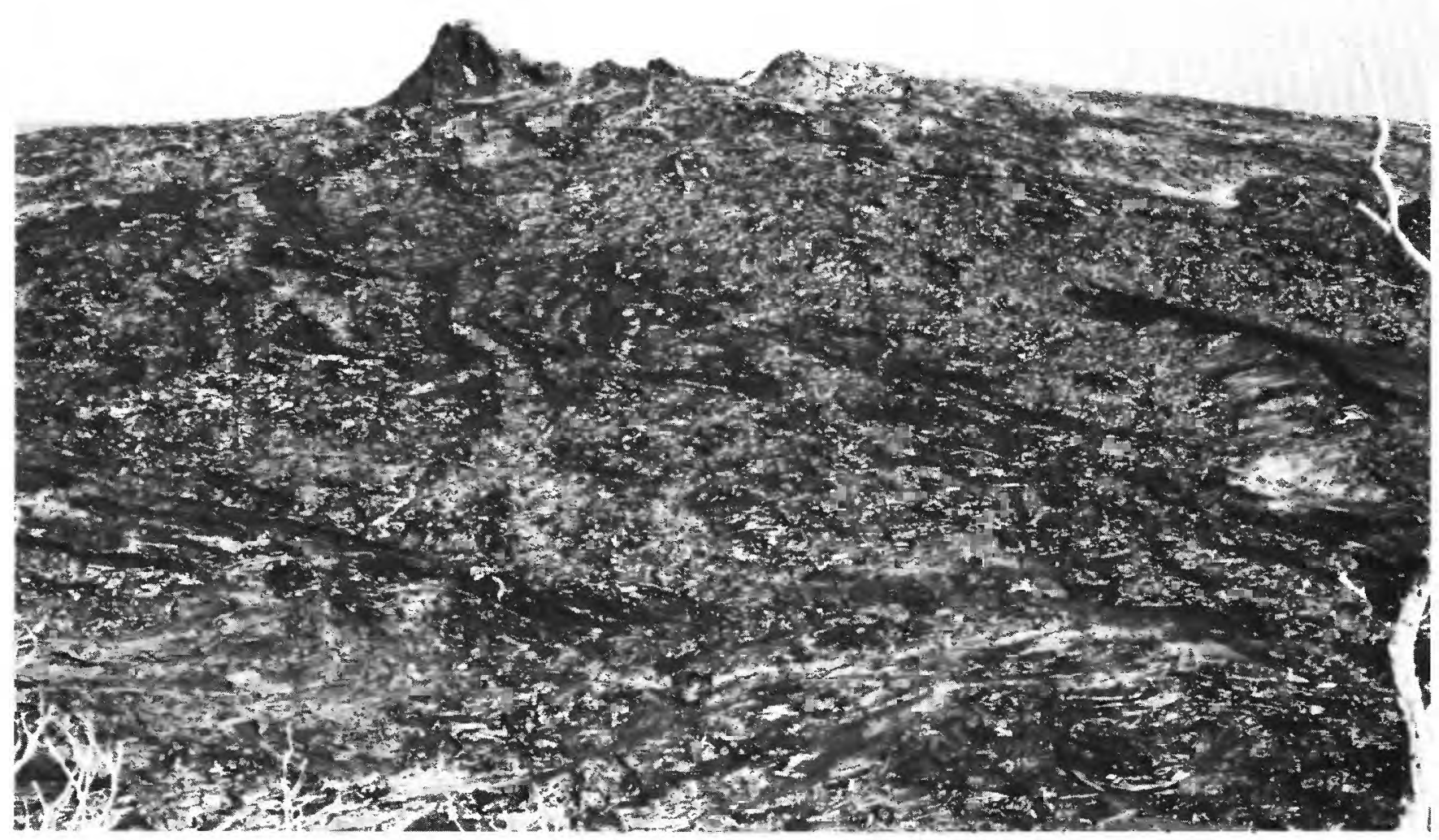

FIGURE 40.- Mauna Ulu shield during a lull in activity on June 20, 1970. View from top of Puu Huluhulu. Compare figure $30 A$, taken from nearly the same location. Note shieldlike form of flanks, composed of hundreds of narrow pahoehoe streams. East cone is
$15 \mathrm{~m}$ higher than low point at summit just east (left) of west cone. Low mound of flows and rootless spatter at mouth of lava tube mentioned in text is along right edge. $\mathrm{N}$

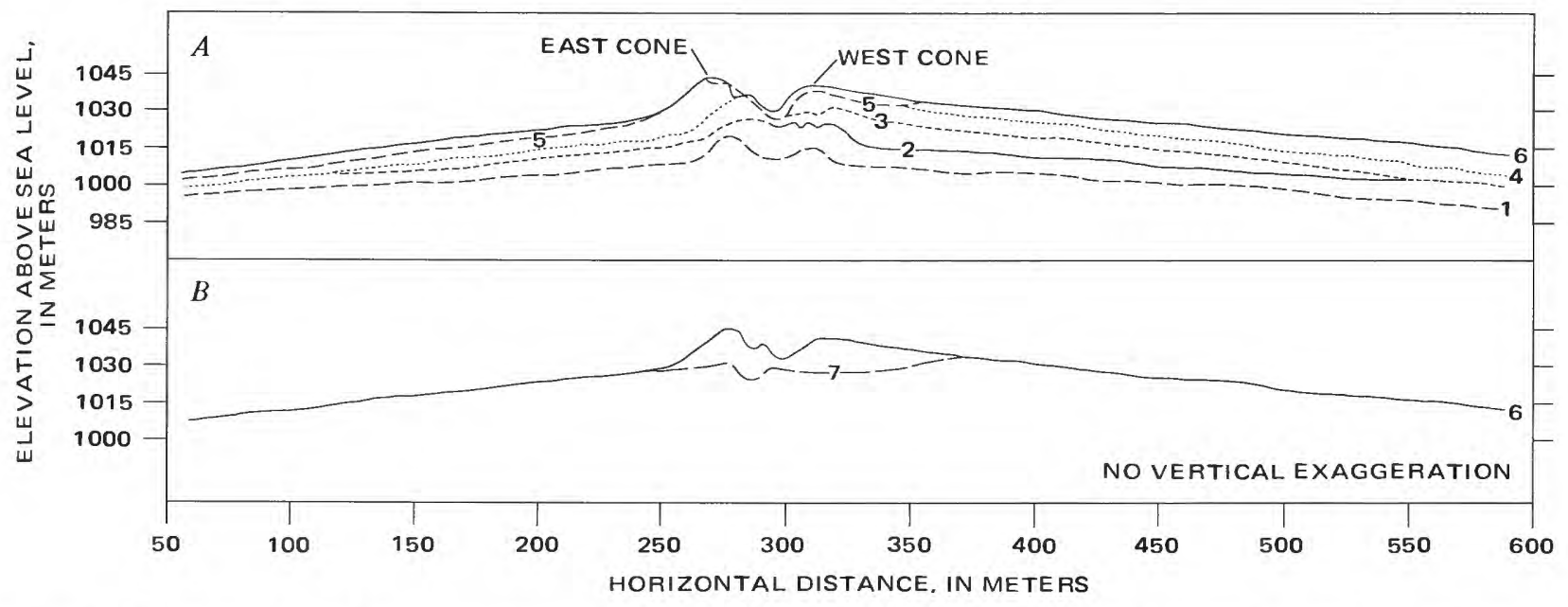

FiguRE 41.-Profiles of Mauna Ulu as seen from parking lot at west end of Pauahi Crater (pls. 1 and $3 K$ ) during and after period of rapid growth in May and June 1970. A, Profiles during period of growth: 1, May 22; 2, May 30; 3, June 7; 4, June $10 ; 5$, June $20 ; 6$, July 2, 1970. $B$, Profiles after period of growth: 6, same as in $A ; 7$, mid-June 1971. Note lower eleva- tion of summit area in 1971, caused principally by collapse of material into the enlarging summit crater. Profiles 1-6 traced from photographs taken with an exactly positioned camera by $\mathbf{H}$. A. Powers. Profile 7 traced from photograph taken with a different camera no more than $3 \mathrm{~m}$ from Power's site. Scales are approximate. 
The roof over the summit vent of Mauna Ulu foundered during the early part of this activity, possibly triggered by ground motion during either opening of the new fissure or during later strong fountaining activity. An elongate crater $25 \mathrm{~m}$ wide by $120 \mathrm{~m}$ long with treacherous overhanging walls was developed by the repeated collapse, but the prominent east cone and much of the west cone were not destroyed. The lava column remained $25-40 \mathrm{~m}$ below the surface, visibly unaffected by fountaining a short distance downrift. Lava in the pool constantly circulated, generally emerging quietly at the west end of the crater, moving slowly eastward, and plunging downward at the east end accompanied by degassing and low fountaining. Occasionally the circulation pattern reversed, but at no time did the lava column rise high enough to overflow.

The east flank of Mauna Ulu began to emit copious amounts of fume, especially after rains, a few days after the summit roof foundered. The fume issued from a narrow zone extending from the east cone halfway to vent 2 , along the trace of the Mauna Ulu fissure (pl. 4A). Over the next 6 months, this zone, last active on August 22, 1969, became important to the development of Mauna Ulu, and it was here that a large collapse trench eventually formed.

\section{AUGUST 1-OCTOBER 27, 1970}

After 12 days without surface activity, a nearly circular hole, designated vent 3 , opened during the night of August 2-3 high on the east flank of Mauna Ulu, only $150 \mathrm{~m}$ from the east cone along the zone of fume emission (pl. 4B). This hole was at the site of the old eastern vent area, inactive since July 15,1969 . The 3-5 m hole pierced the thin roof of a much wider chamber, within which lava was observed in constant turmoil, vigorously spattering at depths of $30 \mathrm{~m}$ or more. As the month progressed, lava rose to the surface of vent 3 and spilled out several times, although only two of these overflows, on August 8 and 16, were observed in motion. The flows extended north, south, and east in narrow streams no longer than $800 \mathrm{~m}$. More vigorous periods of spattering accompanying rapid drainback built a low cone around the hole. We were seldom able to approach the hole closely, because of the instability of the thin roof and the overwhelming heat. On the rare occasions when observation was possible, we saw either no circulation pattern in the lava column or at most a very slow west-to-east movement, and we detected no obvious coordination between the nature of activity in this vent and that at the summit or vents farther downrift. At least once, violent emission of gas explosively destroyed the cone, littering the ground surface with debris for tens of meters around the vent.
Vent 1 reopened sometime between August 4 and the morning of August 7, probably on August 6, as suggested by slight detumescence of Kilauea's summit (pl. 2A). As Swanson and Peterson (1972, p. 4) described, "Lava quietly welled out of this vent, flowed in a surface river for $50-100 \mathrm{~m}$, and then disappeared into a tube [pl. $4 B$ ] which carried the lava for several tens of meters before feeding it beneath the crust into the molten part of the lava lake in Alae Crater." Concurrently, vent 2 resumed activity, sending small flows part way across the crust of the Alae lake. Vent 2 continued to erupt surface flows until midday on August 8 , the same day that vent 3 briefly emitted two narrow flows, one eastward, the other southward. Greeley (1971, fig. 2) shows maps illustrating this activity at five times between August 7 and 11 .

Meanwhile, lava began draining out of the molten lake within Alae Crater through the lava tube last active in late October 1969 and now buried $21-22 \mathrm{~m}$ beneath new lava (pl. 4B; Swanson and Peterson, 1972). Lava issued from the mouth of this tube $2.5 \mathrm{~km}$ south of Alae and formed a flow that was first discovered at 0830 August 11, when it was within $100 \mathrm{~m}$ of the Chain of Craters Road $4.5 \mathrm{~km}$ downslope from Alae. We do not know when the draining began but suspect it was late on August 7 or early on August 8, when the crust on the lake began to subside. The crust had nearly completed its $13-\mathrm{m}$ subsidence by 1030 August 11, at which time the rate of outflow had dropped from $3.4 \times$ $10^{4} \mathrm{~m}^{3} / \mathrm{hr}$ to $1.3 \times 10^{4} \mathrm{~m}^{3} / \mathrm{hr}$, a rate that just balanced inflow. For the next 12 days, lava continued to pour at this reduced rate into the Alae lake from vent $l$ and leave the lake through the exit tube. On August 23, vent 1 ceased erupting but vent 2 began feeding lava at about the same rate through another inlet tube (pl. $4 C$ and fig. 42 ) into the molten lake in the crater. Lava continued to leave the lake through the same exit tube, and the remarkable balance between inflow and outflow was maintained. Observations through skylights in the roofs of lava tubes (Peterson and Swanson, 1974, pl. 52 and 53; Swanson, 1973, fig. 9) confirmed the role that tubes played in carrying lava into and out of Alae, which served as a holding reservoir along the route of flow from the vents to the seacoast (Swanson and Peterson, 1972).

The development of the complex pahoehoe and aa flow that formed from the Alae outflow was described by Swanson (1973) and Peterson and Swanson (1974). Quoting from Swanson (1973, p. 621),

***Lava that first emptied from [the exit tube] onto the ground surface ${ }^{* * *}$ changed to aa after a few hundred meters of surface flowage. Gradually, however, the pahoehoe tube system extended itself, in part by a continuing flow of lava through interconnecting pahoehoe toes and in part by crusting over of small surface channels. The formation of the crust slowed cooling, so that hot, rela- 


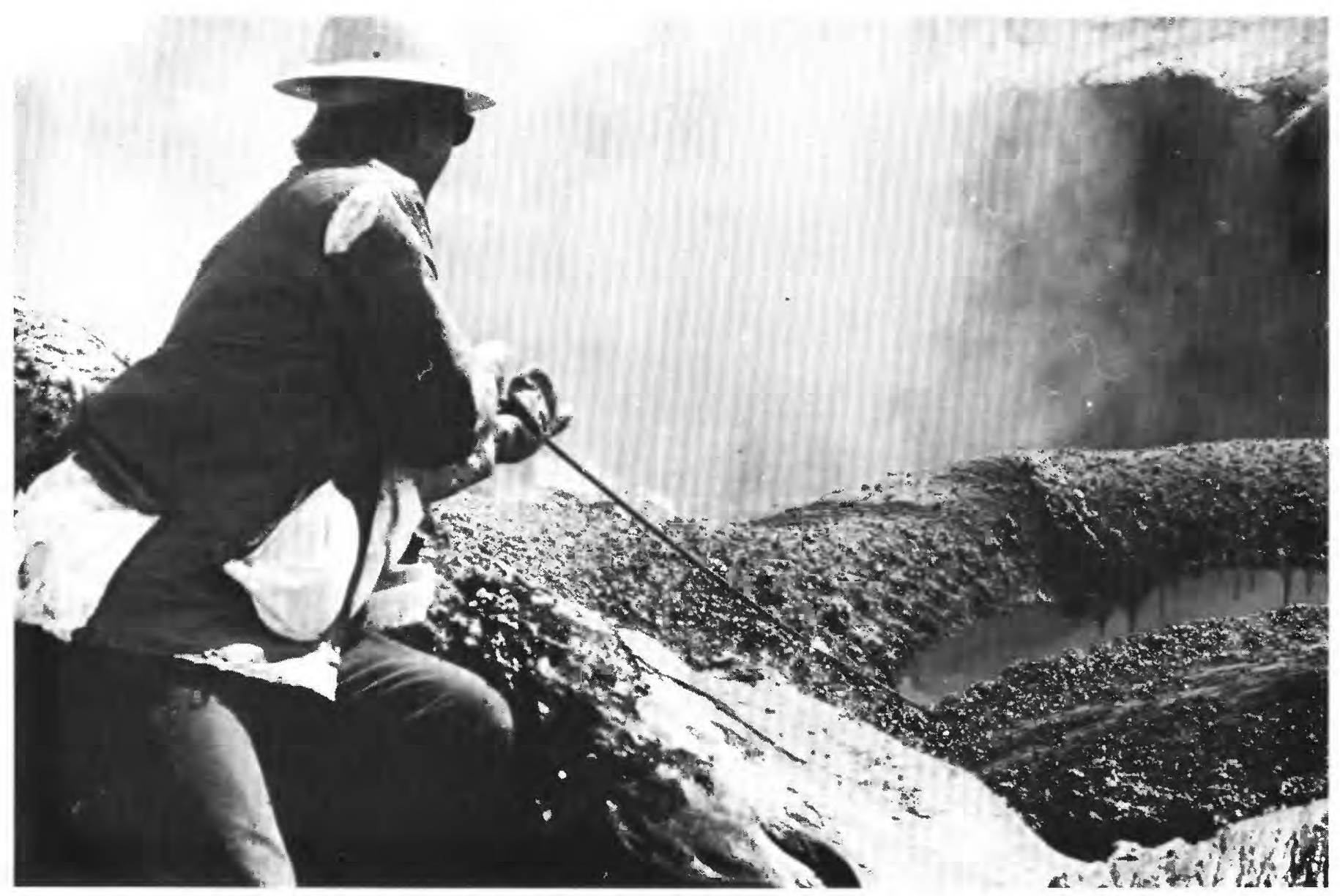

FIGURE 42.-Skylight in tube between vent 2 and Alae in September 1970 provided good opportunity to sample lava with small dipper attached to stainless steel rod. Results were poor, because the relatively high flow rate and tensile strength of the lava made it difficult to submerge the clumsy, relatively light probe. Better penetration was obtained by hurling a heavy steel bucket, tethered by a stainless steel cord, with as much force as possible into the lava. tively fluid pahoehoe encroached on and eventually covered the slightly older aa flows. As each pahoehoe lobe broke onto the surface from the end of the new tube and advanced downslope, it changed gradually to aa that was covered shortly afterward by still newer pahoehoe that emerged at the surface from the ever-lengthening tube system. This process-pahoehoe changing to aa only to be covered by slightly younger pahoehoe as the tube system advanced - was repeated over and over again ***

By the evening of August 13, the flow was descending Poliokeawe Pali, and early on August 15, it began to pour over Holei Pali. Meanwhile, the east side of the flow covered an 800-m segment of the Chain of Craters Road above Poliokeawe Pali (fig. 43) and started a major fire in the tinder-dry forest. On August 17, lava began to pool in a broad flat area at the base of Kealakomo Pali, $2 \mathrm{~km}$ south of Holei Pali (pl. $3 K$ ). Large tumuli (Swanson, 1973, fig. 10), flattopped uplifts, and sag structures commonly formed on the surface of the pooled lava, which was fed by a complex system of anastomosing distributary tubes. The pooled flow slowly moved seaward from the base of Kealakomo Pali, a month later trickling into tide pools on September 21. The rate of flow into the sea later increased, and the new front eventually became more than $650 \mathrm{~m}$ wide (pl. $3 \mathrm{~K}$ ). The flow constructed a small lava delta that extends about $10 \mathrm{~m}$ from the old shoreline, has an area of about $1.4 \times 10^{4} \mathrm{~m}^{2}$, and a volume of about $0.6 \times 10^{6} \mathrm{~m}^{3}$ (Peterson, 1976).

No movement of lava over the cliffs south of Alae was seen between September 27 and 30, although lava continued to enter and leave the crater through the inlet and outlet tubes. Apparently the tube system was blocked somewhere below Alae, although no uplift of the floor of the crater was noted, an expected consequence if the tube system were closed. On October 1 , voluminous flows broke out from the system 2 $\mathrm{km}$ south of Makaopuhi Crater, inundating more forest and roadway. A lava-tube system began to form, and the flow gradually advanced over the palis in a series of surges of pahoehoe and aa. The older tube system was not reactivated. Lava continued flowing 


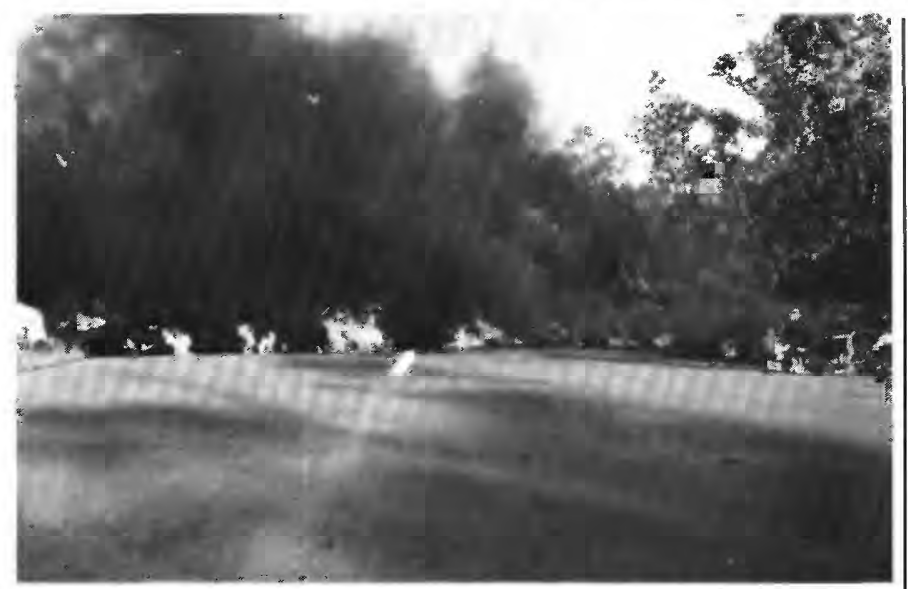

Figure 43.-Asphalt burns as pahoehoe flow crosses Chain of Craters Road above Poliokeawe Pali, August 15, 1970. This flow started a large fire in the ohia and kukui forest, threatening rare native Hawaiian plants and trees before being brought under control. Photograph by J. B. Judd.

through the new system until October 26, stopping just short of the coast when inflow to Alae temporarily ended.

Throughout this entire period, a slowly circulating, rising and falling, and periodically degassing lava lake occupied the summit crater of Mauna Ulu. The activity was similar to that of the preceding month, with the lava generally $15-20 \mathrm{~m}$ and occasionally $30 \mathrm{~m}$ below the rim. The dominant direction of circulation continued to be west to east, with nearly constant low fountaining at the east end. The crater was periodically widened by rockfalls from its walls.

Vent 4 (pl. $4 D$ ), initially a tiny spatter cone, opened on September 23 or 24 . Within a week, a small collapse crater $2 \mathrm{~m}$ across formed at the east base of the cone; the crater was roofed over a few days later. When viewing conditions were favorable, lava could be seen at a depth of $20-30 \mathrm{~m}$ within vents 1 to 4 moving eastward though underground passageways. Each vent overflowed several times, sending lava northward toward the edge of the lava field and southwestward, sometimes reaching as far as the Alae subsidence bowl, where the flows constructed a "lava fan" extending to the floor of the bowl (Swanson and Peterson, 1972).

The four vents increased activity in early October, each of them going through several episodes of violent degassing with minor spattering, quiet lava flows, and fountaining. Small spatter cones were constructed at all the vents, with three cones clustered at vent 2 (pl. $4 D$ ). On October 26, the cone at vent 4 caved in, forming a small hole that within a day enlarged by collapse to a pit $18 \times 13 \mathrm{~m}$ in diameter. Continued collapse eventually made the crater nearly circular (pl. $4 D$ ).
Also on October 26, all flow in the inlet tube between vent 2 and Alae Crater stopped, and lava was visible only in vent 4 and the summit crater. Accompanying this decline was an increase in tilt and seismic activity in Kilauea Caldera (pl. 2), as if pressure were building behind some constriction in the magma conduit system connecting the summit reservoir and Mauna Ulu.

\section{OCTOBER 28-NOVEMBER 18, 1970}

Pressure was relieved on October 28, when many overflows poured from vents 1,2 , and 4 . Seismic activity at the summit of Kilauea sharply declined and summit swelling stopped at the same time. The flows advanced north and northeast in open channels that quickly roofed over to form tubes (Cruikshank and Wood, 1972, fig. 9).

The cyclic activity at vent 4 was especially interesting during this period. A cycle began as the level of lava gradually rose $10-15 \mathrm{~m}$ to the brim of the crater, then overflowed for periods of several minutes to several hours. Finally, a low fountain broke the crust on the overflowing pool and quickly grew in volume and vigor to a height of 10-15 m, accompanied by a sudden drop in the level of lava and cessation of overflow. The fountains stopped as the lava withdrew, crusted over, and began its slow rise once more. The gas-piston activity first observed at the summit vent was clearly in operation. All the while we recognized no effect of activity at vent 4 on other vents, where lava continued to issue at a relatively uniform rate or maintained its own slow rise-fall cycles.

Vent 1, inactive for several days, collapsed on November 5 , forming a crater $15 \mathrm{~m}$ in diameter and 15-20 m deep (pl. 4E). When discovered, the new crater contained no lava, although the walls were red hot in places. Lava had returned to the crater by the next morning and took part in many episodes of overflow and drainback during the next week. Then the lava stagnated and solidified at a high level in the crater, ending activity at vent 1 until February 1971.

At 1430 November 13, a loud boom and a rising cloud of fume and dust issued from the east flank of Mauna Ulu. Rushing from the Alae area, Peterson and Swanson found a new collapse crater still forming 75 m east of vent 4 . This crater, designated vent 5 (pl. $4 F$ ), quickly reached $30 \mathrm{~m}$ in diameter (Cruikshank and Wood, 1972, fig. 25). The crater at vent 4 enlarged to $25 \mathrm{~m}$ by $40 \mathrm{~m}$, perhaps enhanced by ground motion caused by the opening of vent 5 . During the ensuing five days, the two craters participated together in the cycle of slowing rising lava, overflow, and fountaining with drainback. Vent 5 , the rim of which was about $10 \mathrm{~m}$ lower than that of vent 4, began overflowing several minutes sooner, but otherwise the two craters acted in unison, implying a connection between them. 
Drainback episodes at vents 4 and 5 were often followed within a few tens of seconds by especially violent degassing from the cone at vent 3 , upslope from the two craters. This evidence suggests that the main source of lava in vents 4 and 5 was located beneath vent 3 , the site of the eastern vent area so active during the first two months of the eruption. A loud roar lasting a few seconds to several minutes accompanied the degassing at vent 3 , and small bursts of spatter were sometimes thrown to heights of $60 \mathrm{~m}$.

During this time, the overflows from vents 4,5 , and occasionally 2 spread $3 \mathrm{~km}$ downrift and repeatedly poured into Alae Crater, adding to the lava fan and completely covering the floor of the recently surveyed depression (pl. $3 L$; Swanson and Peterson, 1972). Overflows stopped on November 18, and lava pools in the vents remained about $10 \mathrm{~m}$ below the rim.

Meanwhile, lava resumed coursing through the Alae inlet and outlet tubes on November 2 (fig 44). Thin streams of pahoehoe, which fed through the tube system, reached the base of Holei Pali several days later. The rate of inflow to the crater increased on November 14, and a new skylight revealed a bilevel tube with 8-m lava falls carrying lava into Alae (Cruikshank and Wood, 1972, fig. 11). On November 15, surface flows broke out $3.5 \mathrm{~km}$ south of Makaopuhi Crater; they soon covered several hundred meters of the highway and advanced toward a grove of rare native Hawaiian vegetation in Naulu Forest (pl. $3 L$ ). National Park Service personnel bulldozed up part of the pavement and used it, together with rock scrapings, to construct low dams that successfully diverted the thin, slowly moving pahoehoe flow off the road and over the cliffs, thereby saving the forest.

The floor of Alae Crater subsided during the night of November $12-13$ as much as $3 \mathrm{~m}$ near the exit tube. Swanson and Peterson (1972) interpreted this to indicate deepening of the exit tube by the removal of a partial blockage.

\section{NOVEMBER 19-DECEMBER 24, 1970}

Flows continued over Holei Pali until November 25, then at a decreasing rate until November 29, when visible activity stopped. However, lava was observed in both the inlet and outlet tubes of Alae for the next few days, though flowing at a slower speed than previously.

A large new collapse depression formed on the east flank of Mauna Ulu during the night of November 2829 (pl. 4G). The collapse enlarged vent 5 and extended $100 \mathrm{~m}$ downrift, engulfing two cones built at the west end of vent 2 . A pool of lava covered the western third of the floor of the depression to within $15 \mathrm{~m}$ of the rim; the rest of the floor was a jumble of fallen rock from

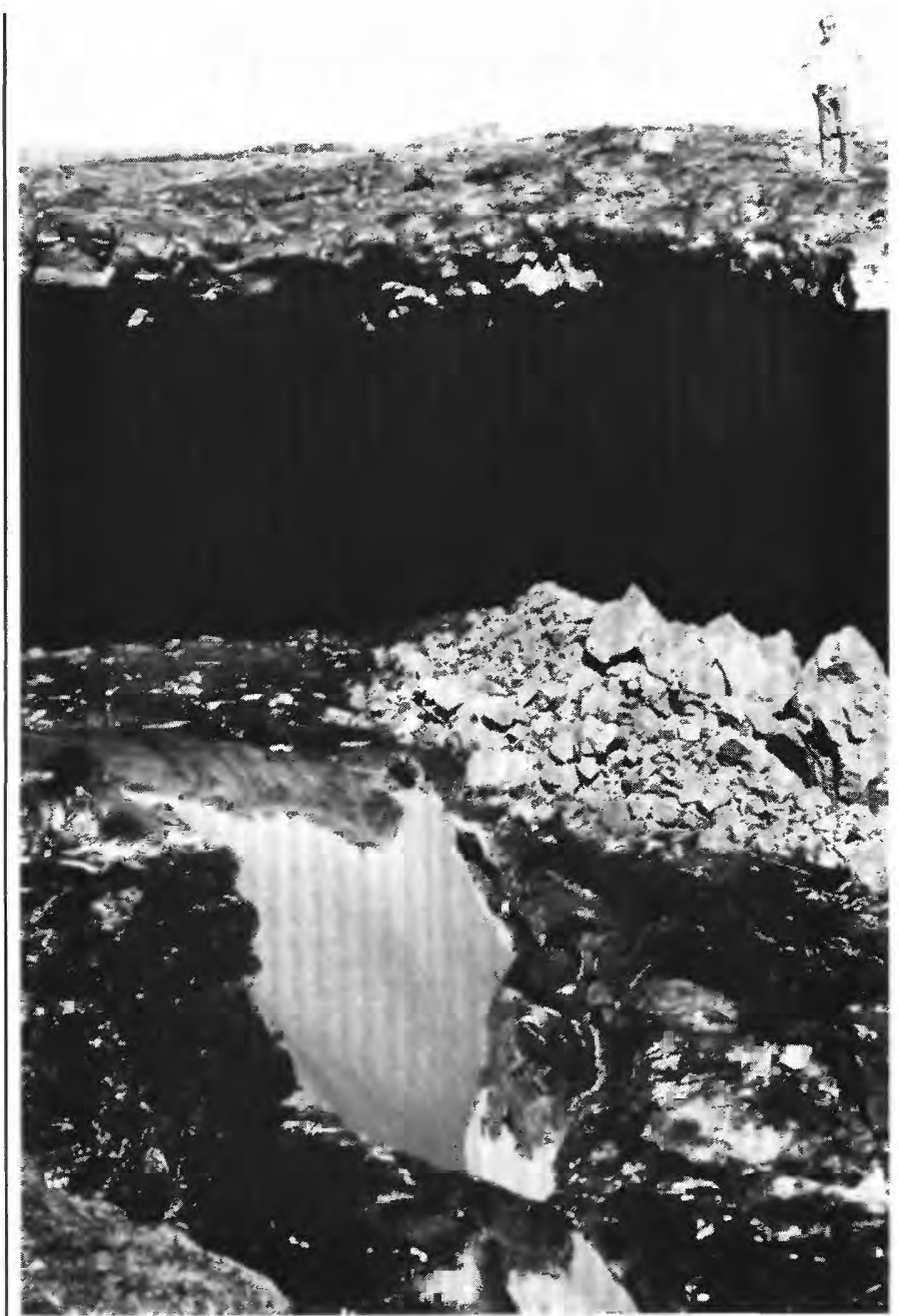

FIGURE 44.-Skylight in outlet tube $100 \mathrm{~m}$ southeast of Alae Crater, November 5, 1970. Lava pours over falls developed on collapsed part of roof of tube. Note recently fallen rubble below man.

the roof and walls. This area enlarged during the next few days to maximum dimensions of $150 \mathrm{~m}$ by $35 \mathrm{~m}$, with a depth of $25-30 \mathrm{~m}$.

The north rim of the summit crater of Mauna Ulu receded at the same time that the collapse depression formed, and the crater now measured about $130 \mathrm{~m} \times$ $80 \mathrm{~m}$ (pl. $4 G$ ). The circulating lava lake continued its activity as before.

On December 2, a rapidly moving stream of lava issued from the west end of the collapse area, filled the trench to the brim, and entered a tube at the east end of the depression (pl. $4 G$ ). This tube is probably the one that had connected vent 2 and Alae Crater before the collapse area captured it. A wide skylight pierced the roof of the tube $30 \mathrm{~m}$ farther east, and lava could be seen plunging over an underground ledge, rounding a broad curve, and disappearing in the direction of Alae. A similarly vigorous flow was observed through 
skylights in the Alae exit tube. By December 3, the flow had slackened and crust had formed on it, but lava continued to enter the tube into Alae. A new flow broke out above Poliokeawe Pali on the afternoon of December 4, covering part of the November 15-29 field. This flow continued until December 8 , when it completely roofed over. No flowing lava was visible again south of Alae until January 2l, 1971.

On December 6, numerous flows that erupted successively from vent 4 spilled into the November 28-29 collapse depression, cascaded over the rough floor, and entered the inlet tube to Alae. Other flows spread northward, and still others advanced onto the floor of Alae. The western two-thirds of the collapse depression was filled with congealed lava by December 8 , when renewed collapse at the site of vent 5 formed a small crater (pl. $4 H$ ) containing a pool of bubbling lava. Strong flow into the tube leading to Alae continued, apparently unaffected by the cyclic gas-piston activity that characterized the pools of lava in vents 4 and 5. By December 13, visible inflow to Alae had stopped, although continued outflow suggested that the lake was supplied through deeper tubes. By this time, overflows and cyclic drainbacks in vents 4 and 5 had ended, and by December 20, the pools of lava had dropped to $20 \mathrm{~m}$ below the surface in vent 4 and $15 \mathrm{~m}$ in vent 5 . On December 20, the sulfur-encrusted cone at vent 3 collapsed into a crater that quickly became $20 \mathrm{~m}$ by $35 \mathrm{~m}$ in diameter (pl. $4 H$ ). A lava pool slowly circulated from west to east $15-20 \mathrm{~m}$ below the rims of vents 3,4 and 5 , suggesting a connection. The rate of flow increased on December 21, but the level of lava dropped to $25-30 \mathrm{~m}$ below the surface. Flow was still vigorous on December 24, but it had stopped when next examined on December 26.

The walls of the craters at vent 3,4 , and 5 gave way on December 21, and large blocks tumbled into the flowing lava and disappeared. Enlargement of the craters continued over the next several days, accelerating as the underground stream lowered and finally vanished beneath the rubble. The most rapid collapse occurred at the east and west sides of the craters, which consequently elongated toward one another.

During this entire period, the lava lake in the summit crater of Mauna Ulu showed little of the varied activity that characterized the vents farther east. From November 19 to December 4, the level fluctuated between $13 \mathrm{~m}$ and $25 \mathrm{~m}$ below the rim, remaining in constant circulation, nearly always west to east. The level rose rapidly to within $6 \mathrm{~m}$ of the rim on December 6 at the same time that vent 4 began frequent overflows. The lake than experienced several gas-piston cycles, with a few bursts of spatter reaching a height of $35 \mathrm{~m}$ during particularly vigorous drain- backs. Lake level dropped on December 7 and remained at depths of 25-35 m for the rest of the period. The crater continued to enlarge by collapse (pl. $4 H$ ), and on December 20, huge blocks peeled away from the northeastern and eastern walls, carrying away the 8-m-high remains of the east summit cone. The crater was about $150 \mathrm{~m}$ long by $85 \mathrm{~m}$ wide on December 24 , (pl. 4I).

\section{DECEMBER 25, 1970-JANUARY 27, 1971}

This period began with a general lull. Harmonic tremor dropped to its lowest intensity in months, and no moving lava was observed until January 14 . Nonetheless, great changes occurred on the east flank of Mauna Ulu.

On January 1, 1971, a narrow bridge separating the enlarged vents 4 and 5 collapsed unseen, and the two craters merged into a trench (pl. $4 I$ ). On January 2, a bridge $60-70 \mathrm{~m}$ long, $30 \mathrm{~m}$ wide, and $10-15 \mathrm{~m}$ thick separated the crater at vent 3 from the trench, and one could look beneath the bridge from one opening to the other. At 1030, the bridge slowly sagged, cracked in the middle, broke along its edges, and finally plunged into and covered the lava $40 \mathrm{~m}$ below. This collapse, closely observed from a point only $50 \mathrm{~m}$ downrift, completed the opening of the trench, which now extended $340 \mathrm{~m}$ between vent 3 and the east end of the November 28-29 collapse depression (pl. 4J). The trench was $25-35 \mathrm{~m}$ wide, $30-40 \mathrm{~m}$ deep, and was floored by a jumble of rubble left from collapse of its roof.

Thick fume issued from the trench for the next 2 weeks, combining with fog generated by evaporation of heavy rains to create very poor viewing conditions. We could sometimes distinguish stagnant, often crusted pools of lava through the dense cloud, and occasionally we heard "sticky' sounds similar to those made by a viscous fluid such as grease moving slowly through a constricted opening. Our impression was that lava was slowly working its way along the trench beneath or through the rubble pile, but no lava was seen in the inlet and outlet tubes to Alae Crater.

Visible activity resumed on the morning of January 14 , and by afternoon the trench was filled by an eastward-flowing river of lava that spilled over the southeast rim and poured onto the floor of the Alae subsidence bowl. No lava was observed in the inlet tube to Alae. Accompanying this renewed activity, the level of lava in the summit crater of Mauna Ulu rose to within $12 \mathrm{~m}$ of the rim, but otherwise its circulation and fountaining pattern remained unchanged. The activity in the trench was again cyclic, with quiet inflow followed by drainback-related fountaining centered at the location of vent 3 , at the west end of the 
trench. This type of activity persisted through January 15 and perhaps longer, but stormy weather prevented observations on January 16-20, when the old inactive cone at vent 2 crumbled away. By January 21 , the trench had drained, and the 10-20-m-deep floor was covered with rubble except for a pool of circulating and periodically degassing lava at the site of vent 3. Lava fed from this pool must have been moving unseen beneath the rubble, for a vigorous stream was pouring through the inlet tube to Alae Crater (pl. $4 K$ ).

Also on January 21, several narrow fingers of pahoehoe emerged from tubes south and southeast of Alae, indicating that lava was again flushing through the Alae holding reservoir. On January 23, small flows fed by the tube system spilled into Makaopuhi Crater (pl. $3 L$ ), the first time that lava had entered the crater since the eruption in February 1969 (Swanson, Jackson, Koyanagi, and Wright, 1976). Flows descended Poliokeawe and Holei Palis the next day (pl. $3 L$ ) and continued through January 27.

\section{JANUARY 28-FEBRUARY 20, 1971}

A new fissure opened west of the summit of Mauna Ulu across the site of Aloi Crater during the evening of January 28 (pl. $4 L$ ). A line of low fountains extended about $700 \mathrm{~m}$ uprift from the lower west flank of Mauna Ulu between the fissures of October 20, 1969 and April 9, 1970. Activity continued until February 10 , building a broad satellitic shield $20 \mathrm{~m}$ high on the west flank of Mauna Ulu and covering an area of 2-3 $\mathrm{km}^{2}$ south of the fissure ( $\mathrm{pl}$. $3 M$ ). Much of the early fountaining was concentrated along the western half of the fissure, but from February 1, the activity was centered on the eastern third, where a lava pond was confined behind natural levees. The pond, located over the northeast part of buried Aloi Crater, overflowed irregularly, and these flows constructed most of the satellitic shield. After each period of overflowing, the pond largely emptied by draining back into the fissure, leaving a flat-floored shelf behind the levees. Such a cycle of filling and emptying occurred several times a day. An irregular depression 2-10 m deep (Cruikshank and Wood, 1972, fig. 5) was left after the pond last drained on February 10.

The lava lake in the summit crater of Mauna Ulu was lower than usual on January 29 and circulated from east to west; it then began rising and was only $3 \mathrm{~m}$ below the rim on February 7-9, the highest level in months. The level dropped when the new fissure stopped fountaining on February 10, and the next day it returned to its normal depth, 15-30 m, which it maintained for the rest of the period. We saw a section of the southwest wall of the crater about $100 \mathrm{~m}$ long by
5-10 m wide fall into the lake on February 18 , producing a splash that reached about $50 \mathrm{~m}$ above the crater rim. This disturbance only briefly interrupted the west-to-east circulation pattern.

The flows south and southeast of Alae Crater declined and stopped less than a day after the fissure west of Mauna Ulu opened. This timing suggested that the input to Alae had ended when the new activity began, and also that a magma conduit system connected the trench and new fissure. As if a valve had been turned, vent 1 (pl. $4 M$ ), inactive since November 10-12, began erupting less than three hours after the vents on the west flank had stopped activity. By the morning of February 11, a vigorous stream of lava was pouring into the subsidence bowl in Alae, which had already begun to overflow. The $9.7 \times 10^{5} \mathrm{~m}^{3}$ depression had filled in less than 20 hours, indicating an eruption rate of at least $4.85 \times 10^{4} \mathrm{~m}^{3} / \mathrm{hr}\left(1.16 \times 10^{6} \mathrm{~m}^{3} /\right.$ day $)$. A rapidly flowing river emerging from a tube at the north edge of Alae (Cruikshank and Wood, 1972, fig. 8 ) was the only observed source of the flow. This tube was apparently the same one that was active in August 1970, when vent 1 was also active (pl. $4 B$ ). Overflows from Alae again entered Makaopuhi Crater and extended $3 \mathrm{~km}$ southward. Lava accretion built the southeast rim of Alae $5 \mathrm{~m}$ higher, to about $29 \mathrm{~m}$ above the preeruption rim (Swanson and Peterson, 1972, fig. $2 E$ ). Vent 1 stopped erupting on February 19, and a spatter cone built since February 10 caved in, forming a crater 8-10 $\mathrm{m}$ in diameter (pl. $4 N$ ).

Throughout this activity, strong fume was emitted from a skylight in the old (west) inlet tube to Alae (pl. $4 M$ ), suggesting active inflow fed by a vent in the trench, probably vent 3 . On February 20, lava was seen through skylights in the outlet tube, but no new tube-fed flows formed downslope from Alae until February 21.

A new area of collapse formed about $1 \mathrm{~km}$ south of Alae Crater during either the fountaining west of Mauna Ulu or the filling and overflowing of Alae. The collapse area (fig. 45 and pl. $4 M$ ), some $200 \mathrm{~m}$ by $800 \mathrm{~m}$ long in a downslope direction, was characterized by jumbled and tilted blocks of surface crust overlying rough, spiny lava that was apparently still liquid, though quite viscous, during the collapse. A rootless aa flow extended a short distance downslope from the lower end of the area. Crust at the upper end of the area was mostly unbroken but sagged $6-8 \mathrm{~m}$; the jumbled area had apparently moved downslope as well as sagged. No connection was evident between this area and any vent at Mauna Ulu. We speculate that overflows from Alae Crater in mid-February formed a pool behind an unstable dam that later failed, allowing downslope flowage of the relatively cool, viscous lava. 


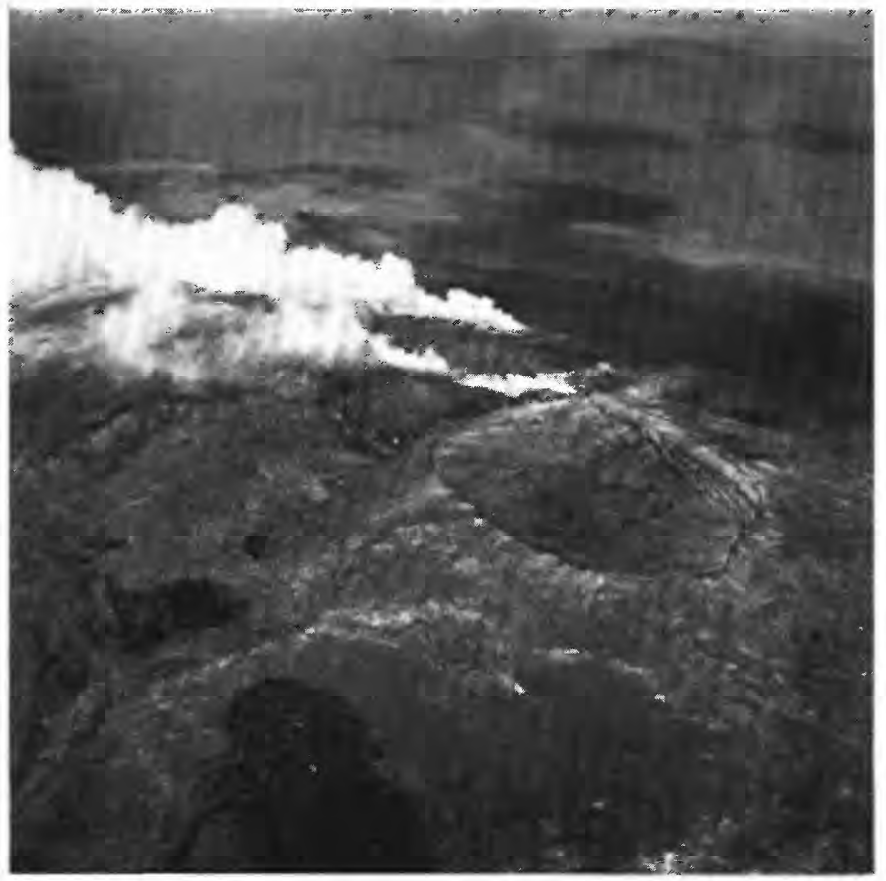

FIGURE 45.-Aerial view looking north over subsidence bowl at Alae Crater on March 28, 1971, showing fume cloud billowing from Mauna Ulu trench and summit crater and smaller cloud from a skylight in the roof of the inlet tube to the crater. Open cracks parallel northeast margin of subsidence bowl, and lobate ridges of thrust-fault origin (Swanson and Peterson, 1972) occur closer to center of bowl. Dark area in lower left is new collapse area referred to in text.

\section{FEBRUARY 21-JUNE 14, 1971}

The crust of the Alae lava lake began to subside soon after surface inflow ended (fig. 45). As Swanson and Peterson (1972, p. 11) summarized:

The lake crust had already subsided a maximum of $8 \mathrm{~m}$ by February 23 , when the crater was visited on the ground. We presume that the subsidence began somewhat earlier, probably on February 21. By February 26, the crust had lowered $17 \mathrm{~m}$, and most of the surface structures [cracks, thrust faults, and sinuous compressional ridges at the toes of thrust faults] related to subsidence had already formed. Deformation was largely complete by March 2, when the subsidence bowl was about $19 \mathrm{~m}$ deep. *** Slow settling of the crust continued over the next several months, amounting to an additional $4 \mathrm{~m}$ by June $28 * * *$

Swanson and Peterson (1972) further described the results of this subsidence, which included observing an active thrust fault, and interpreted the subsidence to have developed as

the pre-February lake crust sank into the molten lake because of the weight of new overlying flows. This subsidence displaced underlying molten lava upward and out of the lake through the outlet tube. The elevation of the base of the crust after both draining events [August 1970 and February-March 1971] was controlled in a crudely hydrostatic fashion by the elevation of the outlet tube.

Meanwhile, lava continued to pour from the inlet tube through the molten part of the lake and out the outlet tube during and after the crustal subsidence.
On February 22, lava once again flowed over Poliokeawe and Holei Palis, pooled at the base of Holei Pali, and began sending narrow fingers seaward. By February 26, the flow crossed the Chain of Craters Road above Kealakomo Pali (pl. 3M), and another 2$\mathrm{km}$ section of the road was covered by March 20 .

On March 5, the slowly advancing pahoehoe entered the abandoned Hawaiian village Kealakomo (pl. $3 M$ ), burying noted archeologic sites. On March 8, the tube-fed pahoehoe reached the ocean and began forming a delta, the development of which was described in detail by Moore, Phillips, Grigg, Peterson, and Swanson (1973) and Peterson (1976). Four days later, its area above sea level was about $2.5 \times 10^{4} \mathrm{~m}^{2}$, and by the time lava visibly stopped entering the sea on May 14, the delta was $4.7 \times 10^{5} \mathrm{~m}^{2}$ in area, extended more than $400 \mathrm{~m}$ seaward from the old coastline, and had a volume of more than $13.5 \times 10^{6} \mathrm{~m}^{3}$ (Peterson, 1976). Lava may have continued to flow into the sea through submerged tubes until at least May 25, as suggested by glowing cracks and persistent areas of steaming, very hot rock at the surface. Moreover, lava was seen flowing in the outlet tube from Alae as late as early June. The period of 82 days (February 22 to May 14) during which the tube-fed pahoehoe was definitely active constitutes the longest period of continuous flow during the eruption.

The trench on the east flank of Mauna Ulu continued to enlarge as its unstable walls, consisting of thin, highly jointed flows, repeatedly gave way. By March 20 , the chasm was $350 \mathrm{~m}$ long, $35-45 \mathrm{~m}$ wide, and from $15 \mathrm{~m}$ to $50 \mathrm{~m}$ deep. The trench grew rapidly westward, toward the summit crater. On March 23, the distance between the trench and crater was $50 \mathrm{~m}(\mathrm{pl} .4 N)$, on March 28, $13 \mathrm{~m}$, and on April 6, $3 \mathrm{~m} \mathrm{(pl.} \mathrm{4O).} \mathrm{The} \mathrm{up-}$ per part of the trench and crater merged on April 13 (pl. $4 P$ ), but a septum of wallrock capped by collapse debris to within $15 \mathrm{~m}$ of the ground surface separated the deeper parts, preventing the lava lake in the summit crater from draining into the trench. Rubble continued to slough off the septum, which by April 20 had lowered to $30 \mathrm{~m}$ below the rim, where it more or less stabilized. By this time, the trench had lengthened to about $430 \mathrm{~m}$ and widened to from $40 \mathrm{~m}$ to $60 \mathrm{~m}$; it reached its maximum length of $530 \mathrm{~m}$ by June 1 (pl. $4 P$ and fig. 46).

The floor of the trench through this period was mostly covered by rubble (fig. 47). Bubbling and gurgling noises were frequently heard and strong heat waves seen from several places along the trench east of vent 3 . Consequently, we assume that vent 3 was erupting and that other vents along the trench may also have been active during this period. In places, small pools of lava collected in low areas on the floor, 


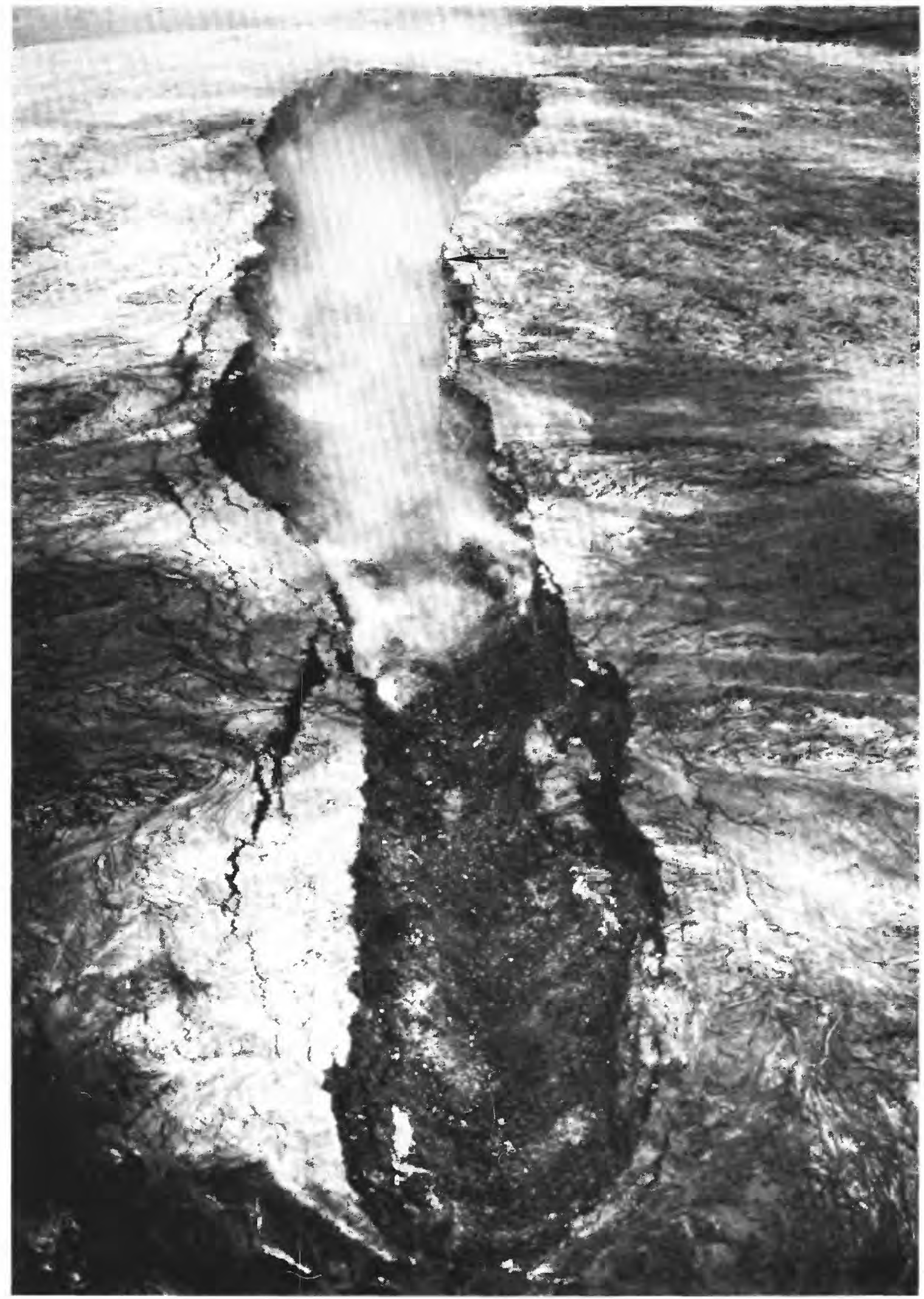

FIGURE 46.-Aerial view looking west over trench, with summit crater of Mauna Ulu in background, May 25, 1971. Jagged pile of rubble (arrow) separating trench from crater barely visible through fume. Cracks bound incipient slump blocks. Trench is about $530 \mathrm{~m}$ long from east end to rubbly partition. 


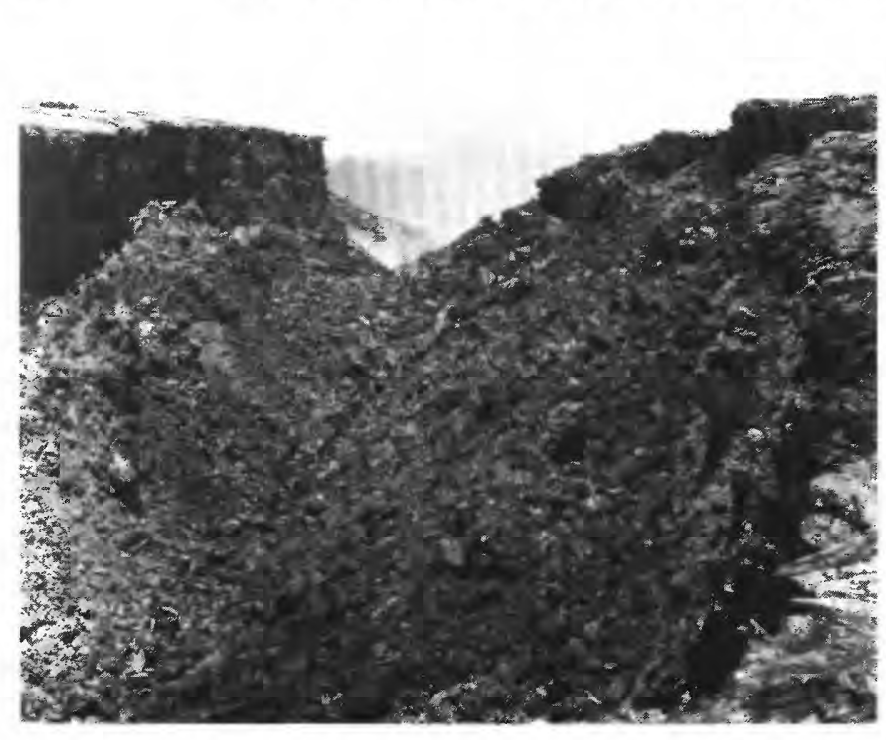

FIGURE 47.-View looking west from near east end of trench, June 28,1971 . Note rubble-strewn floor, tilted remnants of pretrench ground surface (upper right), and V-shaped profile. Fume obscures trench in distance. Depth from rim on left to top of ridge of rubble, about $5 \mathrm{~m}$.

apparently when the level of the underground river rose for brief periods. Lava could be seen in a deep tube leaving the east end of the trench (fig. 48) and at a depth of several tens of meters through a fuming skylight in the inlet tube to Alae (fig. 45).

The lava lake in the summit crater continued its typical activity, described for this period of time by Duffield (1972). By early April, the crater was oval shaped, $165 \mathrm{~m}$ by $100 \mathrm{~m}$ at the widest point (pl. 4O). Lake level remained $40-50 \mathrm{~m}$ below the rim through April, then began to lower gradually to $57 \mathrm{~m}$ by June 14 (fig. 7). Fuming increased as the level dropped, making observations of the lake very difficult.

An especially noteworthy collapse was observed at 2018, March 28. This collapse was so large that it registered on all seismometers within a $25-\mathrm{km}$ radius. Prior to the collapse, the lake was fountaining at the east end of the crater. Suddenly, a block at least $40 \mathrm{~m}$ long by $15 \mathrm{~m}$ wide fell from the northeast wall, tearing a wide hole through the crust. The entire surface of the lake reacted immediately, vigorously degassing and fountaining, and the level dropped about $10 \mathrm{~m}$ in a few seconds, despite the addition of the block. The drop in level was probably caused by loss of gas, facilitated by destruction of the crust that normally kept the gas from escaping. The new lake level, lower than at any previous time, revealed a stream of lava pouring into the lake from an elevated area hidden within the south side of the septum between the crater and trench. Both the stream and the lake itself were draining into a sump at the east end of the crater. We could not determine if the stream drained a perched pond within the septum, was produced by a separate vent, or flowed into the crater from the trench. Subsequent observations made when lake level was low before the end of the eruption suggest a perched pond connected to the main body of the lake. The level gradually rose after the dramatic withdrawal. By 2045 the lake had regained half the drop and covered the stream, and by 2100 the level was within 3-4 $\mathrm{m}$ of its former position.

\section{FOURTH STAGE OF ERUPTION}

\section{JUNE 15-OCTOBER 15, 1971}

The eruption slowly waned and finally ended during this period. No surface flows were erupted, and all activity was concentrated in the summit lake, which lowered at a remarkably constant rate of $70 \mathrm{~cm} /$ day (fig. 7), dropping from $60 \mathrm{~m}$ to $140 \mathrm{~m}$ below the rim by September 20 (fig. 49). Lava disappeared from sight on October 15, leaving a crater about $145 \mathrm{~m}$ deep with a rubble-strewn floor. This disappearance is arbitrarily taken as the end of the 1969-71 Mauna Ulu eruption.

The nature of activity in the lake changed when the level began its steady decline. In early June, the lake underwent minor rises and falls of 3-4 m amplitude superimposed on a slow but continuous circulation pattern from west to east, and fountaining a few meters high was common, especially around the east periphery of the lake. On about June 15, when lake level began to recede, the rate of circulation became more sluggish, the frequency and intensity of fountaining diminished, and the amplitude of the pistonlike action decreased to only a meter or so. The lake sometimes stagnated for a few minutes, and plates of crust foundered as is common in other stagnant lava lakes (see, for example, Wright and others, 1968, p. 3,197; Shaw and others, 1971, p. 878).

A flat-topped ridge $6-10 \mathrm{~m}$ wide, dividing the lake into two separate pools, was uncovered on July 17 , when lake level stood at $87 \mathrm{~m}$ below the rim (fig. 50). The two pools behaved independently, suggesting that each was fed by a separate vent which may be the same as those that supplied the eastern and western compartments of the old western vent area between August 20 and December 31, 1969. On July 19, the ridge stood well above the $95-\mathrm{m}$-deep pools. On July 20 , however, the ridge had sunk to about the same level as the pools, presumably because lateral support had been removed when the pools receded, thereby allowing the semisolid material of the ridge to subside and creep outward under the influence of gravity. A lava-filled channel crossed the northern part of the ridge, connecting the two pools. Both pools continued 


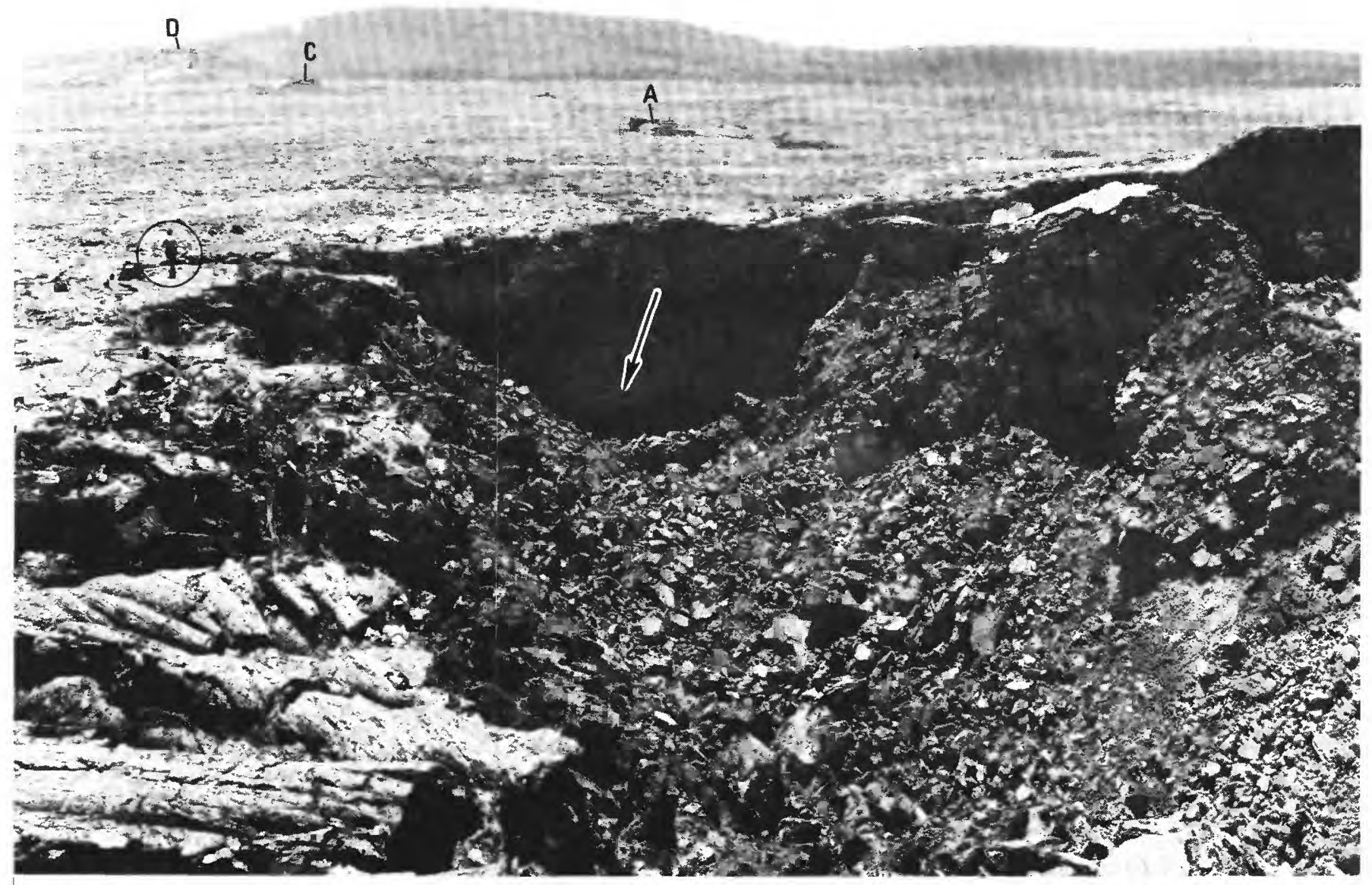

FIGURE 48.-Blunt east end of trench, June 28, 1971. Entrance to Alae inlet tube shown by arrow. Kane Nui o Hamo in background. Man (circled) gives scale. Cones of February 1969 eruption are indicated by letters used by Swanson, Jackson, Koyanagi, and Wright (1976).

to behave independently, and lava flowed east or west through the connecting channel depending on relative levels.

The dropping lake level also revealed a nearly vertical east-northeast-trending dike in the south side of the septum separating the crater and trench (fig. 51). This dike may have been injected on May 24, 1969, between the eastern and western vent areas. Its top, about $95 \mathrm{~m}$ below the rim, is about $15 \mathrm{~m}$ below ground level before the eruption.

The dominant direction of circulation in the pools remained eastward. With lowered lake level, we could see that the east wall of the crater was deeply undercut, as if it were the mouth of a tunnel (fig. 51). Lava tended to flow into this area and possibly into the trench although this was never confirmed.

Meanwhile, the level of the two pools continued to drop at about the same rate. This sinking, together with the accumulation of rubble from numerous rock falls, reduced the size of the pools to only a few meters across before they finally sank from sight on October 15. The separating ridge subsided at about the same rate as the pools, before becoming obliterated with talus in September.

According to our measurements, the level of the lake dropped below the preeruption ground surface, about $80 \mathrm{~m}$ below the rim of the crater, in early July (fig. 7). No evidence of this surface, such as a terrace, narrowing of the crater, or change in character of the wallrock lava flows, was revealed at this or any other stage of development of the crater. Whatever the crater-enlarging process was-stoping, thermal erosion, collapse, melting, or a combination of these-it was most efficient in tailoring the shape of the crater to a similar form throughout its depth.

\section{SIGNIFICANCE OF THE ERUPTION}

The 1969-71 Mauna Ulu eruption was the first of a series of eruptions, continuing until 1974, that stand unique in historically recorded accounts of Kilauea. For the first time in at least 150 years, flank activity on Kilauea continued for a period longer than a few weeks. The variety of behavior and persistence of events and processes allowed repeated and systematic 


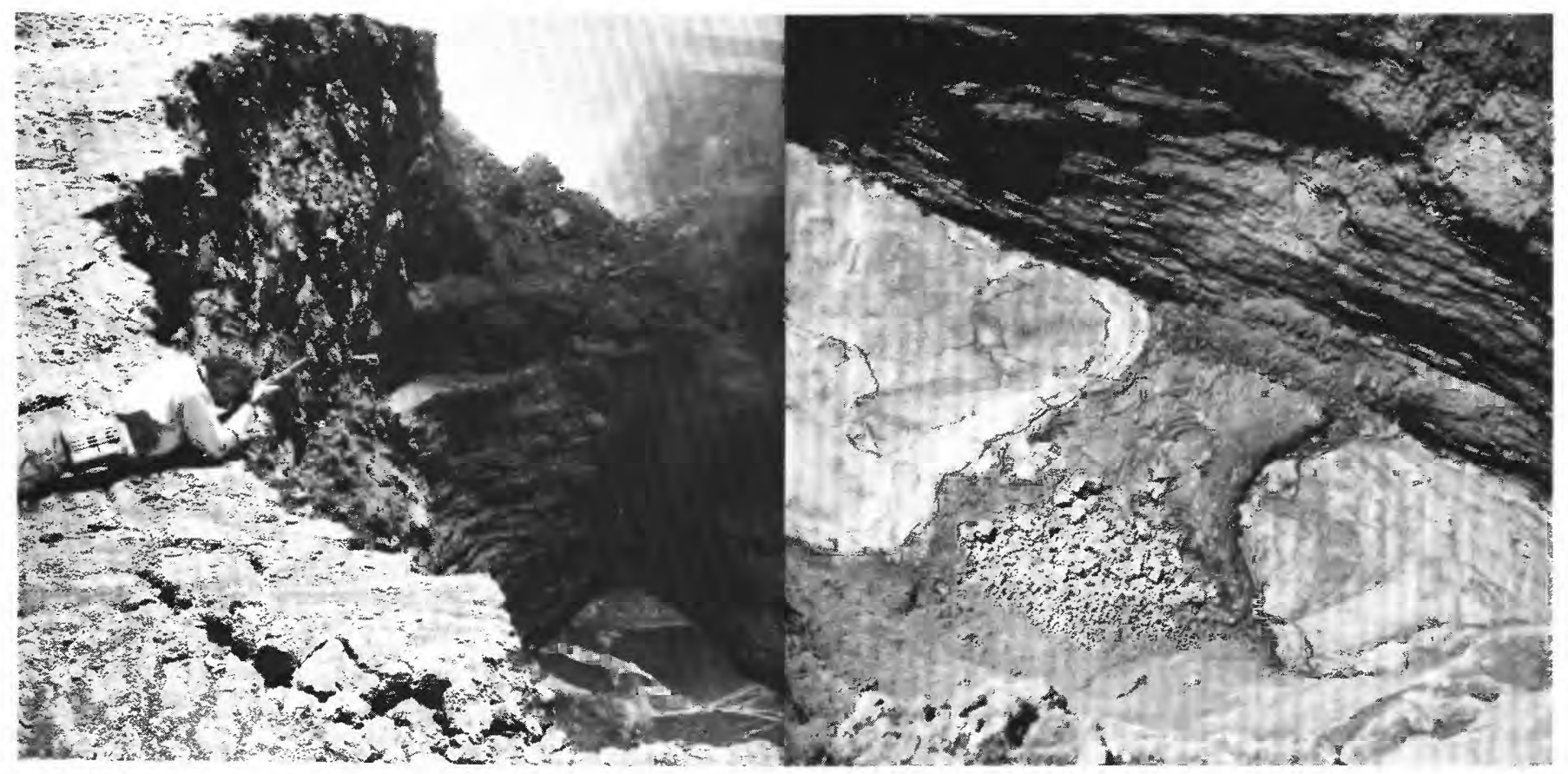

FIgURE 49.-Technique for measuring depth to surface of Mauna Ulu lava lake. Man sights with rangefinder to distinctive point on lake surface, and vertical angle to point is measured with clinometer. Depth is product of sine of angle and rangefinder distance. Repeated measurements to various points were averaged to reduce observational errors. Note the septum separating the east end of the crater from the fuming trench. July 1971.

observations, which have led to an improved understanding of the relations between the internal workings of the volcano and the eruptive behavior and processes of lava eruption and transport.

The eruption illustrated well the integrated system that constitutes a volcano in Hawaii, as seismicity and ground deformation in Kilauea's summit region were systematically correlated with the eruptive behavior of Mauna Ulu 8-9 km away. These correlations demonstrated that magma continually entered a shallow reservior of complex nature beneath Kilauea's summit at a rate of about $0.3 \times 10^{6} \mathrm{~m}^{3} /$ day. Ground deformation and seismic studies showed that the reservoir inflated when the rate of magma supply exceeded outflow, deflated when outflow exceeded supply, and remained in equilibrium when rates of supply and outflow were balanced.

The eruption displayed, for the first time historically, the development and sustained operation of an active lava lake at a locality other than Halemaumau at Kilauea's summit. The eruption revealed the significance of the gas-piston cyclic activity in the behavior of the lake and subsidiary vents. At times, gaspiston cycles dominated the eruptive behavior, and at other times they were secondary and subtle, but evidence of gas-piston action could be perceived in some
FIGURE 50.-Flat-topped ridge dividing lava lake into two pools, from north rim of Mauna Ulu crater. Note that east pool (left) is higher than west pool and encroaches on ridge. Depth to surface of east pool is $87 \mathrm{~m}$; ridge is $6-10 \mathrm{~m}$ wide. Photo taken on July 17 , 1971, the day ridge first appeared. Ledges on crater wall record past levels of lake surface.

degree during most of the eruption. This type of cycle may play an important role in the mechanism of eruption of basaltic lava, and its dynamics deserve further investigation.

The 1969-71 Mauna Ulu eruption also allowed, for the first time in recent history at Kilauea, repeated observations of prolonged lava flows. These observations led to new insights concerning the significance of several types of pahoehoe, the transition of pahoehoe to aa, the processes by which lava tubes develop, and the significance of prolonged flows in the development of certain landforms and in the major growth processes of basaltic islands.

The construction of a parasitic shield volcano was well exemplified by Mauna Ulu. Its growth was for the most part very rapid, particularly within one month in 1970 (though later eruptions in 1972-74 added further height to the edifice), and involved the relatively calm outflow of short-lived flows from the vent with little spatter activity. The apparently parental relation between the main vent of Mauna Ulu and vents on its west and east flanks suggests an analogy to the largerscale summit-rift systems of the principal Hawaiian shield volcanoes, and this analogy should be further examined.

To summarize, the 1969-71 Mauna Ulu eruption 
was, because of its long duration, unparalleled variety of activity, and easily accessible nature, one of the most significant eruptions ever at Kilauea. Informa- tion gathered during this immensely stimulating event will improve our knowledge of many important volcanic processes.

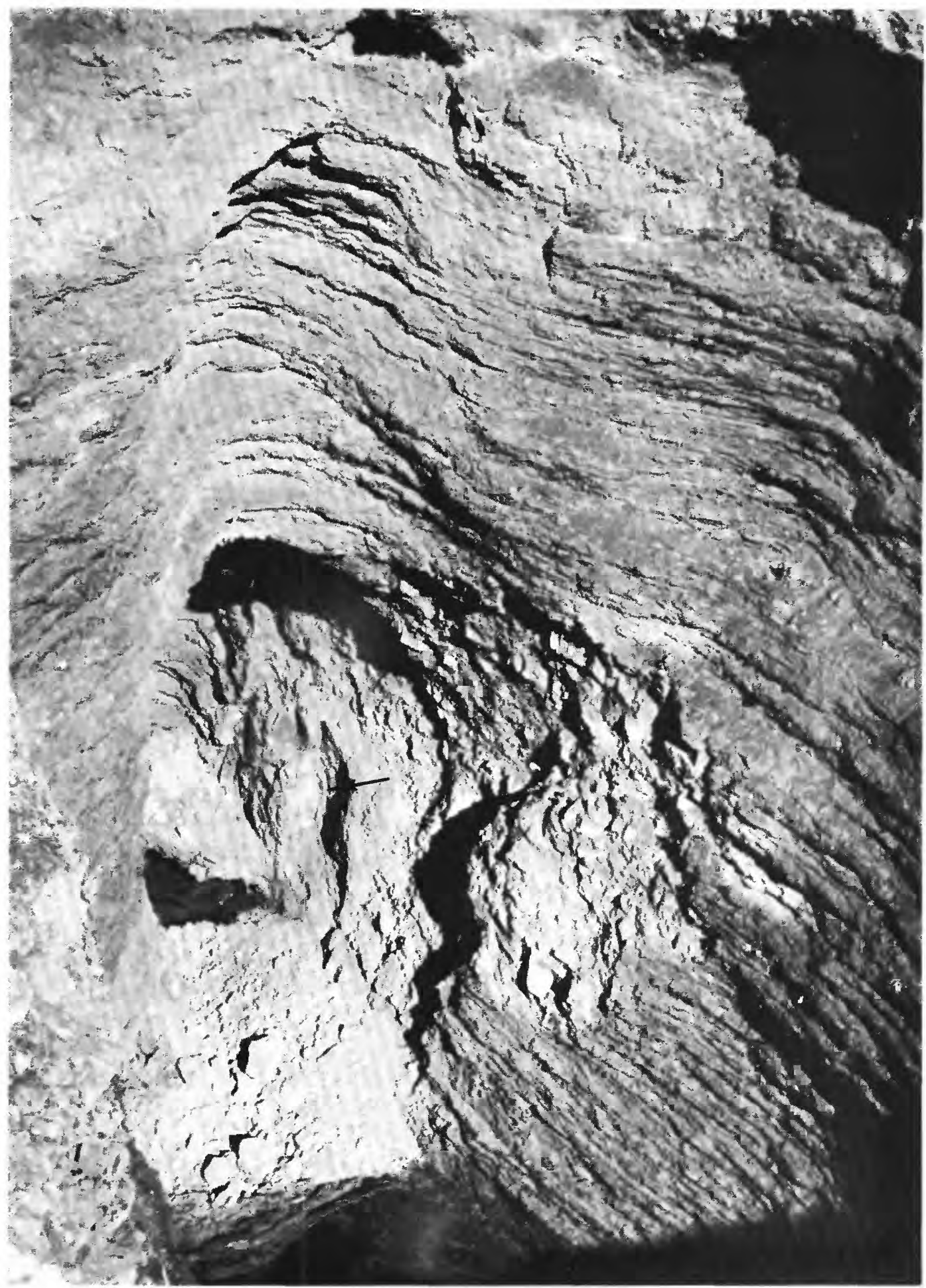

Figure 51.-East end of summit crater of Mauna Ulu, from north rim of crater, on September 7,1971 . Depth to floor about $123 \mathrm{~m}$. Alcove in septum between crater and trench contains small pool of crusted lava (dark). East edge of eastern pool in crater at bottom of view. Note dike (arrow). 


\section{REFERENCES CITED}

Anderson, L.A., Jackson, D.B., and Frischknecht, F.C., 1971, Kilauea Volcano: Detection of shallow magma bodies using the VLF and ELF induction methods: Am. Geophys. Union Trans., v. 52, no. 4 , p. 383.

Cristofolini, Renato, 1969, Alcuni aspetti dell'eruzione del Kilauea (Hawaii), nell'estate 1969 [in Italian with English summary]: Boll. Sedute dell'Accad. Gioenia di Science nat. Catania, ser. 4, v. 10, p. 1-32.

Cruikshank, D.P., and Wood, C.A., 1972, Lunar rilles and Hawaiian volcanic features: Possible analogues: The Moon, v. 3, p. 412-447.

Cruikshank, D.P., Morrison, David, and Lennon, Kenneth, 1973, Volcanic gases: Hydrogen burning at Kilauea Volcano, Hawaii: Science, v. 182, p. 277-279.

Davis, P.M., Jackson, D.B., Field, James, and Stacey, F.D., 1973, Kilauea Volcano, Hawaii: A search for the volcanomagnetic effect: Science, v. 180 , p. $73-74$.

Duffield, W.A., 1972, A naturally occurring model of global plate tectonics: 'Jour. Geophys. Research, v. 77, p. 2543-2555.

1975, Structure and origin of the Koae fault system, Kilauea Volcano, Hawaii: U.S. Geol. Survey Prof. Paper 856, 12 p.

Duffield, W.A., Heiken, Grant, and Gibson, E.K., Jr., 1974, Some physical and chemical characteristics of Pele's hair: Geol. Soc. America Abst. with Prog., v. 6, no. 3, p. 167-168.

Duffield, W.A., Jackson, D.B., and Swanson, D.A., 1976, The shallow, forceful intrusion of magma and related ground deformation at Kilauea Volcano, May 15-16, 1970: Inter. Assoc. Volcanology and Chemistry of Earth's Interior, Symp. Andean and Antarctic Volcanology Problems, Proceedings, p. 577-597.

Endo, E.T., 1971, Focal mechanism for the May 15-18, 1970, shallow Kilauea earthquake swarm: San Jose State Col., San Jose, Calif., M.S. thesis, 165 p.

Fiske, R.S., and Koyanagi, R.Y., 1968, The December 1965 eruption of Kilauea Volcano, Hawaii: U.S. Geol. Survey Prof. Paper $607,21 \mathrm{p}$.

Greeley, Ronald, 1971, Observations of actively forming lava tubes and associated structures, Hawaii: Modern Geology, v. 2, p. 207-223.

1972, Additional observations of actively forming lava tubes and associated structures, Hawaii: Modern Geology, v. 3, p. $157-160$.

Holcomb, R.T., 1976, Preliminary map showing products of eruptions, 1962-1974, from the upper east rift zone of Kilauea Volcano, Hawaii: U.S. Geol. Survey Misc. Field Inv. Map MF_811, scale $1: 24,000$.

Holcomb, R.T., Peterson, D.W., and Tilling, R.I., 1974, Recent landforms at Kilauea Volcano, a selected photographic compilation, in Greeley, R., ed., Hawaiian Planetology Conference, NASA TMX 62362, Washington, D.C., p. 49-86.

Jackson, D.B., Swanson, D.A. Koyanagi, R.Y., and Wright, T.L., 1975, The August and October 1968 east rift eruptions of Kilauea Volcano, Hawaii: U.S. Geol. Survey Prof. Paper 890, $33 \mathrm{p}$.

Kinoshita, W.T., Koyanagi, R.Y., Wright, T.L., and Fiske, R.S., 1969, Kilauea Volcano: The 1967-1968 summit eruption: Science, v. 166 , p. $459-468$.

Moore, J.G., and Koyanagi, R.Y., 1969, The October 1963 eruption of Kilauea Volcano, Hawaii: U.S. Geol. Survey Prof. Paper 614-C, $13 \mathrm{p}$.

Moore, J.G., and Krivoy, H.L., 1964, The 1962 flank eruption of Kilauea Volcano and structure of the east rift zone: Jour. Geophys. Research, v. 69, p. 2033-2045.
Moore, J.G., Phillips, R.L., Grigg, R.W., Peterson, D.W., and Swanson, D.A., 1973, Flow of lava into the sea, 1969-1971, Kilauea Volcano, Hawaii: Geol. Soc. America Bull., v. 84, p. 537-546.

Muenow, D.W., 1973, High temperature mass spectrometric gasrelease studies of Hawaiian volcanic glass-Pele's Tears: Geochim. Cosmochim. Acta, v. 37, p. 1551-1561.

Naughton, J.J., 1973, Volcanic flame: Source of fuel and relation to volcanic gas-lava equilibrium: Geochim. Cosmochim. Acta, v. 37, p. $1163-1169$.

Naughton J.J., Greenberg, V.A., and Goguel, R., 1976, Incrustations and fumarolic condensates at Kilauea Volcano, Hawaii: Field, drill-hole and laboratory observations: Jour. Volcanol. Geothermal Research, v. 1, p. 149-165.

Naughton, J.J., Lee, J.H., Keeling, Diana, Finlayson, J.B., and Dority, Guy, 1973, Helium flux from the earth's mantle as estimated from Hawaiian fumarolic degassing: Science, v. 180, p. 55-57.

Naughton, J.J., Lewis, V.A., Hammond, D., and Nishimoto, D., 1974, The chemistry of sublimates collected directly from lava fountains at Kilauea Volcano, Hawaii: Geochim. Cosmochim. Acta, v. 38, p. $1679-1690$.

Peck, D.L., Wright, T.L., and Moore, J.G., 1966, Crystallization of tholeiitic basalt in Alae lava lake, Hawaii: Bull. Volcanol., v. 29 , p. 629-656.

Peterson, D.W., 1976, Processes of volcanic island growth, Kilauea Volcano, Hawaii, 1969-1973: Inter. Assoc. Volcanology and Chemistry of Earth's Interior, Symp. Andean and Antarctic Volcanology Problems, Proceedings, p. 172-189.

Peterson, D.W., Christiansen, R.L., Duffield, W.A., Holcomb, R.T., and Tilling, R.I., 1976, Recent activity of Kilauea Volcano, Hawaii: Inter. Assoc. Volcanology and Chemistry of Earth's Interior, Symp. Andean and Antarctic Volcanology Problems, Proceedings, p. 646-656.

Peterson, D.W., and Swanson, D.A., 1974, Observed formation of lava tubes during 1970-1971 at Kilauea Volcano, Hawaii: Studies in Speleology, v. 2, p. 209-222.

Richter, D.H., Ault, W.U., Eaton, J.P., and Moore, J.G., 1964, The 1961 eruption of Kilauea Volcano, Hawaii: U.S. Geol. Survey Prof. Paper 474-D, p. Dl-D34.

Richter, D.H., and Moore, J.G., 1966, Petrology of the Kilauea Iki lava lake, Hawaii: U.S. Geol. Survey Prof. Paper 537-B, 26 p.

Schmincke, H.-U., 1971, Lavaströme auf Hawaii: Umschau, v. 71, p. 424-425.

Shaw, H.R., Kistler, R.W., and Evernden, J.F., 1971, Sierra Nevada plutonic cycle: Part II, tidal energy and a hypothesis for orogenic-epeirogenic periodicities: Geol. Soc. America Bull., v. 82, p. 869-896.

Shaw, H.R., and Swanson, D.A., 1970, Eruption and flow rates of flood basalts, in Gilmour, E.H., and Stradling, Dale, eds., Proceedings of the Second Columbia River Basalt Symposium: Cheney, Eastern Washington State Coll. Press, p. 271-299.

Swanson, D.A., 1972, Magma supply rate at Kilauea Volcano, 1952-1971: Science, v. 175, p. 169-170.

1973, Pahoehoe flows from the 1969-1971 Mauna Ulu eruption, Kilauea Volcano, Hawaii: Geol. Soc. America Bull., v. 84, p. 615-626.

Swanson, D.A., Duffield, W.A., and Fiske, R.S., 1976, Displacement of the south flank of Kilauea Volcano: The result of forceful intrusion of magma into the rift zones: U.S. Geol. Survey Prof. Paper 963, 39 p.

Swanson, D.A., Duffield, W.A., Jackson, D.B., and Peterson, D.W., 1972, The complex filling of Alae Crater, Kilauea Volcano, Hawaii: Bull. Volcanol., v. 36, p. 105-126. 
Swanson, D.A., and Fabbi, B.P., 1973, Loss of volatiles during fountaining and flowage of basaltic lava at Kilauea Volcano, Hawaii: Jour. Research U.S. Geol. Survey, v. 1, p. 649-658.

Swanson, D.A., Jackson, D.B., Duffield, W.A., and Peterson, D.W., 1971, Mauna Ulu eruption, Kilauea Volcano: Geotimes, v. 16, no. 5, p. $12-16$.

Swanson, D.A., Jackson, D.B., Koyanagi, R.Y., and Wright, T.L., 1976, The February 1969 east rift eruption of Kilauea Volcano, Hawaii: U.S. Geol. Survey Prof. Paper 891, 30 p.

Swanson, D.A., and Peterson, D.W., 1972, Partial draining and crustal subsidence of Alae lava lake, Kilauea Volcano, Hawaii, in Geological Survey research 1972: U.S. Geol. Survey Prof. Paper 800-C, p. C1-C14.

Walker, G.P.L., 1972, Compound and simple lava flows and flood basalts: Bull. Volcanol., v. 35, p. 579-590.
1973, Lengths of lava flows: Royal Soc. [London] Philos. Trans. A, v. 274, p. 107-118.

Wentworth, C.K., and Macdonald, G.A., 1953, Structures and forms of basaltic rocks in Hawaii: U.S. Geol. Survey Bull. 994, $98 \mathrm{p}$.

Whitford-Stark, J.L., and Wilson, L., 1976, Atmospheric motions produced by hot lava: Weather, v. 31, p. 25-27.

Wright, T.L., 1971, Chemistry of Kilauea and Mauna Loa in space and time: U.S. Geol. Survey Prof. Paper 735, 40 p.

Wright, T.L., Kinoshita, W.T., and Peck, D.L., 1968, March 1965 eruption of Kilauea Volcano and the formation of Makaopuhi lava lake: Jour. Geophys. Research, v. 73, p. 3181-3205.

Wright, T.L., Swanson, D.A., and Duffield, W.A., 1975, Chemical compositions of Kilauea east-rift lava, 1968-1971: Jour. Petrology, v. 16, p. 110-133. 